\title{
ALLELOPATHIC EFFECTS AND REMOVAL OF OVERSEEDED RYEGRASS \\ ON \\ BERMUDAGRASS
}

\begin{abstract}
A Dissertation
presented to

the Faculty of the Graduate School

University of Missouri

In Partial Fulfillment

of the Requirements for the Degree

Doctor of Philosophy

by

Brad S. Fresenburg

Dr. Reid J. Smeda, Dissertation Supervisor
\end{abstract}

December 2010 
The undersigned, appointed by the Dean of the Graduate School, have examined the dissertation entitled

\section{ALLELOPATHIC EFFECTS AND REMOVAL OF OVERSEEDED RYEGRASS \\ ON \\ BERMUDAGRASS}

Presented by Brad S. Fresenburg

a candidate for the degree of Doctor of Philosophy and hereby certify that in their opinion it is worthy of acceptance.

Dr. Reid Smeda

Dr. David Sleper

Dr. Dale Blevins

Dr. Robert Kremer

Dr. Mark Ellersieck 


\section{DEDICATION}

... To my wife, Carolyn, and our three children - Katherine, Kimberly, and

Michael for your inspiration and support. It is far greater than the gratitude and love I can give in return.

$$
\text { Your loving husband and dad }
$$

... To my mom and dad, for teaching me the value of commitment, hard work, and how to achieve my goals. Thanks for all that you taught me.

$$
\text { Your loving son }
$$




\section{ACKNOWLEDGEMENTS}

This dissertation would not have been possible without the support of all in the Division of Plant Sciences, MU Extension, and the Missouri Turf \& Ornamental Council. My thanks go out to you all.

A special acknowledgement goes to my advisor, Dr. Reid Smeda for his understanding, support, and friendship. Your knowledge and dedication to teaching is at the top.

I wish to acknowledge the remainder of my committee: Dr. David Sleper, Dr. Dale Blevins, Dr. Robert Kremer, and Dr. Mark Ellersieck. Thanks for all your support and patience. I wish to give acknowledgement and thanks to Dr. Chung-Ho Lin for all his assistance in the USDA ARS Cropping Systems \& Water Quality Lab. I wish to give a special acknowledgement and thanks to Kenton Binkholder for his assistance in the lab and in many areas of my daily work. 


\section{TABLE OF CONTENTS}

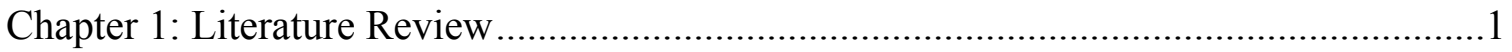

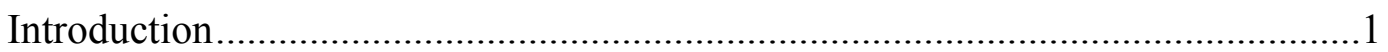

Transition Zone

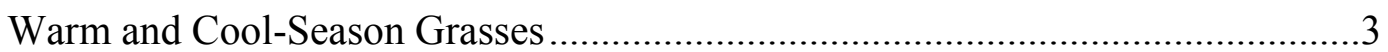

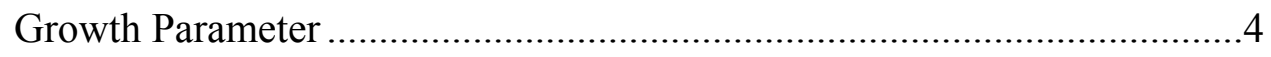

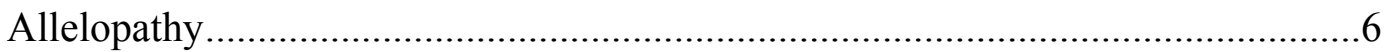

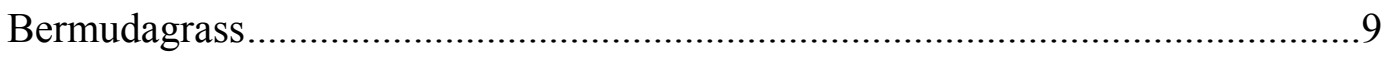

History

Usage

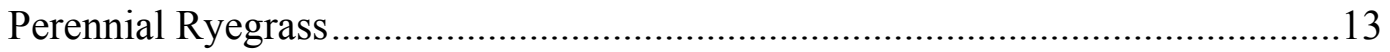

History

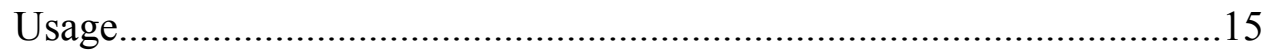

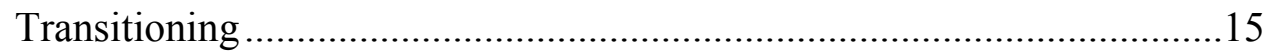

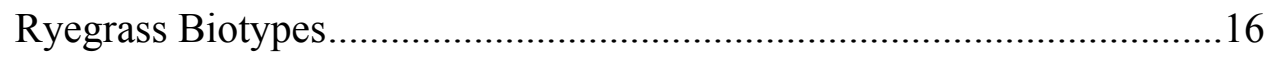

Perennial Ryegrass Over-seeding in Bermudagrass ............................................17

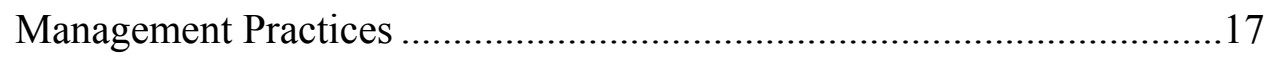

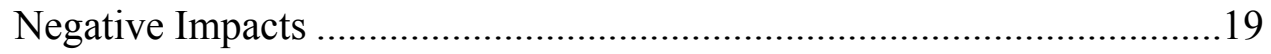

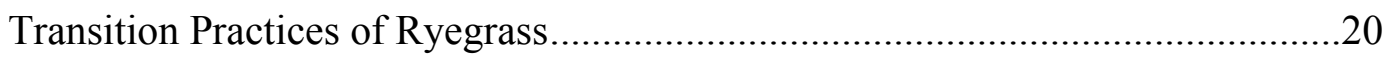

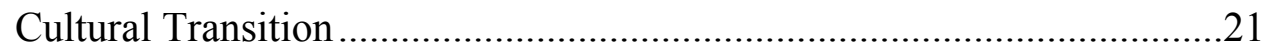

Chemical Transition .......................................................................22

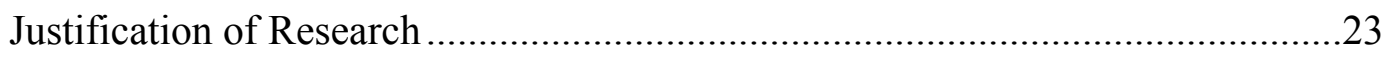


Techniques and Procedures

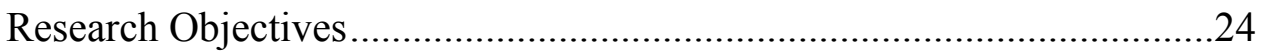

Specific Objectives ..................................................................24

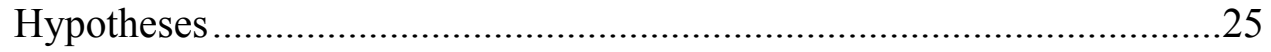

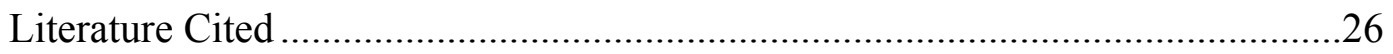

Chapter 2: Allelopathic Activity of Intermediate and Perennial Ryegrasses on

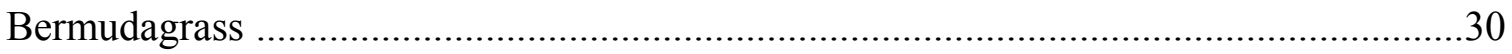

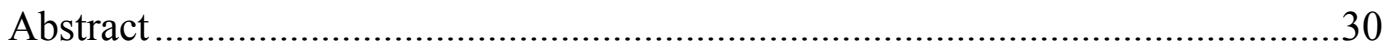

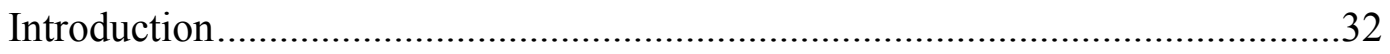

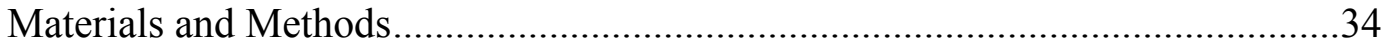

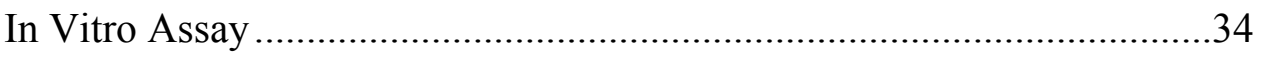

Fractionation of Allelopathic Compounds.........................................37

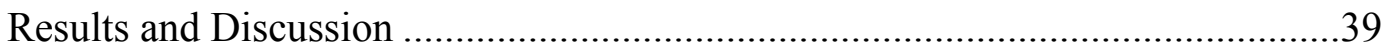

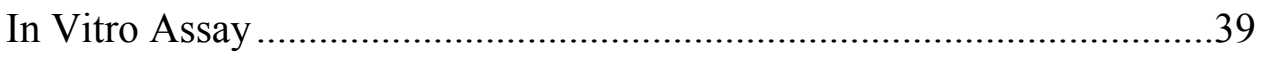

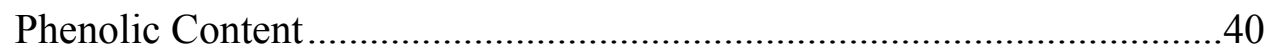

Fractionation Bioassays ..........................................................4

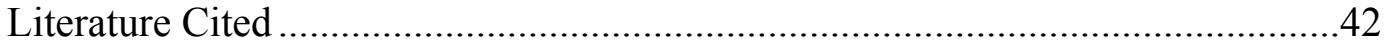

Chapter 3: Spring Removal of Intermediate and Perennial Ryegrass from Bermudagrass

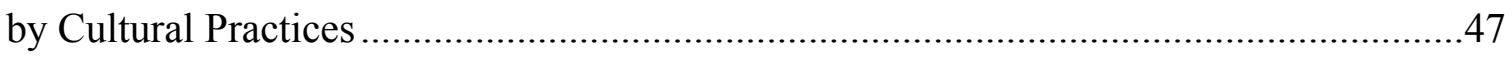

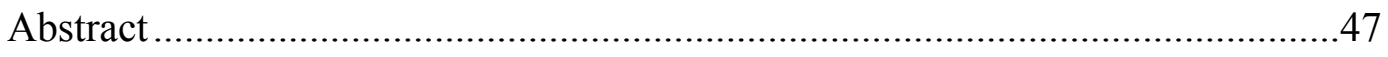

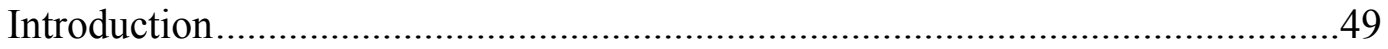


Materials and Methods.

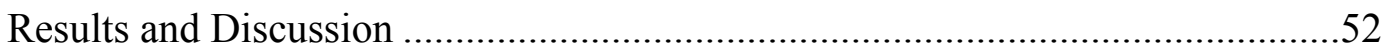

'Brightstar II' Perennial Ryegrass .....................................................52

'Transeze’ Intermediate Ryegrass..................................................54

Literature Cited .................................................................................. 57

Chapter 4: Spring Removal of Intermediate and Perennial Ryegrass from Bermudagrass

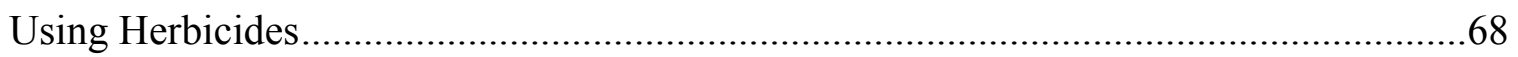

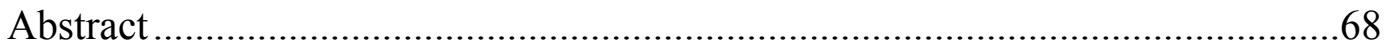

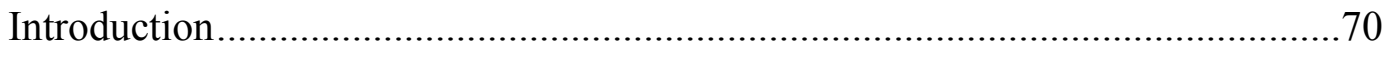

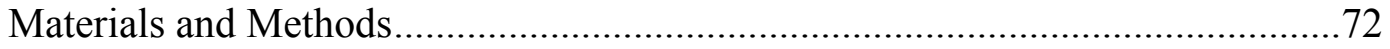

Results and Discussion ..................................................................... 74

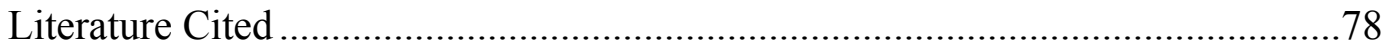

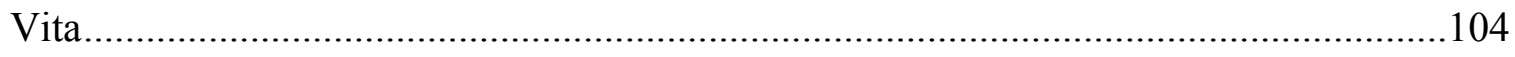




\section{LIST OF TABLES}

Chapter 2:

2-1 Bermudagrass germination ${ }^{\text {a }}$ from in vitro bioassays using ryegrass extracts from 'Brightstar II', 'Evening Shade', and 'Transeze' ryegrass cultivars. Results were combined over two trials (May, August, 2007).

2-2 Phenolic concentrations ${ }^{\mathrm{a}}$ in shoot and root extracts from 'Brightstar II', 'Evening Shade', and 'Transeze' ryegrass cultivars. Results were combined over two trials (May, August, 2007).

2-3 HPLC fractions of perennial and intermediate ryegrass root extracts showing bioassay activity on bermudagrass seed germination, fungal growth or both. Results were combined over two trials (August, 2009)

Chapter 4:

4-1 Herbicide names and rates (2006, 2007, and 2008). .80

4-2 Effect of herbicide applications on 'Brightstar II' perennial ryegrass and bermudagrass densities with resultant open space. Results were combined over three years, (Columbia, MO - 2006, 2007, 2008).

4-3 Effect of herbicide applications on 'Evening Shade' perennial ryegrass and bermudagrass densities with resultant open space. Results were combined over three years, (Columbia, MO - 2006, 2007, 2008)...

4-4 Effect of herbicide applications on 'Transeze' intermediate ryegrass and bermudagrass densities with resultant open space. Results were combined over three years, (Columbia, MO - 2006, 2007, 2008).

4-5 Effect of herbicide applications on 'QuickTrans' intermediate ryegrass and bermudagrass densities with resultant open space. Results were combined over three years, (Columbia, MO - 2006, 2007, 2008).

4-6 Transitional quality ${ }^{\mathrm{a}}$ based on presence of 'Brightstar II' perennial ryegrass, bermudagrass, and open space. Results were combined over three years (Columbia, MO - 2006, 2007, 2008).

4-7 Transitional quality ${ }^{\mathrm{a}}$ based on presence of 'Evening Shade' perennial ryegrass, bermudagrass, and open space. Results were combined over three years (Columbia, MO - 2006, 2007, 2008). 
4-8 Transitional quality ${ }^{\mathrm{a}}$ based on presence of 'Transeze' intermediate ryegrass, bermudagrass, and lack of open space. Results were combined over three years (Columbia, MO - 2006, 2007, 2008).

4-9 Transitional quality ${ }^{\mathrm{a}}$ based on presence of 'QuickTrans' intermediate ryegrass, bermudagrass, and open space. Results were combined over three years (Columbia, MO - 2006, 2007, 2008).

4-10 One-hundred day recovery date for bermudagrass prior to light and killing frost dates, Columbia, MO (2006, 2007, and 2008)... .89 


\section{LIST OF FIGURES}

Chapter 3:

3-1 Removal of 'Brightstar II' perennial ryegrass from bermudagrass by mowing and application of urea fertilizer. Results were combined over three years (Columbia, $\mathrm{MO}$ -

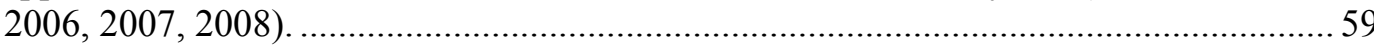

3-2 Removal of 'Transeze' perennial ryegrass from bermudagrass by mowing and application of urea fertilizer. Results were combined over three years (Columbia, $\mathrm{MO}-$ 2006, 2007, 2008).

3-3 Bermudagrass recovery after removal of 'Brightstar II' perennial ryegrass by mowing and application of urea fertilizer. Results were combined over three years (Columbia, MO - 2006, 2007, 2008).

3-4 Bermudagrass recovery after removal of 'Transeze' perennial ryegrass by mowing and application of urea fertilizer. Results were combined over three years (Columbia, MO 2006, 2007, 2008).

3-5 Open space during removal of 'Brightstar II' perennial ryegrass from bermudagrass by mowing and application of urea fertilizer. Results were combined over three years (Columbia, MO - 2006, 2007, 2008)

3-6 Open space during removal of 'Transeze' perennial ryegrass from bermudagrass by mowing and application of urea fertilizer. Results were combined over three years (Columbia, MO - 2006, 2007, 2008)

3-7 Transitional quality during removal of 'Brightstar II' perennial ryegrass from bermudagrass by mowing and application of urea fertilizer. Results were combined over three years (Columbia, MO - 2006, 2007, 2008).

3-8 Transitional quality during removal of 'Transeze' perennial ryegrass from bermudagrass by mowing and application of urea fertilizer. Results were combined over three years (Columbia, MO - 2006, 2007, 2008)

3-9 Average maximum daily temperature during spring transition in Columbia, MO over three years $(2006,2007$, and 2008).

Chapter 4:

4-1 Removal of over-seeded 'Brightstar II' perennial ryegrass from bermudagrass treated with sulfonylurea herbicides. Results were combined over three years (Columbia, MO 2006, 2007, 2008). Mean differences were determined using Fisher's Least Significant Difference (LSD) at the 0.05 level of probability. 909

4-2 Removal of over-seeded 'Evening Shade' perennial ryegrass from bermudagrass treated with sulfonylurea herbicides. Results were combined over three years (Columbia, MO - 
2006, 2007, 2008). Mean differences were determined using Fisher's Least Significant Difference (LSD) at the 0.05 level of probability.

4-3 Removal of over-seeded 'Transeze' intermediate ryegrass from bermudagrass treated with sulfonylurea herbicides. Results were combined over three years (Columbia, MO 2006, 2007, 2008). Mean differences were determined using Fisher's Least Significant Difference (LSD) at the 0.05 level of probability.

4-4 Removal of over-seeded 'QuickTrans' intermediate ryegrass from bermudagrass treated with sulfonylurea herbicides. Results were combined over three years (Columbia, MO 2006, 2007, 2008). Mean differences were determined using Fisher's Least Significant Difference (LSD) at the 0.05 level of probability. 93

4-5 Bermudagrass recovery after removal of over-seeded 'Brightstar II' perennial ryegrass treated with sulfonylurea herbicides. Results were combined over three years (Columbia, MO - 2006, 2007, 2008). Mean differences were determined using Fisher's Least Significant Difference (LSD) at the 0.05 level of probability. 94

4-6 Bermudagrass recovery after removal of over-seeded 'Evening Shade' perennial ryegrass treated with sulfonylurea herbicides. Results were combined over three years (Columbia, MO - 2006, 2007, 2008). Mean differences were determined using Fisher's Least Significant Difference (LSD) at the 0.05 level of probability. 95

4-7 Bermudagrass recovery after removal of over-seeded 'Transeze' intermediate ryegrass treated with sulfonylurea herbicides. Results were combined over three years (Columbia, MO - 2006, 2007, 2008). Mean differences were determined using Fisher's Least Significant Difference (LSD) at the 0.05 level of probability. 96

4-8 Bermudagrass recovery after removal of over-seeded 'QuickTrans' intermediate ryegrass treated with sulfonylurea herbicides. Results were combined over three years (Columbia, MO - 2006, 2007, 2008). Mean differences were determined using Fisher's Least Significant Difference (LSD) at the 0.05 level of probability.

4-9 Open space created by removal of over-seeded 'Brightstar II' perennial ryegrass from bermudagrass with sulfonylurea herbicides. Results were combined over three years (Columbia, MO - 2006, 2007, 2008). Mean differences were determined using Fisher's Least Significant Difference (LSD) at the 0.05 level of probability.

4-10 Open space created by removal of over-seeded 'Evening Shade' perennial ryegrass from bermudagrass with sulfonylurea herbicides. Results were combined over three years (Columbia, MO - 2006, 2007, 2008). Mean differences were determined using Fisher's Least Significant Difference (LSD) at the 0.05 level of probability.

4-11 Open space created by removal of over-seeded 'Transeze' intermediate ryegrass from bermudagrass with sulfonylurea herbicides. Results were combined over three years (Columbia, MO - 2006, 2007, 2008). Mean differences were determined using Fisher's Least Significant Difference (LSD) at the 0.05 level of probability. 100

4-12 Open space created by removal of over-seeded 'QuickTrans' intermediate ryegrass from bermudagrass with sulfonylurea herbicides. Results were combined over three years 
(Columbia, MO - 2006, 2007, 2008). Mean differences were determined using Fisher's Least Significant Difference (LSD) at the 0.05 level of probability.

4-13 Average maximum daily temperatures during spring transition in Columbia, MO.

4-14 Average soil temperatures at $10 \mathrm{~cm}$ in Columbia, MO during spring transition indicating when soil temperatures where consistently above $16.5 \mathrm{C}$ (vertical line). 


\section{CHAPTER 1}

\section{LITERATURE REVIEW}

\section{Introduction}

Over-seeding bermudagrass (Cynodon spp.) with perennial ryegrass (Lolium perenne) has become a common cultural practice in southern golf courses and athletic fields. Breeding additional cold tolerant cultivars of bermudagrass has driven this cultural practice farther north into the Transition Zone of the United States.

The practice of over-seeding perennial ryegrass in the South creates competition for bermudagrass. However the desire for green, lush fairways and athletic fields outweighs the concerns of superintendents and groundskeepers over thin bermudagrass during spring transition. Longer, warmer growing seasons in the South are sufficient for rapid recovery of the bermudagrass sward.

In more northern areas (Transition Zone), groundskeepers are more concerned over thin bermudagrass in spring transition due to a shorter growing season, limiting recovery. Perennial ryegrass may interfere with bermudagrass re-growth by simple competition or additionally through the release of allelochemicals that suppress bermudagrass development. Turf managers must minimize the impact of perennial ryegrass to optimize bermudagrass cover in the spring.

Investigations of allelopathic effects of perennial ryegrass on bermudagrass begin with some background knowledge about the Transition Zone, warm-season and cool-season grasses, and allelopathy. Reference to these terms throughout this dissertation will add clarity to the discussion and aid the explanation of why certain cultural practices have been recommended throughout the history and development of bermudagrass usage on 
golf courses and athletic fields. This discussion will also detail the cultural practices used presently to over-seed perennial ryegrass in bermudagrass and later remove the ryegrass.

\section{Transition Zone}

The Transition Zone in the United States covers a 300 to 700 mile-wide transect latitudinally across the United States. The zone lays between the northern cool, humid region where cool-season turfgrass species are naturally adapted, and the southern warm, humid region, where warm-season turfgrass species are adapted. Much of the northern edge of this zone is roughly defined from east to west by Interstate 70 from Maryland to eastern Kansas. The southern edge transects through parts of Virginia, North Carolina, Tennessee, and Arkansas, following along latitude of $36^{\circ}$ north. Within this zone, neither warm- nor cool-season grass species are completely adapted (Dunn and Diesburg, 2004)

Bevard (2004) stated the Transition Zone refers to the climatic region where both cool- and warm-season turfgrasses can be grown. Turgeon (2002) defined the transitional climatic zone as the "sub-optimal zone" between temperate and sub-tropical climates. There are periods when weather extremes in the Transition Zone provide challenges for the management of both cool- and warm-season grasses. Extremely cold winters or prolonged periods of ice cover can promote winter-kill of warm-season grasses; hot, humid summers induce tremendous stress for cool-season grasses such as perennial ryegrass. 


\section{Warm- and Cool-Season Grasses}

Adaptation of turfgrasses refers to changes or adjustments to environmental conditions, and may require breeding to promote survival (McCarty and Miller, 2002). Minor adjustments in physiological processes will allow plants to survive a wide range of climatic conditions. McCarty and Miller (2002) cite differences in both geological and morphological characteristics between warm and cool-season grasses; the most important difference occurs in the physiology of these plants. The adaptation of some grass plants, for example bentgrass (Agrostis spp.), to cooler climates was not fully understood until the Calvin-Benson $\left(\mathrm{C}_{3}\right)$ and the Hatch and Slack $\left(\mathrm{C}_{4}\right)$ cycles (carbon fixation cycles) for warm-season grasses were discovered in the 1950s and 1960s, respectively (McCarty and Miller, 2002).

Photosynthesis is the process by which light energy is converted into usable chemical energy as carbohydrates. Prior to 1965, it was understood that a three-carbon compound, 3-phosphoglyceric acid (or 3-PGA) was the first product of carbon fixation in coolseason or $\mathrm{C}_{3}$ plants (Taiz and Zeiger, 2006). A four-carbon compound, oxaloacetic acid (OAA) was the first product formed in warm-season or $\mathrm{C}_{4}$ plants (McCarty and Miller, 2002; Taiz and Zeiger, 2006), hence the derived connotation of $\mathrm{C}_{3}$ or $\mathrm{C}_{4}$ plants when referring to the carbon cycles of plants.

During hot and dry conditions, cool-season grasses close stomata to prevent excessive water loss and continued fixation of carbon in the Calvin cycle greatly reduces $\mathrm{CO}_{2}$ concentrations in the chloroplast. Photosynthetic activity suffers because of photorespiration, the reversal of fixing carbon. A catalyst called rubisco begins to fix oxygen instead of carbon reducing its efficiency to $25 \%$ (Taiz and Zeiger, 2006). Warm- 
season plants overcome this problem by having a two stage system (Kranz's anatomy) that keeps $\mathrm{CO}_{2}$ levels high and oxygen levels low in the chloroplast where the Calvin cycles functions (Taiz and Zeiger, 2006). This is why cool-season plants like ryegrass suffer during late spring and summer. McCarty and Miller (2002) explained that the existence of two different carbon fixation mechanisms provided an understanding of inherent differences between certain plants and has allowed golf course superintendents to manipulate microenvironments. The result is growth of certain species outside their naturally adapted areas.

Most $\mathrm{C}_{4}$ plants are grasses (monocots), and evolved in sub-tropical climates characterized by high air temperatures and high light intensities (greater than 13 hours of solar radiation $)$. Warm-season turfgrass species $\left(\mathrm{C}_{4}\right.$ cycle $)$ include: bermudagrass, zoysiagrass (Zoysia spp.), buffalograss (Buchloe dactyloides), bahiagrass (Paspalum notatum), carpetgrass (Axonopus spp.), centipedegrass (Eremochloa ophiuroides), kikuyagrass (Pennisetum clandestinum), seashore paspalum (Paspalum vaginatum), and St. Augustinegrass (Stenotaphrum secundatum). For optimum carbon fixation, coolseason turfgrass species $\left(\mathrm{C}_{3}\right.$ cycle $)$, require only half the light intensity compared to warm-season grasses, and include: fescues (Festuca spp.), bluegrasses (Poa spp.), ryegrasses (Lolium spp.), and bentgrasses (Agrostis spp.).

\section{Growth Parameters}

Golf course superintendents and athletic field groundskeepers are well aware of the role that weather plays in the success or failure of over-seeding perennial ryegrass onto bermudagrass. Dry and/or cool weather conditions can result in poor, fall establishment of perennial ryegrass as well as a difficult spring transition to bermudagrass. 
A turf growth model illustrating the role that weather plays in the growth of both warm-season and cool-season turf was presented by Gelernter and Stowell (2005) to aid turf managers in coping with the effects of weather on over-seeding management plans. When the growth potential of either a cool-season or warm-season turf is $100 \%$, that turf has reached its optimal growth because temperatures are ideal for the particular turf species. Turf growth is still favorable below the $100 \%$ level, as long as growth potential is above $50 \%$. Therefore, the turf growth potential model is based upon the interaction of weather (primarily temperature for this model) and turf performance (growth potential). Beard (2002) specified optimum temperatures which are required for both warm- and cool-season turfgrasses. Cool-season turf grows best with air temperatures at 15.5 to 23.8 $\mathrm{C}(60$ to $75 \mathrm{~F})$, with growth decreasing at temperatures greater than $26.6 \mathrm{C}(80 \mathrm{~F})$ and below $10 \mathrm{C}(50 \mathrm{~F})$ (Beard, 2002). Warm-season turf growth is optimal at 26.6 to $35 \mathrm{C}$ (80 to $95 \mathrm{~F}$ ), with growth decreasing (onset of dormancy) at temperatures less than 12.7 C (55 F) (Beard, 2002).

Gelernter and Stowell (2005) conducted research similar to Beard (2002), and confirmed that cool-season turf reaches $100 \%$ of the plant's growth potential when average air temperatures are $20 \mathrm{C}(68 \mathrm{~F})$. For air temperatures above or below $20 \mathrm{C}$, growth potential decreases. Warm-season turf growth follows a similar pattern, but temperatures for optimal growth are much higher (31 C; 88 F) (Gelernter and Stowell, 2005). When temperatures are cooler or warmer than $31 \mathrm{C}$, growth potential decreases. Gelernter and Stowell (2005) state that use of these data can explain why cool and warm-season turfgrasses perform poorly (slow growth), demonstrating how unexpected weather patterns can influence turf growth and quality. Turfgrass managers can apply the 
research of Gelernter and Stowell (2005) to determine: 1) the optimal turfgrass specie for a region; 2) whether over-seeding a warm-season turfgrass with a cool-season turfgrass is appropriate; 3) the optimal over-seeding date; and 4) the optimum time to apply sulfonylurea herbicides for removing over-seeded turfgrass species in the spring.

\begin{abstract}
Allelopathy
References to allelopathy utilize numerous terms: chemical toxicity, auto-toxicity, detrimental effect, allelochemical, and interference among organisms (harmful or beneficial). The word "allelopathy" is derived from two separate words; allelon which means "of each other", and pathos which means "to suffer". A commonly accepted definition of allelopathy is the chemical inhibition of one species by another (Putnam and Tang, 1986; Rivenshield, 2006). The "inhibitory" chemical is released into the environment by the donor plant where it affects the development and growth of neighboring plants, seeds, plant pathogens, insects, etc.

The history of allelopathy began with Theophrastus (ca. 300 B.C.) who noted that chickpea (Cicer arietinum) "exhausts" the ground and destroys weeds and "above all and soonest caltrop" (Tribulus terristris) (Rice, 1984). In 1 A.D., Gaius Plinius Secundus, also known as Pliny the Elder, a roman scholar and naturalist, wrote about how chickpea and barley (Hordeum vulgare) "scorch up" corn land (Rice, 1984). He also mentioned that walnut (Juglans spp.) trees are toxic to other plants. Augustin Pyramus De Candolle (1832), a botanist and naturalist, suggested that soil sickness was caused by chemicals released by the plant. From 1907 to 1909, two researchers, Schreiner and Reed (1907a, 1907b) investigated the isolation of a number of phytotoxic chemicals from plants and
\end{abstract}


soils. However, it was not until the mid-twentieth century that allelopathy had been studied in both field and laboratory research.

McCollum (2002) defined allelopathy as the study of harmful and beneficial effects of a plant on another by means of chemicals. He also stated that allelochemicals function in four general categories: allomones, kairomones, synomones, and antimones. These chemicals can be released into the environment by a number of processes such as: leaching from above ground plant parts, root exudation, stem flow, volatilization, microbial activity, decomposition of plant residues, insect frass, and the plowing of plant residues (living and dead) into the soil (Putnam and Tang, 1986).

Rye (Secale cereal L.) produces dense canopies that compete with weeds for light, water, and nutrients (Rice, 1984). Additionally, rye residues lying on the soil surface will reduce weed seed germination by serving as mulch, lowering soil temperatures, and creating a physical barrier (Barnes and Putnam, 1986; Rice, 1984). Rye residues left on the soil surface will also leach phytotoxins into the soil, inhibiting weed germination and seedling growth (Barnes et al., 1987).

Rye has been studied due to its weed suppressant properties. Rye residues release 2, 4-dihydroxy-1,4(2H0-benzoxazin-3-one (DIBOA) and a secondary product 2(3H)benzoxazalinone (BOA) (Barnes and Putnam, 1987). Additional experiments have displayed reductions in agronomic weed germination of barnyardgrass (Echinochloa crusgalli L.), common lambsquarters (Chenopodium album L.), common ragweed (Ambrosia artemisiifolia L.), green foxtail [(Setaria viridis (L.) Beauv.], and redroot pigweed (Amaranthus retroflexus L.) (Putnam and DeFrank, 1983; Shilling et al., 1985) 
King (1996) demonstrated the effects of twelve perennial ryegrass cultivars on crabgrass (Digitaria spp.) suppression in bermudagrass. His work concentrated on Acremonium endophyte infection of perennial ryegrass, contained in ryegrasses at various levels ( 0 to 97 percent infection), which he described as having strong allelopathic effects on crabgrass in a ryegrass extract-agar-crabgrass seed bioassay. Higher levels of endophyte infection in perennial ryegrasses reduced crabgrass seed germination (25 to 30\%). However, King (1996) did report some inconsistencies among the various cultivars of perennial ryegrass.

Putnam and Tang (1986) and Coder (1999) pointed out that secondary plant metabolites may function as allelochemicals. Terpenoids, phenolics, alkaloids, cyanohydrins, isothiocyanates, nitriles, and polyacetylenes are widely recognized as an integral part of the plant's defense mechanism (Harborne, 1982). Distinct differences between primary and secondary metabolites include solubility. Primary metabolites, except for long-chain fatty acids and esters, are hydrophilic compounds. Secondary metabolites are usually hydrophobic or partially hydrophobic (Putnam and Tang, 1986). Therefore, secondary metabolites can be separated from primary metabolites using a column of hydrophobic resin (Amberlite XAD-4 - Rohm \& Haas Company, Philadelphia, PA) (Putnam and Tang, 1986).

Plant root systems exhibit extremely large surface areas for the uptake of water and nutrients. In turn, substantial quantities of exudates can be widely released from the roots. Many reports indicate that "root exudates" are collected for assessments of allelopathic potential (Putnam and Tang, 1986). However, caution is needed in the interpretation of results, since the identification of allelochemicals in root exudates 
remains a challenge. In an experimental process, any physical disturbance that could damage root structure releases intracellular contents, contaminating root exudates (Ayers and Thornton, 1968).

Allelopathy is a complex phenomenon involving a variety of interrelationships among plants (Kohli, 1998). When organisms compete with one another, they create the potential for resource limitations. Allelopathic plants prevent other plants from using the available resources and thus influence the evolution and distribution of other species. One might say that allelopathic plants control the environments in which they live.

\section{Bermudagrass}

Bermudagrass is a long-lived perennial grass originating along the Indian Ocean, and ranging from eastern Africa to the East Indies (McCarty and Miller, 2002). Plants are adapted to sub-humid, open, closely grazed rangelands characterized by hot, dry summers.

History

Bermudagrass was introduced into the United States from Africa by 1751 (Hanson, 1972). Carolina farmers of the 1700 's preferred it as forage, calling it "crop grass or crab grass (Syntherisma spp.)", according to Drayton's View of South Carolina (Gray, 1958). Bermudagrass quickly spread throughout the southeast during the late eighteenth century and early nineteenth century, thus becoming a significant southern forage grass (Dunn and Diesburg, 2004). Bermudagrass was planted on golf courses (Carrier, 1927) and lawns (Enlow and Stokes, 1929) in Florida by the 1920's. Early golf course superintendents appreciated the heat and drought tolerance of bermudagrass, which meant that the turf required little or no irrigation during summer (Dunn and Diesburg, 
2004). The fine-leaved texture of bermudagrass was recognized as an advantage for use in lawns, but intolerance to shade was also noted (Enlow and Stokes, 1929). Homeowners discovered that bermudagrass was a desirable grass in southern lawns even if it was coarse and cold hardiness (tolerance) was unpredictable (Dunn and Diesburg, 2004).

In 1947, the United States Golf Association, in cooperation with the United States Department of Agriculture, released 'U-3' bermudagrass (Dunn and Diesburg, 2004). This new bermudagrass cultivar became widely used because of its so-called "improved" leaf texture and winter hardiness. However, drawbacks included winter injury during severe winters, and a high susceptibility to spring dead spot disease (Ophiosphaerella spp.). Today, ' $\mathrm{U}-3$ ' is considered a common bermudagrass and still persists in some southern fairways and sports turf venues.

Ralph Sehrt discovered 'Westwood' bermudagrass in the 1960s on a fairway at the Westwood Country Club in St. Louis, Missouri. The origin of "Westwood' is uncertain, although some have suggested that it may have originated as a mutation of ' $U-3$ ' (Dunn and Diesburg, 2004). A primary advantage of 'Westwood' over 'U-3' was its higher tolerance to spring dead spot disease. Continued improvements in bermudagrass have resulted in the release of new cultivars. Ray Keen and his successors at Kansas State University released two bermudagrass cultivars, 'Midway' and 'Midiron', in the 1960s. 'Midlawn' and 'Midfield' were released in cooperation with Oklahoma State University and the Kansas Turfgrass Foundation in the 1970s (Dunn and Diesburg, 2004). Occurring about the same time, Glenn Burton of Tifton, Georgia, released a number of the 'Tif' cultivars of bermudagrass (i.e. 'Tifgreen' \& 'Tiflawn'). Many of these 'Tif' 
cultivars are in use in the golf course and recreational turf markets (Dunn and Diesburg, 2004).

Eight species of Cynodon are recognized, of which turf types are included only in the $2 n=36$ C. dactylon (L.0 Pers. Var. dactylon ("Common bermudagrass"), the $2 n=18$ C. transvaalensis Burtt-Davy ("African bermudagrass"), and their $2 \mathrm{n}=27$ interspecific hybrid C. X magenissi Hurcombe (= C. dactylon X C. transvaalensis) (Harlan et al., 1970). C. transvaalensis strains have a finer texture and exhibit less cold hardiness. Interspecific hybrids are sterile and produce little or no seed with coarse leaf textures and greater cold hardiness.

Throughout the 1990s, breeding emphasis with bermudagrass centered on the development of seeded cultivars. A relatively new technique for development of seedpropagated bermudagrasses is the breeding of intraspecific hybrids (Dunn and Diesburg, 2004). Both parents are from the same species, Cynodon dactylon. Intraspecific hybrids produce more viable seed than interspecific hybrids and several seeded cultivars became commercially available in the late 1990s ('Yukon', 'Riviera', 'Blackjack', 'Mirage', 'Princess 77', and 'Sun Devil'). However, many lack the cold hardiness required for the Transition Zone (Morris, 1997). While interspecific hybrids must be established vegetatively, several exhibit excellent cold hardiness and thrive in the Transition Zone ('Quickstand', 'Patriot', 'Cardinal', 'OKC 19-9', 'Midiron', and 'Midfield') (Morris, 2002; Dunn, et al., 2001). Seeded cultivars of bermudagrass that exhibit excellent cold hardiness include: 'Riviera', 'Guymon', and 'Yukon' (Dunn, et al., 2001). 


\section{$\underline{\text { Usage }}$}

Bermudagrass has numerous benefits in turf. Aggressive root systems minimize soil erosion, stabilize ditch banks, cover roadsides and airfields, and beautify landscapes, along with providing a smooth, resilient playing surface for sports fields and playgrounds (Duble, 2004). Bermudagrass also serves as a source of hay and pasture for livestock throughout the tropical and subtropical areas of the world.

Turf applications of common bermudagrass include sports fields, lawns, parks, playgrounds, golf course fairways, roadsides, cemeteries, and other general purpose turf. Selections of hybrid bermudagrass are used for sports fields, golf greens, bowling greens, tennis courts, croquet courts and lawns. Bermudagrass is popular in the Transition Zone and southern United States because it provides an excellent surface for golf (Patton, et al., 2004).

Several bermudagrass cultivars have been selected specifically for putting greens due to their tolerance for short mowing, fine-texture, higher shoot density, deeper roots, and less thatch development. They include: 'Tifgreen', 'Tifdwarf', 'Floradwarf', and 'TifEagle' (Turgeon, 2002; McCarty and Miller, 2002; Duble, 2004). Some of the "ultradwarf" selections of bermudagrass are also used for putting greens and lawn bowling and include: 'Champion', 'MS Supreme', 'MiniVerde', and 'Forida Dwarf' (McCarty and Miller, 2002). Other bermudagrass selections are better suited for golf course fairways: 'TifWay', 'Midway', 'Texturf 10', 'Texturf 1F', 'Ormond', and 'Tiflawn' (Turgeon, 2002; Duble, 2004).

Bermudagrass is well adapted to athletic fields because it has excellent wear tolerance (capability to withstand traffic and maintain cover) and recuperative ability (Patton, et al., 
2004). In fact, bermudagrass is considered the premier turfgrass for athletic fields in the southern United States (Patton et al, 2004). Patton et al. (2004) also stated that improvements in the cold tolerance of seeded and vegetative bermudagrass cultivars now allow this turfgrass to be used in southern Indiana. Patton indicates that 'Midlawn', 'Patriot', and 'Quickstand' (vegetative cultivars), along with 'Riviera' (seeded cultivar), were the best adapted bermudagrasses for Indiana athletic fields. In work conducted at the University of Missouri Turfgrass Research Facility, Dunn, et al. (2000) showed that 'Midlawn', 'Quickstand', and OKS 92-1 ('Riviera') were best adapted to mid-Missouri winters. Over two years, artificial freeze tests and field observations with "Quickstand' and 'Midlawn' showed survival following exposure to an average minimum freezing temperature of -10 C (14 F); OKS 95-1 ('Riviera') plants survived with an average minimum freezing temperature of $-7.7 \mathrm{C}(18 \mathrm{~F})$.

\section{Perennial Ryegrass}

\section{History}

Information on the history and development of perennial ryegrass appears limited considering the extensive use of perennial ryegrasses around the world and across the United States (Huebner, 2003). Ryegrasses originated in southern Europe, North Africa, and southwest Asia (Huebner, 2003). Perennial and annual ryegrasses are probably the most widely used of all grasses around the world for both forage and turf uses. Perennial ryegrass carpets large areas of the British Isles, and plants are extensive in parts of the northeastern and northwestern United States (Dunn and Diesburg, 2004). The early common types of perennial ryegrass played a role as a winter over-seeding material for 
southern warm-season grasses. In the north, perennial ryegrasses are considered as a starter grass to provide quick green cover and prevent soil erosion. However, the reliability of the common genetically diverse ryegrasses was poor, since plants are sensitive to summer diseases such as brown patch (Rhizoctonia solani) (Dunn and Diesburg, 2004).

Concerns with ryegrass reliability changed in 1967 with the release of 'Manhattan' perennial ryegrass by Reed Funk at Rutgers University (Dunn and Diesburg, 2004). Source material was collected in Manhattan's Central Park. 'Manhattan' ryegrass was characterized by tough leaf tissue (difficult to mow), which resisted wear (for use on athletic fields) better than other cool-season grasses. 'Pennfine' was released in 1969 from Penn State and exhibited superior mowing qualities compared to 'Manhattan' (Dunn and Diesburg, 2004).

With early cultivars, warm weather diseases in the Transition Zone dramatically reduced stands of perennial ryegrasses after four to five years. During the 1980s and 1990s, improved cultivars of perennial ryegrass were developed for heat tolerance and disease resistance. While most improved cultivars are more deeply rooted and recover rapidly from sport activities, they still have many short-comings compared to other coolseason grasses. Dunn and Diesburg (2004) stated that until breeding work leads to new cultivars with better summer characteristics (heat and drought tolerance), the best use for perennial ryegrass in the Transition Zone is for specialty purposes in sports and home lawn turf, over-seeding bermudagrass for winter cover, and rapid establishment and repair of damaged areas. Currently, there are 120 cultivars of perennial ryegrass being tested in the National Turfgrass Evaluation Program (NTEP) trials (Morris, 2004). 


\section{$\underline{\text { Usage }}$}

Perennial ryegrass is a cool-season grass that is used predominantly on sports fields, cricket pitches, and race courses in the USA, Europe, Japan, Australia, and New Zealand (Thorogood, 2003). Over-seeding is performed in late summer through early fall as bermudagrass growth ceases and plant tissue browns following exposure to extended periods below $10 \mathrm{C}(50 \mathrm{~F})$ (McCarty and Miller, 2002). Established perennial ryegrass adds green color to the turf containing bermudagrass. Autumn over-seeding of perennial ryegrass has become a common, cultural practice on sports grounds established with either couchgrass (Cynodon spp.) or kikuyugrass in regions subject to winter dormancy (Beehag, 2005). In addition, golf course fairways are also over-seeded to clearly mark suggested landing areas for golfers. Over-seeding is an important economic aspect of golf because many resort courses enjoy their heaviest play from tourists during the fall, winter, and spring months. Over-seeding also improves winter and spring playing conditions compared to playing on dormant bermudagrass (McCarty and Miller, 2002). Nearly all perennial ryegrass seed is used in the United States and Europe; the United States uses $64 \%$ of the total perennial ryegrass produced world-wide (Thorogood, 2003).

\section{Transitioning}

Spring transition is when the winter turfgrass (i.e. perennial ryegrass) is replaced by the summer turfgrass (i.e. bermudagrass) (Umeda and Towers, 2004). Transition is often referred to as a single transition associated with bermudagrass athletic fields (Askew, 2007). Askew (2007) pointed out that there are in fact two transitions, one in the spring and one in the fall. When over-seeding perennial ryegrass in the fall, fields are being 
transitioned from bermudagrass to perennial ryegrass. In the spring, elimination of the perennial ryegrass is the goal to preserve the health of the underlying bermudagrass.

The transition period from perennial ryegrass to bermudagrass in the spring is a critical time in managing over-seeded turfgrasses (Yelverton, 2004). Yelverton (2004) also stated that a timely transition is critical to ensure a healthy stand of bermudagrass, and failure to remove perennial ryegrass in a timely manner will ultimately reduce stands.

The key to spring transition is timely removal of perennial ryegrass, thereby allowing full bermudagrass recovery. Full recovery includes not only 100 percent ground cover, but also sufficient rhizome and stolon growth to provide surface strength (Yelverton, 2004). Previous research and observations indicate that bermudagrass needs approximately 100 days of growth (air temperatures above 29 C) to recover in the absence of perennial ryegrass competition (Yelverton, 2004 and 2005). Bermudagrass in Missouri can have up to 125 days of growth per season. Failure to remove perennial ryegrass in a timely manner can result in significant shading of the bermudagrass canopy and lead to substantial bermudagrass stand loss (Yelverton, 2005).

\section{Ryegrass Biotypes}

Annual ryegrass (Lolium multiforum Lam.) is a cool-season annual or short-lived perennial bunch-type grass that is sometimes referred to as annual Italian ryegrass (Lolium multiforum Lam.). Annual ryegrass forms a fine- to coarse-textured turf, depending upon seeding rate and final density. Annual ryegrass is widely used in subtropical climates for over-seeding dormant or semi-dormant warm-season turfs for winter sports and green color (Turgeon, 2002). It has been replaced partially by improved turftype perennial ryegrasses. 
Perennial ryegrass is sometimes referred to as perennial English ryegrass (Lolium perenne L.). It is a fine textured, moderately dark green grass with high density. It is also known as a "starter grass" because of its rapid germination (Turgeon, 2002). Perennial ryegrass provides excellent turf quality in the spring and fall, however it has poor heat and drought tolerance and is very susceptible to many spring and summer diseases.

"Intermediate" ryegrasses have been under evaluation for quality and transitional characteristics for several years, but are now receiving more consideration for overseeding bermudagrass athletic fields. Intermediate ryegrasses (Lolium multiforum Lam. $\mathrm{x}$ Lolium perenne L.) are interspecific hybrids of annual and perennial ryegrasses (Turgeon, 2002). Intermediate ryegrasses have the fine quality characteristics of a perennial ryegrass, but the behavioral characteristics of an annual ryegrass.

\section{Perennial Ryegrass Over-seeding in Bermudagrass}

\section{$\underline{\text { Management Practices }}$}

Over the past several decades, many recommendations have been made on the overseeding practices of perennial ryegrass in bermudagrass (McCarty and Miller, 2002). The combined species provide a year-round green turf surface and potentially provides greater attraction for fall, winter and early spring sports (McElroy, 2006).

Over-seeding is recommended for fields (athletic) which are used for both fall and spring seasons. The bermudagrass base is over-seeded in mid-September with a blend of perennial ryegrasses at a rate of $5.45 \mathrm{Kg}$ (12 pounds) of pure live seed (PLS) per 92.9 square meters ( 1,000 square feet). Over several weeks, an additional $1.36 \mathrm{Kg}$ ( 3 pounds) 
of seed is added to poorly established areas (Puhala et al., 1999). McCarty (2001) suggested golf course over-seeding rates of 11.3 to 18.2 ( 25 to 40 pounds), 6.8 to 9.1 (15 to 20 pounds), and 2.7 to 4.5 (6 to 10 pounds) kilograms of seed per 92.9 square meters (1,000 square feet) for greens, tees and fairways, respectively. Typical seeding rates for putting greens (bermudagrass), on a 92.9 square meter (1,000 square foot) basis, are 11 to $14 \mathrm{~kg}$ ( 22 to 28 pounds) of seed for perennial ryegrass, 4 to $5 \mathrm{~kg}$ ( 8 to 10 pounds) of seed for rough bluegrasses, 0.5 to $2 \mathrm{~kg}$ ( 1 to 4 pounds) of seed for bentgrasses, and 6 to $8 \mathrm{~kg}$ (12 to 16 pounds) of seed for fine fescues (Festuca spp.) (Beard, 2002).

Kopec et al. (2001) indicated that bermudagrass cover in plots did not increase as seeding rates of perennial ryegrass increased. Highest seeding rates $\left(898 \mathrm{~kg} \mathrm{ha}^{-1}\right)$ always produced the least bermudagrass cover, while the lowest over-seeding rates $\left(505 \mathrm{~kg} \mathrm{ha}^{-1}\right)$ produced the greatest amounts of bermudagrass cover. Over-seeding rates of 505 to 618 $\mathrm{kg} \mathrm{ha}^{-1}$ and from 673 to $786 \mathrm{~kg} \mathrm{ha}^{-1}$ provided the most complete transition and acceptable turf.

Mazur and Rice (1999) in South Carolina concluded that the choice of seeding rates of perennial ryegrass was a compromise between rapid development and quality cover versus early, smooth transition to bermudagrass in the spring. This work included overseeding rates ranging from 90 grams per square meter $\left(900 \mathrm{~kg} \mathrm{ha}^{-1}\right)$ to 180 grams per square meter $\left(1800 \mathrm{~kg} \mathrm{ha}^{-1}\right)$. Mazur and Rice (1999) suggested that 150 grams per square meter $\left(1,496 \mathrm{~kg} \mathrm{ha}^{-1}\right)$ may be the best choice for turf quality, but delays spring transition to bermudagrass. Rates used by Mazur and Rice (1999) exceeded the highest rates reported by Kopec et al., (2001) yet Mazur and Rice only reported delays in spring transition and not a lack of bermudagrass cover. 


\section{Negative Impacts}

Numerous cultivars of perennial ryegrass have been released and marketed since the 1960's, and these are far superior to older cultivars. Persistence of the improved perennial ryegrass cultivars during warm weather increases the potential for competition with bermudagrass. Over-seeding too early in the fall and allowing ryegrass to persist too late in the spring/summer contributes to a lack of recovery time for bermudagrass (Yelverton, 2005). If bermudagrass does not have sufficient time to grow during the summer without competition from perennial ryegrass (100 days), bermudagrass stands will decline over time, and sometimes result in total decline (Yelverton, 2005). This decline usually occurs over two or three years, but has been known to occur in one year. Yelverton (2005) stated that when bermudagrass initiates growth in spring, perennial ryegrass growth is at its maximum. As a result, the perennial ryegrass provides significant shade over the emerging bermudagrass. Duble (1996) stated that at low light intensities (less than $60 \%$ full sunlight), bermudagrass develops narrow and elongated leaves, thin upright stems, elongated internodes, and weak rhizomes. Beard (2002) describes bermudagrass adaptability to shade as poor.

Bermudagrass thinning is a culmination of several years of over-seeding perennial ryegrass and allowing stands to persist (Yelverton, 2005). Additionally, many of the newer perennial ryegrass cultivars are more heat tolerant and persist longer if not chemically removed (Yelverton, 2005). 


\section{Transition Practices of Ryegrass}

Golf course superintendents and sports turf managers have long known that spring transition of perennial ryegrass in bermudagrass was important. Early on, managers strictly relied upon cultural practices such as mowing, fertilizer and core aeration to remove perennial ryegrass (Beard, 2002; Horgan and Yelverton, 2001). Success of spring transition was also dependent upon spring weather (Beard, 2002; USGA Report, 2004). Cool weather favors perennial ryegrass, while warm/hot temperatures favor bermudagrass. Also, improved perennial ryegrass cultivars preclude complete transition when using cultural practices alone (Yelverton, 2005; Mazur, 1993). Yelverton (2005) also stated that, "one of the worst things that can happen is that only about $90 \%$ of the perennial ryegrass dies out. This will result in the remaining ryegrass becoming clumpy. Once perennial ryegrass becomes clumpy, it will not die out on its own."

Research has revealed the difficulty of transitioning perennial ryegrass. To improve this process, numerous sulfonylurea herbicides, which specifically inhibit the plastidic enzyme acetolactate synthase (ALS), were adopted (Ray, 1982). In recent years, sulfonylurea herbicides have efficiently removed perennial ryegrass in the spring without injury to bermudagrass (Umeda and Towers, 2004). Sulfonylurea herbicides like chlorsulfuron (Corsair ${ }^{\circledR}$ ) and metsulfuron (Manor ${ }^{\circledR} /$ Blade ${ }^{\circledR}$ ) were first introduced into small grains or non-crop situations. More recently registered sulfonylurea herbicides include rimsulfuron (TranXit $\left.{ }^{\circledR}\right)$, foramsulfuron $\left(\right.$ Revolver $\left.{ }^{\circledR}\right)$, trifloxysulfuron (Monument $\left.{ }^{\circledR}\right)$, and sulfosulfuron $\left(\right.$ Certainty $\left.{ }^{\circledR}\right)$. 


\section{$\underline{\text { Cultural Transition }}$}

As spring approaches, cultural practices can facilitate removal of ryegrass: increased fertility levels, lower mowing heights, lower grooming brushes, topdressing, and the use of other reel implements such as grooved rollers (McCarty, 2001). The following procedures have been proven beneficial by McCarty (2001) for encouraging bermudagrass rather than over-seeded grasses: 1) use the appropriate seed mixture (perennial ryegrass, roughstalk bluegrass or bentgrass) for over-seeding; 2) time the transition according to air temperatures (night temperatures consistently reach the mid60's); 3) reduce mowing height; 4) cultivate; 5) apply fertilizers; 6) vertical slicing; and 7) maintain adequate soil moisture.

Horgan and Yelverton (1998) outlined cultural methods for golf course superintendents because these practices are techniques for removing ryegrass. Those methods included: 1) lower the mowing height of perennial ryegrass and allowing light to penetrate the turf canopy; 2) vertical slicing to stimulate bermudagrass; 3 ) core cultivate to warm the soil and stimulate lateral growth of bermudagrass; 4) apply high rates of ammonium nitrate ( $0.9 \mathrm{~kg}$ per 92.9 square meters) to burn perennial ryegrass and deter growth; and 5) combine some or all of these cultural methods.

Beard (2002) stated that the approach most commonly used to minimize spring transition problems on southern bermudagrass putting greens is a combination of: (a) close mowing; (b) increased nitrogen fertility level; (c) weekly light vertical cuttings; and (d) turf cultivation by coring, while the cool-season grasses are actively growing. Beard (2002) indicated that the optimum timing for implementation of combined practices is prior to initiation of spring greenup of bermudagrass; this precludes spring root decline of 
the bermudagrass. Beard (2002) suggested the key biological indicator of consistent bermudagrass growth is a $10 \mathrm{~cm}(4 \mathrm{inch})$ soil temperature at $17 \mathrm{C}(62 \mathrm{~F})$.

\section{Chemical Transition}

Advantages in the use of herbicides compared to cultural practices include efficacy and control over precise timing for removal of the perennial ryegrass. McElroy (2006) stated that recently labeled sulfonylurea herbicides such as trifloxysulfuron (Monument ${ }^{\circledR}$ ) and foramsulfuron $\left(\right.$ Revolver $\left.^{\circledR}\right)$ can eliminate perennial ryegrass. Another advantage expressed by McElroy (2006) is that repeated applications of sulfonylureas at lower use rates (less than labeled rates) improve the potential for a seamless transition. This procedure removes perennial ryegrass slowly, matching the gradual greenup of bermudagrass.

Horgan and Yelverton (1998) reported that pronamide $\left(\operatorname{Kerb}^{\circledR}\right)$ was the best treatment for complete perennial ryegrass transition. However, approximately eight weeks was needed for effective control. To create a smooth transition with Kerb ${ }^{\circledR}$, applications should occur six to eight weeks before full bermudagrass green-up. The primary difference in herbicides that remove perennial ryegrass is the speed at which perennial ryegrass is removed. Yelverton (2005) presented a list of herbicides from slowest to fastest removal of perennial ryegrass: $\operatorname{Kerb}^{\circledR}$, Manor $^{\circledR} /$ Blade $^{\circledR}$, Revolver $^{\circledR}, \operatorname{TranXit}^{\circledR}$, and Monument ${ }^{\circledR}$. Umeda and Towers (2004) have described the most complete comparison of sulfonylurea herbicides for spring transition. Using seven sulfonylurea herbicides in six field experiments, flazasulfuron $\left(0.03 \& 0.06 \mathrm{~kg} \mathrm{ai} \mathrm{ha}^{-1}\right)$, foramsulfuron $(0.015 \& 0.03$ $\mathrm{kg}$ ai ha $\left.{ }^{-1}\right)$, rimsulfuron $\left(0.05 \& 0.11 \mathrm{~kg}\right.$ ai ha $\left.{ }^{-1}\right)$, trifloxysulfuron $(0.03,0.05 \& 0.16 \mathrm{~kg}$ ai $\left.\mathrm{ha}^{-1}\right)$, and chlorsulfuron $\left(0.05 \& 0.11 \mathrm{~kg}\right.$ ai ha $\left.{ }^{-1}\right)$ were effective in removing most of the 
perennial ryegrass. Sulfosulfuron $\left(0.04 \& 0.11 \mathrm{~kg}\right.$ ai ha $\left.{ }^{-1}\right)$ and metsulfuron $(0.005 \&$ $0.011 \mathrm{~kg}$ ai ha ${ }^{-1}$ ) were least effective in removing ryegrass.

\section{Justification of Research}

Bermudagrass is a warm-season perennial that turns straw colored with the onset of winter dormancy. Sports turf managers have traditionally over-seeded bermudagrass athletic fields with perennial ryegrass in the fall to maintain playability and aesthetics (green cover). Recommended over-seeding rates of perennial ryegrass (total from multiple applications) range from 5.45 to $9.1 \mathrm{~kg}$ per 92.9 square meters (12 to 20 pounds of seed per 1,000 square feet) throughout the fall (Puhala et al., 1999). Higher overseeding rates complicate complete spring transition, which leads to the persistence of ryegrass clumps (Yelverton, 2005). Continued use of this practice for two or three years greatly reduces the amount of bermudagrass present in athletic fields (Beard, 2002; Kopec, et al., 2001). Reductions in bermudagrass stands require significant investments per field (8547 square meters) in re-establishment by seed $(\$ 1500)$, sprigs $(\$ 4000)$, or sod $(\$ 24,000)$.

Concerning the transition of ryegrass in established bermudagrass, several questions can be asked: (i) Does ryegrass have an allelopathic effect on bermudagrass? (ii) Can a timely cultural practice (mowing height and urea fertilization) encourage spring transition of perennial ryegrass without impacting bermudagrass stands? (iii) Can a timely herbicide application improve spring transition of ryegrass and reduce the effect on bermudagrass stand reduction? (iv) Will the use of intermediate ryegrass reduce the negative effects on bermudagrass stands? 


\section{Techniques and procedures}

As I determine the optimum cultural and herbicide removal of over-seeded intermediate and perennial ryegrasses on bermudagrass, evaluations for bermudagrass recovery and ryegrass removal will be conducted at various observation dates during spring transition (green-up of bermudagrass and perennial ryegrass decline). A modification of the vertical point quadrant method (Zuk and Fry 2001; Laycock and Canaway 1980) will be used to determine species remaining within each treated plot to track progression of spring transition. The vertical point quadrant will be constructed of a PVC frame with an internal monofilament grid on $10 \mathrm{~cm}$ centers. The grid will be placed over each plot to estimate coverage in each treatment. The presence of any bermudagrass plant under an intersection will be recorded as a "hit." This same approach will be used to record a ryegrass plant or open space. To determine the percent coverage of each species and open space, the number of hits for each species or open space will be divided by the number of intersections on the grid. Quality ratings will be taken on a scale of one to nine, where nine equals ideal turf, six equals acceptable turf, and one will equal completely dead or dormant turf (Skogley and Sawyer 1992).

\section{$\underline{\text { Research objectives }}$}

The overall objective of this research is to assess inhibitory (allelopathic) activity on bermudagrass and determine optimum management practices for spring transition of fall over-seeded ryegrasses on bermudagrass.

\section{$\underline{\text { Specific objectives }}$}

I. To determine the impact of intermediate and perennial ryegrass on bermudagrass cover. 
II. To determine if production of allelopathic toxins inhibits bermudagrass.

III. To determine optimum spring transition of intermediate and perennial ryegrasses from bermudagrass through the use of cultural practices (three mowing heights with and without nitrogen fertilizer).

IV. To determine optimum spring transition of intermediate and perennial ryegrasses from bermudagrass through the use sulfonylurea herbicides.

\section{Hypotheses}

(i) There is no difference in percent bermudagrass germination following addition of allelopathic extracts of intermediate ryegrass stems/leaves and roots.

(ii) There is no difference in percent bermudagrass germination from allelopathic extracts of perennial ryegrass stems/leaves and roots.

(iii) There is no difference in percent cover of intermediate and perennial ryegrass transitioned (removed from bermudagrass while bermudagrass greens up in spring) to bermudagrass by close mowing and nitrogen fertilizer.

(iv) There is no difference in percent cover of intermediate and perennial ryegrass transitioned to bermudagrass through the use of sulfonylurea herbicides. 


\section{Literature Cited}

Askew, S.D. 2007. Tackling the challenges of over-seeding and transitioning. Sports Turf Management. September.

Ayers, W.A. and R.H. Thornton. 1968. Plant Soil 28:193.

Barnes, J.P. and A.R. Putnam. 1987. Role of benzoxazalinones in allelopathy by rye (Secale cereal L.) J. Chem. Ecol. 13(4):889-906.

Barnes, J.P. and A.R. Putnam. 1986. Evidence for allelopathy by residues and aqueous extracts of rye (Secale cereale). Weed Sci. 34:384-390.

Barnes, J.P., A.R. Putnam, B.A. Burke, and A.J. Aasen. 1987. Isolation and characterization of allelochemicals in rye herbage. Phytochemistry 26 (5):1385-1390.

Beard, J.B. 2002. Turf Management for Golf Courses. Second Edition. Ann Arbor Press. Chelsea, Michigan.

Beehag, G.W. 2001. Sports Ground Overseeding. Golf \& Sports Turf - Australia. June.

Bevard, D.S. 2004. Breeding for the Future - High quality seeded bermudagrass is now a reality in the Transition Zone. United States Golf Association, Green Section Record May/June 2004.

Carrier, L. 1927. Florida Greenkeeping. National Greenkeeper, Oct. 1927. pp. 20 and 25.

Coder, K.D. 1999. Tree Allelochemicals: Ways and Means. Daniel B. Wornell School of Forest Resources. University of Georgia. April 1999.

DeCandolle, M.A.-P. 1832. "Physiologie Vegetale," Tome III, pp. 1474 to 1475. Bechet Jeune, Lib, Fac. Med., Paris.

Duble, R.L. 1996. Turfgrasses: Their Management and Use in the Southern Zone. Second Edition. Texas A\&M University Press. College Station, Texas.

Duble, R.L. 2004. Bermudagrass “The Sports Turf of the South”. Texas A\&M University Cooperative Extension.

Dunn, J.H., M.R. Warmund, E.H. Ervin, B.S. Fresenburg, and S.W. Dunn. 2000. University of Missouri Turfgrass Research Report.

Dunn, J.H., M.R. Warmund, E.H. Ervin, B.S. Fresenburg, and S.W. Dunn. 2001. University of Missouri Turfgrass Research Report. 
Dunn, J. and K. Diesburg. 2004. Turf management in the transition zone. John Wiley and Sons, Inc., Hoboken, New Jersey.

Enlow, C.R. and W.E. Stokes. 1929. Lawns in florida. Florida Agricultural Experiment Station Bulletin 209.

Fry, J., R. Taylor, B. Wolf, and A. Zuk. 2002. Evaluation of cultural methods for converting perennial ryegrass to seeded bermudagrass. 2002 Turfgrass Research Report. Kansas State University.

Gelernter, W. and L. Stowell. 2005. Improved over-seeding programs: 1. The role of weather. Golf Course Management. March 2005. pp. 108 to 113.

Gray, L.C. 1958. History of agriculture in the southern United States to 1860. Peter Smith, Gloucester, Mass. Reprinted as Publ. 430 by the Carnegie Institution of Washington.

Hanson, A. A. 1972. Breeding of grasses. pp. 36-52. In V. B. Youngner and C. M. McKeil (eds.) The Biology and utilization of grasses. Academic Press, New York.

Harborne, J.B. 1982. Introduction to ecological biochemistry. $2^{\text {nd }}$ ed. Academic, New York. $278 \mathrm{pp}$.

Harlan, J.R., J.M.J deWet, W.W. Huffine, and J.R. Deakin. 1970. A guide to the species of cynodon (Gramineae). Oklahoma State University Bulletin B-673.

Horgan, B. and F. Yelverton. 1998. How to kill perennial ryegrass in over-seeded fairways. Golf Course Management. August.

Horgan, B.P. and F.H. Yelverton. 2001. Removal of perennial ryegrass from over-seeded bermudagrass using cultural methods. Crop Sci. 41:118-126.

Huebner, P. 2003. Perennial \& annual ryegrass. Manitoba Agriculture. http://www.forageseed.mb.ca/RyegrassInfo.html.

King, J. 1996. Allelopathy vs. Acremonium endophytes vs. competition effects on crabgrass suppression by 12 perennial ryegrasses. 1996 University of Arkansas Research Report. University of Arkansas.

Kohli, R.K. Allelopathy and its implications in agro-ecosystems. "Crop Sciences and Recent Advances” editor, A.S. Basra. Haworth Press Inc. 1998.

Kopec, D.M., J. Gilbert, K. Marcum, M. Pessarakli, and D. Jensen. Effect of overseeding rate on spring transition. United States Golf Association Greens Section. July/August 2001. 
Laycock, R.W. and P.M. Canaway. 1980. A new optical point quadrant frame for the estimation of cover in close mowed turf. pp. 91-92. Journal of the Sports Turf Institute, Sports Turf Research Institute.

Mazur, A.R. Overseeding in transition. Golf Course Management. September 1993.pp 20.

Mazur, A.R. and J.S. Rice. 1999. Impact of over-seeding bermudagrass with various amount of perennial ryegrass for winter putting turf. HortScience, Vol. 34(5).

McCarty, L.B. 2001. Best Golf Course Management Practices. Prentice Hall. Upper Saddle River, New Jersey.

McCarty, L. B. and G. Miller. 2002. Managing bermudagrass turf-Selection, construction, cultural practices and pest management strategies. Ann Arbor Press, Michigan.

McCollum, S. 2002. Allelopathy: A Review. Thesis Introduction. Colorado State University. April 12, 2002.

McElroy, S. 2006. Overseeding bermudagrass: chemical vs natural transition. Sports Turf. February 2006. pp. 8.

Morris, K. National Bermudagrass Test. 1992. USDA-NTEP 97-9, pp. 84.

Morris, K. National Bermudagrass Test. 1997. USDA-NTEP 02-7, pp. 143.

Morris, K.N. Grasses for over-seeding bermudagrass fairways. Golf Course Management. Research Section. July 2004. pp. 89.

Patton, A.J., D.W. Williams, and Z.J. Reicher. Establishing seeded bermudagrass. Golf Course Management. Research Section. December 2004.

Puhala, J., J. Kranz, and M. Goatley. 1999. Sports Fields: A Manual for Construction and Maintenance. Ann Arbor Press. Chelsea, Michigan.

Putnam, A.R. and C.S. Tang. 1986. The Science of Allelopathy. John Wiley and Sons, Inc. New York, New York.

Putnam, A.R. and J. DeFrank. 1983. Use of phytotoxic plant residues for selective weed control. Crop Prot. 2:173-181.

Ray, T.B. 1982. Site of action of chlorsulfuron: A new herbicide for cereals. Pesticide Biochemistry and Physiology 17:10-17.

Rice, E. L. 1984. Allelopathy. Academic Press, $2^{\text {nd }}$ edition. April. 
Rivenshield, Angie. 2006. Allelopathy. CEIRP Fellowship Project. Cornell Science Inquiry Partnership. http://csip.cornell.edu/Projects/CEIRP/AR/Allelopathy.htm.

Schreiner, O., and Reed, H.S. (1907a). Certain organic constituents of soil in relation to soil fertility. U.S. Dept. of Agric., Bur. Soils Bull. No. 47.

Schreiner, O., and Reed, H.S. (1907b). The production of deleterious excretions by roots. Bull. Torrey Bot. Club 34, pp.279-303.

Shilling, D.G., R.A. Liebl, and A.D. Worsham. 1985. Rye and wheat mulch: The suppression of certain broadleaf weeds and the isolation and identification of phytotoxins. P.243-271. In A.C. Thompson (ed.) The chemistry of allelopathy: Biochemistry interactions among plants. Am. Chem. Soc., Washington, DC.

Skogley, C.R., and C.D. Sawyer. 1992. Field Research. pp.589-614. In A. Waddington (ed.) Turfgrass. Agron. Monogr. 32. ASA and SSSA, Madison, Wisconsin.

Taiz, L. and E. Zeiger. 2006. Plant Physiology. Fourth edition. Sinauer Associates, Inc. Sunderland, Massachusetts.

Thorogood, D. 2003. Perennial Ryegrass. In: Casler, M.D., Duncan, R.R. (eds) Turfgrass Biology, Genetics and Breeding Chapter, p. 75-105. John Wiley and Sons, Inc. Hoboken, New Jersey.

Turgeon, A.J. 2002. Turfgrass Management. Sixth Edition. Prentice Hall. Upper Saddle River, New Jersey.

Umeda, K. and G. Towers. Comparison of sulfonylurea herbicides for spring transition. University of Arizona Cooperative Extension. October 2004.

USGA Report. Turfgrass and Environmental Research. Vol. 3, Number 1, January 1, 2004.

Yelverton, F. In Transition. Grounds Maintenance. February 2004.

Yelverton, F. Spring transition: Going, going, gone. United States Golf Association. Greens Section Record. March/April 2005.

Zuk, A., and J. Fry. Factors affecting establishment of seeded zoysiagrass in perennial ryegrass turf. 2001 Turfgrass Research Report. Kansas State University. 


\section{Chapter 2}

\section{Allelopathic Activity of Intermediate and Perennial Ryegrasses on Bermudagrass ${ }^{1}$ Brad S. Fresenburg, Reid J. Smeda, Robert J. Kremer, and Chung-Ho Lin ${ }^{2}$}

Abstract: Allelopathy is a complex phenomenon used by plants to release beneficial or detrimental chemicals into the adjacent micro-environment. Perennial ryegrass in often over-seeded into bermudagrass, and there are suspicions that continual use of this practice may thin bermudagrass via the release of allelochemicals. Research was designed to identify the in vitro allelopathic activity of intermediate and perennial ryegrasses on bermudagrass. Plant extracts from shoots and roots of intermediate and perennial ryegrass cultivars reduced bermudagrass seed germination $62 \%$ within 10 days. However, no differences were observed between shoot and root extracts for each ryegrass cultivar, even though phenolic concentrations in shoot extracts $\left(0.179 \mathrm{mg}\right.$ of phenolics $\mathrm{g}^{-}$

$\left.{ }^{1}\right)$ of each ryegrass cultivar was higher than root extracts $\left(0.118 \mathrm{mg}\right.$ phenolics $\left.\mathrm{g}^{-1}\right)$. HPLC-MS/MS revealed eight fractions from perennial ryegrass roots which inhibited bermudagrass seed germination, four fractions that exhibited anti-fungal properties, and two fractions that displayed both germination inhibition and anti-fungal properties. Intermediate ryegrass extracts had fewer fractions that displayed bioactivity (one for germination, two for anti-fungal, and one for both). In vitro and HPLC fraction bioassays did indicate allelopathic activity on bermudagrass seed germination, fungal growth, or both.

${ }^{1}$ Received for publication and in revised form 
${ }^{2}$ Extension/Research Associate, Associate Professor, Division of Plant Sciences, University of Missouri, Columbia, MO 65211; Microbiologist, USDA-ARS, University of Missouri, Columbia, MO 65211; Associate Research Professor, University of Missouri, Columbia, MO 65211. Email address: fresenburgb@missouri.edu Nomenclature: Bermudagrass (Cynodon dactylon L. Pers.) ‘Riviera', ‘Savannah'; perennial ryegrass (Lolium perenne L.) 'Brightstar II', 'Evening Shade'; intermediate ryegrass (Lolium multiforum Lam. x Lolium perenne L.) 'Transeze’.

Additional Index Words: Allelochemicals, bioassay, ferulic acid, phenolic, root exudates.

Abbreviations: ACN, acetonitrile; HPLC, high-performance liquid chromatography; $\mathrm{Na}_{2} \mathrm{CO}_{3}$, sodium carbonate; GC-MS/MS, gas chromatography tandem mass spectrometry; HPLC-MS/MS, high-performance liquid chromatography tandem mass spectrometry; NIST/EPA/NIH, National Institute for Standard and Technology. 


\section{Introduction}

Allelopathy is a complex phenomenon involving numerous chemical interrelationships among plants (Kohli, 1998). McCollum (2002) defined allelopathy as the study of harmful and beneficial effects of one plant on another, utilizing allelopathic chemicals. In a competitive sense, the expression of allelopathy by plants is designed to prevent adjacent plants from optimal use of available resources, thus exerting competition. Allelopathic plants control the micro-environments in which they live. Allelochemicals can be released into the environment by a number of processes such as: leaching from above ground plant parts, root exudation, volatilization, decomposition of plant residue, and the incorporation of plant residues (living and dead) into the soil (Putnam and Tang, 1986).

Rye (Secale cereal L.) produces dense canopies that compete with weeds for light, water, and nutrients (Rice, 1984). Additionally, rye residues lying on the soil surface will reduce weed seed germination by serving as mulch, lowering soil temperatures, and serving as a physical barrier (Barnes and Putnam, 1986; Rice, 1984). Rye residues left on the surface will also leach phytotoxins into the soil inhibiting weed germination and seedling growth (Barnes et al., 1987).

King (1996) investigated the effects of twelve perennial ryegrass (Lolium perenne L.) cultivars on crabgrass (Digitaria spp.) seed germination. While results were inconsistent, some cultivars provided a 50 to $60 \%$ reduction in crabgrass germination when dried, powdered ryegrass tissue (stem-leaf) was mixed with the soil.

Zuk and Fry (2006) found that soils amended with 12\% perennial ryegrass leaf tissue reduced zoysiagrass germination and root mass compared to the untreated control. Fry et 
al. (2002) reported that bermudagrass (Cynodon spp.) seed sown into a live sward of perennial ryegrass resulted in only $12 \%$ coverage by the end of the first season (October). However, removal of perennial ryegrass with glyphosate resulted in $100 \%$ bermudagrass coverage by October.

In addition to perennial ryegrass, other turfgrass species appear to release compounds from roots which exhibit herbicidal properties. Weston (2006) found several cultivars of fine leaf fescues (Festuca spp.) contained m-tyrosine, a germination inhibitor of crabgrass, dandelion (Taraxacum officinale), and other small seeded weeds. Findings such as these facilitate for the development of synthetic herbicides that mimic natural products. One example is the development of mesotrione from lemon bottlebrush (Callistemon citrinus). Tenacity ${ }^{\circledR}$ (mesotrione) is being marketed in the turfgrass industry as a pre- and post-emergence herbicide for control of crabgrass, dandelion, nimblewill (Muhlenbergia schreberi J.F. Gmel.), and other weed species (Syngenta, 2008).

Despite some apparent negative aspects associated with perennial ryegrass, turfgrass managers over-seed bermudagrass with perennial ryegrass for many reasons. The mixture of both species provides a consistent green turf surface that provides greater attraction for fall, winter and early spring sports (McElroy, 2006). Intermediate ryegrasses have been under evaluation for quality and transitional characteristics for several years and are now being used for over-seeding bermudagrass athletic fields. Yelverton (2005) stated that when bermudagrass initiates spring growth, perennial ryegrass growth is optimal. As a result, perennial ryegrass poses significant shade over the emerging bermudagrass. Kopec et al. (2001) indicated that bermudagrass over- 
seeded with high rates $\left(898 \mathrm{~kg} \mathrm{ha}^{-1}\right)$ of perennial ryegrass had the lowest bermudagrass cover compared to lower seeding rates $\left(505 \mathrm{~kg} \mathrm{ha}^{-1}\right)$. Bermudagrass thinning can be a culmination of several years of over-seeding perennial ryegrass and allowing stands to persist (Yelverton, 2005); however it may also be the result of allelopathy.

To preclude direct competition versus release of allelochemicals, a series of greenhouse and laboratory experiments were initiated in 2007 to evaluate the allelopathic activity of intermediate and perennial ryegrasses on bermudagrass.

\section{Materials and Methods}

\section{$\underline{\text { In vitro Assay }}$}

Seedlings of 'BrightStar II' perennial ryegrass, 'Evening Shade' perennial ryegrass, and 'Transeze' intermediate ryegrass maintained in polypropylene containers ( 52 by 26 by $5 \mathrm{~cm}$ trays $^{1}$ ) with medium grade vermiculite were sown in a greenhouse in April and

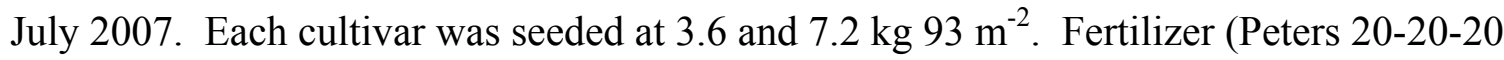
Multi-Purpose Soluble Fertilizer ${ }^{2}$ ) was applied at $0.84 \mathrm{~kg}$ nitrogen $\mathrm{ha}^{-1}$ at the time of grass seeding and two weeks after planting. Ryegrasses were maintained at a height of $3.8 \mathrm{~cm}$ for the duration ( 5 weeks) of growing plant material. At five weeks, above ground tissue in each flat was harvested by clipping stem and leaf tissue at the crown. Roots were thoroughly rinsed with water to remove all vermiculite.

Separate shoot and root tissue from each ryegrass cultivar were prepared for extraction of potential allelochemicals as follows: plant tissue was cut into small segments $(0.50$ $\mathrm{cm}$ ), placed into 250-ml flasks containing sterile, de-ionized water (10 g fresh material

\footnotetext{
${ }^{1}$ Product number F1020, Hummert International, 4500 Earth City Expressway, Earth City, Mo 63045

2 J.R. Peters, Inc., 6656 Grant Way, Allentown, PA 18106
} 
per $100 \mathrm{ml}$ water), and extracted by continuous agitation on a rotary shaker (200 rpm) for $24 \mathrm{~h}$ at room temperature (20 C) (Ben-Hammouda et al. 1995). Liquid extracts were filtered through Whatman ${ }^{3}$ No. 1 filter paper in a Buchner polypropylene vacuum funnel. Extracts were stored at $3^{\circ} \mathrm{C}$ prior to bioassays.

Sensitivity of bermudagrass to ryegrass extracts was assessed using an agar bioassay (Pedersen, 1986). Agar was added to water at $1 \% \mathrm{v} / \mathrm{v}$, then auto-claved for $20 \mathrm{~min}$ and placed in a water bath at $40^{\circ} \mathrm{C}$. Ryegrass extracts were allowed to equilibrate to room temperature and were passed through Fisherbrand ${ }^{4} 25 \mathrm{~mm}$ syringe filters $(0.45 \mu \mathrm{m}$ MCE sterile) to sterilize filtrates. Filtered extracts were added into a separate flask containing the agar solution at a ratio of 1:5 vol/vol plant extract:agar solution. Solutions were poured equally among three (replicates) sterile petri plates $(25 \mathrm{ml}$ per plate) mixed gently, then allowed to solidify at room temperature. Untreated controls received de-ionized water in place of ryegrass extracts.

Hulled 'Riviera' bermudagrass seed (testing 60\% germination) was soaked in $1.25 \%$ sodium hypochlorite for 4 minutes, and rinsed thoroughly with de-ionized water. After blotting dry, twenty seeds were equally spaced $(1 \mathrm{~cm})$ in a four by five grid pattern, centered on each petri plate. Petri plates were incubated at $27^{\circ} \mathrm{C}$ for the duration of the bioassay.

Germination of bermudagrass was recorded 5, 8, and 10 days after establishing seeds. Seed exhibiting a radical of $\geq 3 \mathrm{~mm}$ was considered germinated. The presence of fungal contamination was noted during the evaluation period.

\footnotetext{
${ }^{3}$ Whatman, Inc., Building 1, 800 Centennial Ave., Piscataway, NJ 08854

${ }^{4}$ Fisher Scientific, 2000 Park Lane Drive, Pittsburgh, PA 15275
} 
In vitro bermudagrass bioassays were conducted twice and combined. Proportional data were transformed using an arc sin square root transformation. Tables represent actual germination percentages, however all statistical inferences were performed on the transformed data. The AVOVA, in $\mathrm{SAS}^{5}$, was analyzed as a completely randomized design with four treatments ( 3 cultivars and untreated control) replicated three times. Mean differences were determined using Fisher's Least Significant Difference (LSD) at the 0.05 level of probability.

Total phenolic analysis of ryegrass extracts was conducted by the Folin-Denis method with ferulic acid as the standard (Ben-Hammouda et al. 1995). Extracts for both shoots and roots of each ryegrass species were prepared for spectrophotometric analysis by addition of $1 \mathrm{ml}$ of extract to $7.5 \mathrm{ml}$ de-ionized water, $0.5 \mathrm{ml}$ Folin-Denis reagent, and 1 $\mathrm{ml}$ saturated sodium carbonate $\left(\mathrm{Na}_{2} \mathrm{CO}_{3}\right)$ solution; samples were mixed thoroughly using a vortex mixer. After 30 minutes, absorbance was determined at $750 \mathrm{~nm}$. Total phenolic content was expressed as $\mathrm{mg}$ ferulic acid equivalent per gram of plant material. A standard curve was developed by reading absorbance for known concentrations of ferulic acid.

Phenolic concentration experiments were conducted twice and combined. The ANOVA was analyzed as a completely randomized design in which the treatments were arranged as a 2 by 2 factorial ( 2 levels of seeding rate and two levels of plant parts). Mean differences were determined using Fischer's Least Significant Difference (LSD) at the level of $\mathrm{p}=0.05$. All analyses were performed using PROC GLM in SAS (SAS, 2010).

${ }^{5}$ SAS Institute, 100 SAS Campus Drive, Cary, NC 27513 


\section{Fractionation of Allelopathic Compounds}

Seedlings of 'BrightStar II' perennial ryegrass and 'Transeze' intermediate ryegrass maintained in polypropylene containers ( 52 by 26 by $5 \mathrm{~cm}$ trays) with medium grade vermiculite were sown in a greenhouse in July 2009. Each cultivar was seeded at $7.2 \mathrm{~kg}$ $93 \mathrm{~m}^{-2}$. Fertilizer (Peters 20-20-20 Multi-Purpose Soluble Fertilizer) was applied at 0.84 $\mathrm{kg}$ nitrogen $\mathrm{ha}^{-1}$ at the time of grass seeding and two weeks later. Ryegrasses were maintained at a height of $3.8 \mathrm{~cm}$ for the duration ( 5 weeks) of growing plant material. At five weeks, above ground tissue in each flat was harvested by clipping stem and leaf tissue at the crown. Roots were thoroughly rinsed with water to remove all vermiculite.

Water extracts were prepared as described for the bermudagrass bioassay with the following modifications: twenty grams of roots for extraction were cut into small segments $(0.50 \mathrm{~cm})$, placed into $250-\mathrm{ml}$ flasks containing $100 \mathrm{ml}$ of sterile, de-ionized water, and extracted by continuous agitation on a rotary shaker $(200 \mathrm{rpm})$ for $24 \mathrm{~h}$ at room temperature (20 C) (Ben-Hammouda et al. 1995). Liquid extracts were filtered through Whatman No. 1 filter paper in a Buchner polypropylene vacuum funnel. Extracts were stored at $3^{\circ} \mathrm{C}$ prior to bioassays. Extracts were filtered through a Life Sciences ${ }^{6}$ Acrodisc CR 13 mm syringe filter (0.45 $\mu \mathrm{m}$ PTFE membrane HPLC Certified) prior to separation of compounds.

Separation and fractionation of the phytochemicals (root extracts of 'BrightStar II' perennial ryegrass and 'Transeze' intermediate ryegrass) were performed with a reverse phase chromatography column in a Shimadzu SCL-10Avp HPLC ${ }^{7}$ coupled with a

\footnotetext{
${ }^{6}$ Pall Life Sciences, 600 South Wagner Road, Ann Arbor, MI 48103

${ }^{7}$ Shimadzu Scientific Instruments, 7102 Riverwood Drive, Columbia, MD 21046
} 
Shimadzu FRC-1500 HPLC $^{8}$ micro fractionation system (Lin et al., 2007). Extracts (250 $\mu 1$ for each ryegrass species) were injected and separated into 30 fractions $(2.5 \mathrm{ml}$ per fraction extract) based upon wavelengths (200 and $240 \mathrm{~nm}$ ) and solvents. A solvent gradient was used during the fractionation process [35\% acetonitrile (ACN) and $65 \%$ water to $100 \% \mathrm{ACN}$ to $35 \% \mathrm{ACN}$ and $65 \%$ water] to release corresponding compounds affected by the solvent concentrations. A Phenomenex Columbus $5 \mu$ C8 110A $250 \mathrm{x}$ $4.60 \mathrm{~mm}$ column ${ }^{9}$ was used for the stationary phase. This process was repeated nine times for each ryegrass species to provide $22.5 \mathrm{ml}$ of combined fractionated extracts. Combined fractions were reduced from $22.5 \mathrm{ml}$ to $3 \mathrm{ml}$ using a nitrogen evaporator to concentrate fractionated compounds. Bioassays with bermudagrass seed were performed on each fraction to test effects on seed germination.

Fractionations for 'BrightStar II' perennial ryegrass and 'Transeze' intermediate ryegrass were prepared for bermudagrass seed bioassays (Bowers et al., 1997). Disposable petri dishes $(60 \mathrm{~mm} \times 15 \mathrm{~mm})$ with $5.5 \mathrm{~cm}$ Whatman No.2 filter paper placed in the dish received $0.2 \mathrm{ml}$ of fractioned extract placed in the center of the paper and allowed to dry (this allowed for volatilization of $\mathrm{ACN}$ ). Each dish was rejuvenated with $2 \mathrm{ml}$ de-ionized water and bermudagrass seed was prepared for planting. Untreated controls contained water only while untreated check plates contained ACN.

Hulled 'Savannah' bermudagrass seed (tested 37\% germination) was soaked in $1.25 \%$ sodium hypochlorite for 4 minutes, and rinsed thoroughly with de-ionized water. After blotting dry, twenty seeds were equally spaced $(1 \mathrm{~cm})$ in a four by five grid pattern,

\footnotetext{
${ }^{8}$ Shimadzu Scientific Instruments, 7102 Riverwood Drive, Columbia, MD 21046

${ }^{9}$ Phenomenex, 411 Madrid Ave., Torrance, CA 90501
} 
centered on filter paper in each petri plate. Petri dishes were maintained in darkness for the duration of the bioassay.

Germination counts were taken 5, 8, and 10 days after sowing seeds. Seed exhibiting a radical of $\geq 3 \mathrm{~mm}$ was considered germinated. The presence of fungal contamination was noted during the evaluation period. Active compounds indicated by bioactivity were selected for further analysis by chromatography/mass spectrometry.

Fractionation bermudagrass bioassays were conducted twice and combined. Proportional data were transformed using an arc sin square root transformation. Tables represent actual germination percentages, however all statistical inferences were performed on the transformed data. The AVOVA, in SAS, was a completely randomized design with three treatments ( 2 cultivars and untreated control) and replicated three times. Mean differences were determined using Fisher's Least Significant Difference (LSD) at the level of $p=0.05$.

\section{Results and Discussion}

\section{$\underline{\text { In Vitro Assay }}$}

In vitro assays for 'Brightstar II' perennial ryegrass reduced bermudagrass seed germination by 50,55 , and $59 \%$ for 5,8 , and 10 days after seeding (DAS), respectively, compared to the untreated control (Table 2-1). "Evening Shade' perennial ryegrass and 'Transeze' intermediate ryegrass had similar bioassay results reducing bermudagrass seed germination by 54,59 , and $62 \%$ for 5,8 , and 10 days after seeding (DAS), respectively (Table 2-1). These results confirm King's (1996) findings that some perennial ryegrass 
cultivars provided 50 to $60 \%$ reduction in crabgrass germination when dried, powdered ryegrass tissue (stem-leaf) was mixed with the soil.

Root exudates are commonly collected for assessment of allelopathic potential (Putnam and Tang, 1986). Rye residues from shoots remaining on the soil surface leach phytotoxins into the soil inhibiting weed germination and seedling growth (Barnes et al., 1987). While allelochemicals are being reported as shoot and root contributing, no differences were observed between shoot and root extracts of perennial and intermediate ryegrass (data not shown). One growth chamber study conducted by McCauley et al. (2009) also showed no differences among pots (seeded with bermudagrass) and treated

with irrigation water containing various concentrations $\left(0,5,10\right.$, or $\left.20 \mathrm{~g} \mathrm{~L}^{-1}\right)$ of perennial ryegrass shoot and root extracts. No differences were observed among seed rates (data not shown).

\section{$\underline{\text { Phenolic Content }}$}

Phenolic concentrations for each ryegrass cultivar were determined for shoots and roots of both seeding rates. Differences were only observed comparing shoots to roots for each cultivar (Table 2-2). While shoots contained an average of $0.179 \mathrm{mg}$ of phenolics $\mathrm{g}^{-1}$ plant tissue and roots contained an average of $0.118 \mathrm{mg}$ phenolics $\mathrm{g}^{-1}$ plant tissue over all ryegrass cultivars; no differences were observed during the in vitro bioassays between shoots and roots (data not shown). No differences were observed between seeding rates as well for all ryegrass cultivars (data not shown).

McCauley et al. (2009) in a second growth chamber study noted differences between inhibitory effects (bermudagrass germination, ash weight, root length, and root mass) of shoot and root tissue of perennial ryegrass. He stated that various blends of fresh 
ryegrass root tissue with the soil media $(0,2,12$, and $23 \%$ per $25 \mathrm{~g}$ soil) had minimal impact upon bermudagrass germination, while shoot tissue reduced bermudagrass germination, ash weight, root length density, and root mass density by 33 to $54 \%$. McCauley did not indicate or speculate any underlying allelochemicals. He suggested inhibition of bermudagrass growth and development by allelochemicals only resulted from severed and decaying ryegrass shoots.

\section{Fractionation Bioassays}

All root fractionations (30) for perennial and intermediate ryegrasses were tested for effects on bermudagrass germination and anti-fungal properties. Eight fractions of perennial ryegrass inhibited bermudagrass seed germination, four exhibited anti-fungal properties, and two displayed both germination inhibition and anti-fungal properties (Table 2-3). Intermediate ryegrass had far fewer fractions displaying any bioactivity (one for germination, two for anti-fungal, and 1 for both) (Table 2-3).

Over-seeding ryegrasses into bermudagrass offers several benefits to turfgrass managers. However, allowing stands of ryegrass to persist, results in thinning of the bermudagrass sward. In vitro bioassays and fractionated root extracts of both ryegrasses have shown a negative impact on bermudagrass seed germination. With the release of potential allelochemicals from shoots and roots of intermediate and perennial ryegrasses, recovery of bermudagrass during spring transition may be negatively impacted. 


\section{Literature Cited}

Barnes, J.P. and A.R. Putnam. 1987. Role of benzoxazalinones in allelopathy by rye (Secale cereal L.) J. Chem. Ecol. 13(4):889-906.

Barnes, J.P., A.R. Putnam, B.A. Burke, and A.J. Aasen. 1987. Isolation and characterization of allelochemicals in rye herbage. Phytochemistry 26 (5):1385-1390.

Ben-Hammouda, M., R.J. Kremer, H.C. Minor, and M. Sarwar. 1995. A chemical basis for differential allelopathic potential of sorghum hybrids on wheat. J. Chem. Ecol. 21:775-786.

Bowers, N., J.R. Pratt, D. Beeson, and M. Lewis. 1997. Comparative evaluation of soil toxicity using lettuce seeds and soil ciliates. Environmental Toxicology and Chemistry 16: 207-213.

Lin, C.H., R.N. Lirch, H.E. Garrett, Y.X. Li, and M.F. George. 2007. An improved HPLC-MS/MS method for determination of isoxaflutole (Balance ${ }^{\circledR}$ ) and its metabolites in soils and forage plants. Journal of Agricultural and Food Chemistry 55:3895-3815.

Fry, J., R. Taylor, B. Wolf, and A. Zuk. 2002. Evaluation of cultural methods for converting perennial ryegrass to seeded bermudagrass. 2002 Turfgrass Research Report. Kansas State University.

King, J. 1996. Allelopathy vs Acremonium endophytes vs competition effects on crabgrass suppression by 12 perennial ryegrasses. 1996 Arkansas Research Report. University of Arkansas.

Kohli, R.K. 1998. Allelopathy and its implications in agro-ecosystems. "Crop Sciences and Recent Advances" editor, A.S. Basra. Haworth Press Inc.

Kopec, D.M., J. Gilbert, K. Marcum, M. Pessarakli, and D. Jensen. 2001. Effect of overseeding rate on spring transition. United States Golf Association Greens Section. July/August.

McCauley, R., L.B. McCarty, H. Liu, and J. Toler. 2009. Allelopathic Properties of Overseeded Ryegrass on Bermudagrass Spring Greenup. Clemson University, Clemson, SC. WSSA Meeting Abstracts \#391.

McCollum, S. 2002. Allelopathy: A Review. Master's Thesis Introduction. Colorado State University. April 12, 2002.

McElroy, S. 2006. Overseeding bermudagrass: chemical vs natural transition. Sports Turf. February, pp. 8. 
Pederson, G. A. 1986. White clover seed germination in agar containing tall fescue extracts. Crop Sci. 26:1248-1249.

Putnam, A.R. and C.S. Tang. 1986. The Science of Allelopathy. John Wiley and Sons, Inc. New York, New York.

Rice, E. L. 1984. Allelopathy. Academic Press, $2^{\text {nd }}$ edition. April.

SAS. 2010. Version 9.2. SAS Institute Inc. 100 ASA Campus Drive, Cary, NC 275132414 USA.

Syngenta Technical Bulletin - Tenacity. 2008. Syngenta Professional Products, PO Box 16300, Greensboro, NC 27419.

Weston, L. A. 2006. Development of allelopathic turfgrass cultivars for enhanced weed suppression in roadside and landscape settings. From CALS annual faculty reporting. Imported on June, 21, 2007. Cornell University.

Yelverton, F. 2005. Spring transition: Going, going, gone. United States Golf Association. Greens Section Record. March/April.

Zuk, A.J. and J. D. Fry. 2006. Inhibition of 'Zenith' zoysiagrass seedling emergence and growth by perennial ryegrass leaves and roots. Hort. Sci. 41: p. 818-821 (June). 
Table 2-1. Bermudagrass germination ${ }^{\mathrm{a}}$ from in vitro bioassays using ryegrass extracts from 'Brightstar II', 'Evening Shade', and 'Transeze' ryegrass cultivars. Results were combined over two trials (May, August, 2007).

\begin{tabular}{lccc}
\hline Cultivar & $5 \mathrm{DAS}^{\mathrm{b}}$ & \% Germination & \\
\hline Untreated Control & $22 \mathrm{a}$ & $8 \mathrm{DAS}$ & $10 \mathrm{DAS}$ \\
BrightStar II & $11 \mathrm{~b}$ & $27 \mathrm{a}$ & $32 \mathrm{a}$ \\
Evening Shade & $10 \mathrm{~b}$ & $12 \mathrm{~b}$ & $13 \mathrm{~b}$ \\
Transeze & $10 \mathrm{~b}$ & $11 \mathrm{~b}$ & $12 \mathrm{~b}$ \\
\hline LSD $(0.05)$ & 7.4 & $11 \mathrm{~b}$ & $12 \mathrm{~b}$ \\
\hline
\end{tabular}

${ }^{a}$ Germination: Percent actual germination - Based on $60 \%$ germination rate, 20 seeds per plate, 3 replications.

${ }^{\mathrm{b}}$ Abbreviation: Germination 5, 8, or 10 Days After Sowing. 
Table 2-2. Phenolic concentrations ${ }^{\mathrm{a}}$ in shoot and root extracts from 'Brightstar II', 'Evening Shade', and 'Transeze' ryegrass cultivars. Results were combined over two trials (May, August, 2007).

\begin{tabular}{llll}
\hline Plant Extract & Brightstar II & Evening Shade & Transeze \\
\hline Shoots & $0.170 \mathrm{a}$ & $0.177 \mathrm{a}$ & $0.189 \mathrm{a}$ \\
Roots & $0.118 \mathrm{~b}$ & $0.117 \quad \mathrm{~b}$ & $0.118 \mathrm{~b}$ \\
\hline LSD $(0.05)$ & 0.012 & 0.016 & 0.015 \\
\hline
\end{tabular}

${ }^{a}$ Phenolic concentration: mg ferulic acid equivalent $\mathrm{g}^{-1}$ plant material (Ben-Hammouda et al. 1995). 
Table 2-3. HPLC fractions of perennial and intermediate ryegrass root extracts showing bioassay activity on bermudagrass seed germination, fungal growth or both. Results were combined over two trials (August, 2009).

\begin{tabular}{|c|c|c|c|c|c|}
\hline \multicolumn{2}{|c|}{ Brightstar II perennial ryegrass } & \multicolumn{3}{c|}{ Transeze intermediate ryegrass } \\
\hline Germination & \multicolumn{2}{|c|}{ Fungal } & Both & \multicolumn{4}{c|}{ Germination } & Fungal & Both \\
\hline \multicolumn{3}{|c|}{ Fraction Number } & \multicolumn{3}{c|}{ Fraction Number } \\
\hline 2 & 14 & 11 & 9 & 1 & 7 \\
\hline 8 & 15 & 12 & - & 27 & - \\
\hline 10 & 27 & - & - & - & - \\
\hline 11 & 30 & - & - & - & - \\
\hline 14 & - & - & - & - & - \\
\hline 20 & - & - & - & - & - \\
\hline 24 & - & - & - & - & - \\
\hline 29 & - & - & - & - & - \\
\hline
\end{tabular}




\section{Chapter 3}

\section{Spring Removal of Intermediate and Perennial Ryegrass (Lolium spp.) from Bermudagrass (Cynodon dactylon L. Pers.) by Cultural Practices ${ }^{1}$}

\section{Brad S. Fresenburg and Reid J. Smeda ${ }^{2}$}

Abstract: The practice of over-seeding perennial ryegrass onto bermudagrass results in green turf on golf courses and athletic fields during periods when most turf areas are discolored or dormant. In spring, ryegrass is often removed by cultural practices to preserve the health of the underlying bermudagrass. Bermudagrass recovery requires a 100 day period beyond the complete removal of ryegrass, which becomes a concern of turf managers in the Transition Zone. Objectives of this research were to manipulate mowing height and nitrogen fertility to remove perennial ('Brightstar II') and intermediate ('Transeze') ryegrass from bermudagrass, thereby providing opportunity for complete bermudagrass recovery. Reducing mowing height of perennial ryegrass from 5 to $2.5 \mathrm{~cm}$ had no impact on density. Decreasing mowing height reduced intermediate ryegrass density $10 \%$ by 1 and 3 weeks after treatment (WAT), but plants recovered by 5 WAT. Sequential applications of nitrogen fertilizer increased ryegrass density 4 and $11 \%$ for perennial and intermediate ryegrass, respectively by $1 \mathrm{WAT}$, followed by a gradual decrease. Reduction in ryegrass density concomitantly led to increased density of bermudagrass. Open space, where ryegrass was eliminated but bermudagrass had not yet greened up, decreased to 0 for perennial ryegrass by 5 WAT for each mowing height, independent of fertilizer use. For intermediate ryegrass, open space (up to $7 \%$ by 3 WAT; $1 \%$ by 5 WAT) was prolonged due to the ease of transition and cooler weather conditions for each mowing height, independent of fertilizer use. Bermudagrass quality 
increased up to $25 \%$ from the time nitrogen was applied through 5 WAT compared to plant quality in the absence of nitrogen. Increased mowing height of bermudagrass had less impact on quality (up to $6 \%$ ) compared to nitrogen applications. Results indicate that cultural practices alone were in-effective in removal of perennial ryegrass from bermudagrass, as densities remained above $20 \%$ by 5 WAT. However, the transition of intermediate ryegrass to bermudagrass was nearly complete (up to $90 \%$ bermudagrass cover) by 5 WAT with decreasing mowing height, independent of fertilizer.

${ }^{1}$ Received for publication and in revised form

${ }^{2}$ Extension/Research Associate, Associate Professor, Division of Plant Sciences, University of Missouri, Columbia, MO 65211, University of Missouri, Columbia, MO 65211. Email address: fresenburgb@missouri.edu Nomenclature: Bermudagrass (Cynodon dactylon L. Pers.) 'Riviera', perennial ryegrass (Lolium perenne L.) 'Brightstar II', intermediate ryegrass (Lolium multiforum Lam. x Lolium perenne L.) 'Transeze'.

Additional Index Words: Spring transition, over-seeding, winter dormancy. Abbreviations: WAT, weeks after treatment; ALS, acetolactate synthase. 


\section{Introduction}

Over-seeding bermudagrass (Cynodon spp.) with perennial ryegrass (Lolium perenne) is a common cultural practice in southern golf courses and athletic fields. Over-seeding is performed in late summer through early fall as bermudagrass becomes dormant, following exposure to extended periods below 10 C (50 F) (McCarty and Miller, 2002). Aesthetically, consistent green color is desirable for golf courses and athletic fields containing bermudagrass. In addition, golf course fairways are also over-seeded to clearly mark suggested landing areas for golfers. Over-seeding improves winter and spring playing conditions compared to golfing on dormant bermudagrass (McCarty and Miller, 2002). Over-seeding is an important economic aspect of southern golf resorts, because their heaviest usage by tourists occurs during the fall, winter, and spring months.

The practice of over-seeding perennial ryegrass creates competition for bermudagrass. In spring, removal of ryegrass is aimed at preserving the health of underlying bermudagrass (Askew, 2007). Yelverton (2004) stated that a timely transition is key to ensuring the health of bermudagrass, and failure to adequately remove perennial ryegrass will ultimately result in a decline in the bermudagrass stand. Therefore, the objective of spring transition is complete removal of perennial ryegrass and full recovery of bermudagrass. Full recovery of bermudagrass includes not only 100 percent ground cover, but also sufficient rhizome and stolon growth to provide surface strength (Yelverton, 2004).

Breeding cold tolerant cultivars of bermudagrass has enabled the practice of overseeding into the northern region of the Transition Zone in the United States. There, groundskeepers are more concerned about the lack of bermudagrass density in spring due 
to a shorter growing season, limiting recovery. Warm growing seasons of 100 days or more are needed for recovery of the bermudagrass sward (Yelverton, 2004 and 2005).

As spring approaches, several cultural practices are often implemented to remove ryegrasses. McCarty (2001) and Beard (2002) suggested the proper timing of increased fertility levels, lower mowing heights, mechanical groomers and slicers, and topdressing sand. Beard (2002) suggested the key biological indicator for spring transition is a soil temperature of $17 \mathrm{C}(62 \mathrm{~F})$ at a $10 \mathrm{~cm}(4 \mathrm{inch})$ depth for bermudagrass growth.

Horgan and Yelverton (1998) outlined cultural methods for removing ryegrass because these practices seem to be the most popular techniques for golf course superintendents. Methods included: lower mowing heights to allow better light penetration of the turf canopy; vertical slicing and core cultivation to warm the soil and stimulate bermudagrass growth; and the use of high ammonium nitrate rates $\left(49 \mathrm{~kg} \mathrm{~N}\right.$ ha $^{-}$ $\left.{ }^{1}\right)$ to desiccate the ryegrass tissue. Horgan and Yelverton (1998) suggested that combinations of these practices promoted optimum ryegrass removal.

Much of the research on cultural techniques for ryegrass removal has been conducted in southern climates, with little information from northern regions of the Transition Zone. Objectives of this research were to determine if spring removal of intermediate and perennial ryegrasses from bermudagrass could be completed through the use of close mowing and applications of nitrogen fertilizer providing opportunity for complete bermudagrass recovery. 


\section{Materials and Methods}

'Riviera' bermudagrass was established at the University of Missouri Turfgrass Research facility near Columbia, MO. On September 28, 2005, September 23, 2006, and September 15, 2007, 'Brightstar II' perennial ryegrass and 'Transeze' intermediate ryegrass were surface seeded in 19.5 by $22 \mathrm{~m}$ areas with a 1.1-m width Gandy drop

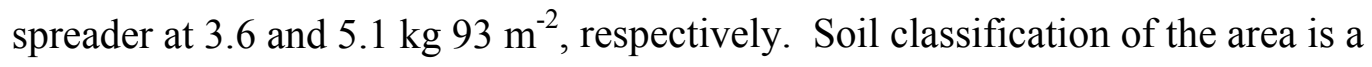
'Mexico' silt loam (fine, smectitie, mesic, Aeric Vertic Epiaqualfs) with $\mathrm{pH}$ of 5.8 and organic matter of $3.1 \%$. Overseeded blocks were irrigated as needed to ensure germination and establishment of ryegrasses.

Mowing and fertilizer treatments were initiated the following spring (May 26, 2006, May 21, 2007, and May 16, 2008). The experimental design was a strip-split plot with mowing heights $(2.5 \mathrm{~cm}, 3.8 \mathrm{~cm}$, and $5 \mathrm{~cm})$ randomly stripped in four replications by fertilizer applications (49 $\mathrm{kg}$ urea nitrogen $\mathrm{ha}^{-1}$ at 0 and 2 weeks after treatment (WAT)) stripped randomly and perpendicular to mowing treatments. Mowing heights were maintained twice per week during the duration of the trial with a reel-type tri-plex mower (2.5 $\mathrm{cm}$ mowing height) and zero-turn rotary mower ( 3.8 and $5.0 \mathrm{~cm}$ mowing heights).

Ryegrass transition was evaluated by taking specie counts using a modified pointquadrant system at $0,1,3$, and $5 \mathrm{WAT}$, and converting to a scale of 0 to $100 \%$ (Laycock and Canaway, 1980). Ten fixed points were randomly recorded five times per plot, for a total of 50 counts per evaluation date. This method determined what was present in the sample area (bermudagrass, ryegrass or open space). Transitional quality was estimated at $0,1,3$, and 5 WAT on a scale of 1 to 9 , with 9 indicating the highest quality (Skogley and Sawyer, 1992). Quality ratings of 6 or greater are considered acceptable (Skogley 
and Sawyer, 1992). Quality was based on canopy uniformity including color and density of bermudagrass as well as density of perennial or intermediate ryegrass.

Data were analyzed as a reported measure design in which the main plot contains the effect of cultivar, mowing, and fertilizer with all possible interactions of cultivar, mowing and fertilizer. Lacking a significant interaction of time with treatment variable, results were pooled prior to analysis. The subplot contained the effect of which and all possible interactions with the main plot effect. Mean differences were determined using Fisher's Least Significant Difference (LSD) at the 0.05 level of probability.

\section{Results and Discussion}

Prior to initiating treatments, ryegrass density ranged from 50 to $68 \%$ (Figures $3-1$ and 3-2). Bermudagrass density comprised 24 to $45 \%$ (Figures 3-3 and 3-4), with the remaining 3 to $6 \%$ of space lacking vegetation (Figures 3-5 and 3-6). Evaluations recorded changes in amounts of ryegrass and bermudagrass from these base numbers throughout the spring transition upon initiation of cultural practices.

\section{'Brightstar II' Perennial Ryegrass}

Perennial ryegrass density in bermudagrass decreased over the 5 week duration of this research. Lowering mowing height from 5 to $2.5 \mathrm{~cm}$ had little impact on perennial ryegrass removal (Figure 3-1). It was also noted that nitrogen level $\left(0\right.$ or $\left.49 \mathrm{~kg} \mathrm{ha}^{-1}\right)$ did not influence ryegrass removal rates. In fact, the addition of nitrogen increased ryegrass density 39 to $43 \% 1 \mathrm{WAT}$, indicating ryegrass growth was stimulated by fertilizer applications. Increasing ryegrass density may increase competitiveness against bermudagrass, resulting in reduced bermudagrass cover (Yelverton, 2005). Newer 
cultivars of perennial ryegrass like 'Brightstar II' have increased heat and drought tolerance. These new cultivars provide excellent fall and winter cover, but may lead to problems such as "clumpy" ryegrass if complete removal from bermudagrass is not achieved (Mazur and Wagner, 1987). The presence of 22 to $32 \%$ perennial ryegrass remaining after 5 weeks would likely result in persistent clumpy ryegrass.

Although initial bermudagrass density varied between 24 and $41 \%$, density at 5 WAT exceeded $70 \%$ for all treatments except the $5 \mathrm{~cm}$ mowing height with nitrogen (Figure 33), indicating that removal of ryegrass competition did not enhance bermudagrass recovery. It was noted that the use of nitrogen did not increase bermudagrass cover for each mowing height at 3 and 5 WAT (Figure 3-3). The use of nitrogen slowed the progression of bermudagrass, likely because ryegrass more efficiently used the nitrogen.

Open space during the transition from ryegrass to bermudagrass decreased more rapidly with nitrogen applications (Figure 3-5). At each mowing height, open space was at least $50 \%$ lower with nitrogen applications, and at the 2.5 and $5 \mathrm{~cm}$ mowing heights, the elimination of open space occurred 2 weeks earlier. Minimal open space does provide for a smooth (lack of open space) transition even if the remaining turfgrass species include both ryegrass and bermudagrass.

Transitional quality is a term that takes into consideration how smooth the transition was made from ryegrass to bermudagrass. Transitional quality also considers how well bermudagrass recovers without the existence of ryegrass. Quality ratings of 6 or greater are considered acceptable (Skogley and Sawyer, 1992). Transitional quality increased up to $25 \%$ over time ( 0 to $5 \mathrm{WAT}$ ) where nitrogen was applied (Figure $3-7$ ). Quality also increased up to $5 \%$ as mowing height increased from 2.5 to $5 \mathrm{~cm}$ since turfgrass canopy 
appeared more uniform. Higher quality $(>7.0)$ can also be attributed to lower open space ( $1 \%$ or less; 5 WAT) (Figures 3-5 and 3-7) and where bermudagrass plus ryegrass provided $100 \%$ cover (Figures 3-1 and 3-3).

\section{‘Transeze' Intermediate Ryegrass}

Although initial densities for intermediate versus perennial ryegrass were similar, the rate of density reductions for intermediate ryegrass was greater following the initiation of treatments (Figure 3-1 versus 3-2). Lowering mowing height from 5 to $2.5 \mathrm{~cm}$ decreased intermediate ryegrass density by $10 \%$ for the 1 and 3 WAT evaluations, but differences were minimal at 5 WAT (Figure 3-2). Similar to perennial ryegrass, nitrogen applications increased intermediate ryegrass density from 22 to $33 \%$ by 1 WAT (Figure $3-2$ ). Intermediate ryegrass densities decreased by $44 \%$ over time from 0 to 5 WAT. It is likely that genotypic characteristics contributed to transitioning of intermediate ryegrass, because mowing alone had minimal impact.

Initial bermudagrass density ranged from 30 to $45 \%$ and exceeded $80 \%$ by 5 WAT for all treatment combinations (Figure 3-4). Increases in bermudagrass density were noted more quickly after nitrogen applications; final bermudagrass density was similar among mowing heights regardless of nitrogen treatments.

Open space was most impacted by the addition of nitrogen. At each mowing height, all open space was eliminated at least two weeks sooner when nitrogen was applied (Figure 3-6). Open space did not appear to respond to mowing height alone, although the combination of mowing plus nitrogen resulted in the greatest rate of reduction from 3 to 5 WAT. Open space was reduced from a high of $7 \%$ at 3 WAT to 0 at 5 WAT. Open 
space less than $10 \%$ is not usually a concern for turf managers when provided a 100 day window for bermudagrass recovery (Yelverton, 2004).

Transitional quality increased up to $23 \%$ over time ( 0 to 5 WAT) when nitrogen was applied (Figure 3-8). Quality also increased up to $4 \%$ as mowing height increased from 2.5 to $5 \mathrm{~cm}$ improving turfgrass uniformity. Lower transitional quality (between 6 and 7) can be attributed to the slightly higher open space (by $4 \%$ ) compared to perennial ryegrass (Figures 3-8 versus 3-7).

Independent of mowing height, the use of nitrogen on perennial ryegrass and bermudagrass ensured an acceptable level of quality ( $>6)$, and elimination of open space by 3 to 5 weeks after initiating treatments. However, the perennial ryegrass did not transition below $20 \%$, potentially developing into clumpy ryegrass; concomitantly, the level of bermudagrass did not exceed $80 \%$, indicating an undesirable level of ryegrass competition with bermudagrass. The use of close mowing with or without nitrogen reduced overall levels of intermediate ryegrass to approximately $10 \%$. With this same treatment combination, bermudagrass density reached 85 to $90 \%$; elimination of open space was not complete until 5 weeks after initiating treatments. Overall transitional quality with close mowing was unacceptable in the absence of nitrogen, but approached 7 with nitrogen applications.

Weather, especially in the Transition Zone, is an important factor in how turfgrass managers will successfully remove ryegrass from bermudagrass. Spring air temperature fluctuations were observed in all three years. Average maximum air temperatures for late May during 2006 and 2008 dropped to nearly $15^{\circ} \mathrm{C}$ while in early June of 2007 and 2008 , they dropped to nearly $20^{\circ} \mathrm{C}$ (Figure 3-9). Cooler air temperatures slow 
bermudagrass recovery and have a negative effect on ryegrass removal. Cooler spring temperatures over all three years may have allowed perennial ryegrass to remain longer (>20\% at 5 WAT) (Figure 3-1). Ryegrass survives later into spring and beyond due to cool, wet conditions (Horgan and Yelverton, 2001). As a result, removal of perennial ryegrass, by cultural practices, can be very limiting in the Transition Zone. Introduction of intermediate ryegrasses can improve spring removal of ryegrass from bermudagrass as intermediate cultivars more quickly transitioned when temperatures exceed $29 \mathrm{C}$ (Beard, 2002).

Results indicate that cultural practices alone were not effective in removal of perennial ryegrass from bermudagrass, as densities remained above $20 \%$ by 5 WAT. However, the transition of intermediate ryegrass to bermudagrass was nearly complete (up to $90 \%$ bermudagrass cover) by 5 WAT with decreasing mowing height, independent of fertilizer. Turfgrass managers planning to use cultural practices for the removal of ryegrass from bermudagrass may need to consider additional use of herbicides for complete removal of ryegrass. 


\section{Literature Cited}

Askew, S.D. 2007. Tackling the challenges of over-seeding and transitioning. Sports Turf Management. September.

Beard, J.B. 2002. Turf Management for Golf Courses. Second Edition. Ann Arbor Press. Chelsea, Michigan.

Bruneau, A.H., J.M. Dipaola, W.M. Lewis, W.B. Gilbert, and L.T. Lucas. 1985. Overseeding bermudagrass turf. N.C. Agric. Ext. Serv. AG-352.

Horgan, B. and F. Yelverton. 1998. How to kill perennial ryegrass in over-seeded fairways. Golf Course Management. August.

Horgan, B.P. and F.H. Yelverton. 2001. Removal of perennial ryegrass from overseeded bermudagrass using cultural methods. Crop Sci. 41:118-126.

Laycock, R.W. and P.M. Canaway. 1980. A new optical point quadrant frame for the estimation of cover in close mowed turf. pp. 91-92. Journal of the Sports Turf Institute, Sports Turf Research Institute.

Mazur, A.R., and D.F. Wagner. 1987. Influence of aeration, topdressing, and vertical mowing on overseeded bermudagrass putting green turf. Hort. Sci. 22: No. 6, p. 12761278. December.

McCarty, L.B. 2001. Best Golf Course Management Practices. Prentice Hall. Upper Saddle River, New Jersey.

McCarty, L. B. and G. Miller. 2002. Managing bermudagrass turf - Selection, construction, cultural practices and pest management strategies. Ann Arbor Press, Michigan.

Meyers, H.G., and G.C. Horn. 1970. Transition from over-seeded to permanent warmseason grasses. Golf Superintendent 38(1):62-65.

Skogley, C.R., and C.D. Sawyer. 1992. Field Research. pp.589-614. In A. Waddington (ed.) Turfgrass. Agron. Monogr. 32. ASA and SSSA, Madison, Wisconsin.

Thorogood, D. 2003. Perennial Ryegrass. In: Casler, M.D., Duncan, R.R. (eds) Turfgrass Biology, Genetics and Breeding Chapter, p. 75-105. John Wiley and Sons, Inc. Hoboken, New Jersey.

Umeda, K. and G. Towers. 2004. Comparison of sulfonylurea herbicides for spring transition. University of Arizona Cooperative Extension. October. 
Yelverton, F. 2004. In Transition. Grounds Maintenance. February.

Yelverton, F. 2005. Spring transition: Going, going, gone. United States Golf Association. Greens Section Record. March/April. 


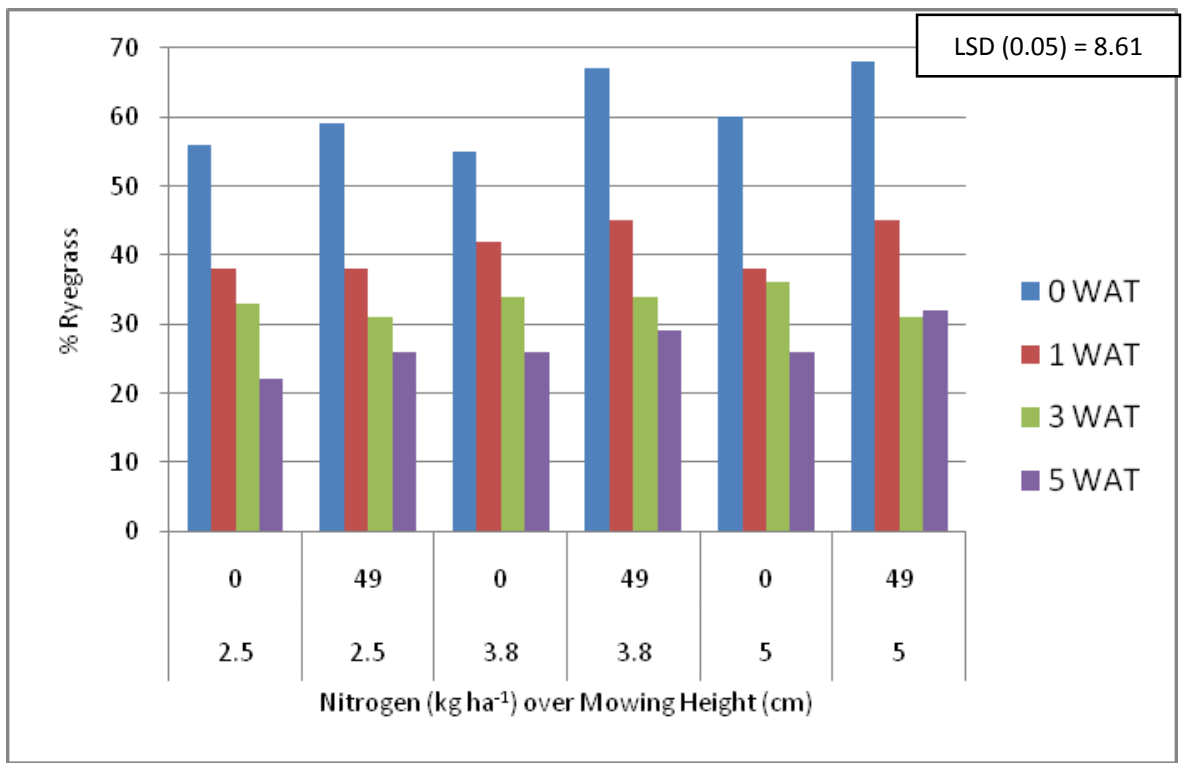

Figure 3-1. Removal of 'Brightstar II' perennial ryegrass from bermudagrass by mowing and application of urea fertilizer. Results were combined over three years (Columbia, MO - 2006, 2007, 2008). 


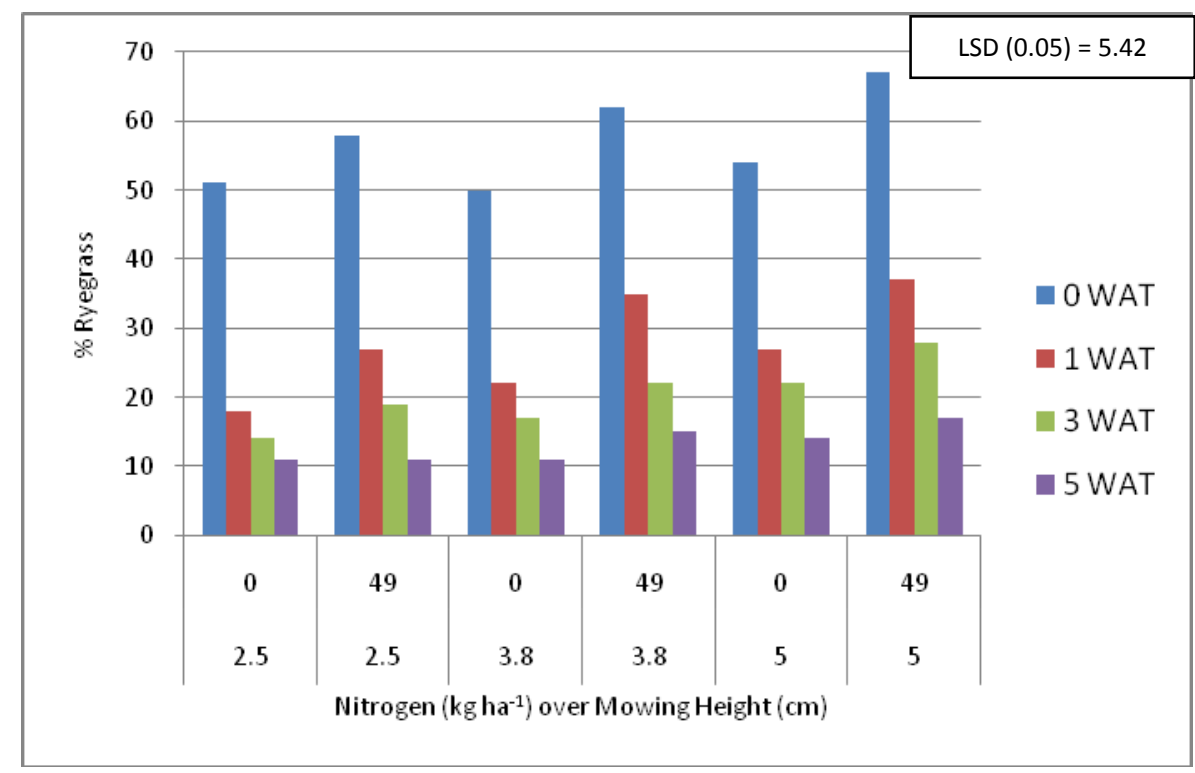

Figure 3-2. Removal of 'Transeze' perennial ryegrass from bermudagrass by mowing and application of urea fertilizer. Results were combined over three years (Columbia, MO - 2006, 2007, 2008). 


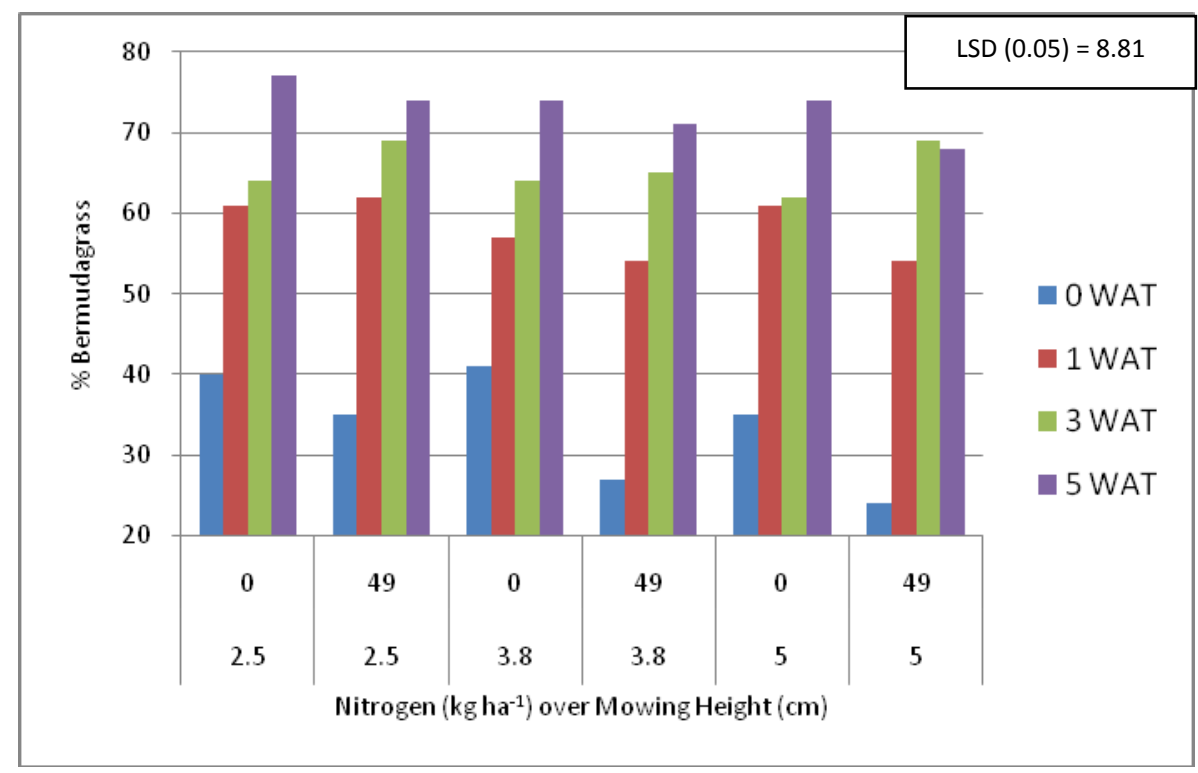

Figure 3-3. Bermudagrass recovery after removal of 'Brightstar II' perennial ryegrass by mowing and application of urea fertilizer. Results were combined over three years (Columbia, MO - 2006, 2007, 2008). 


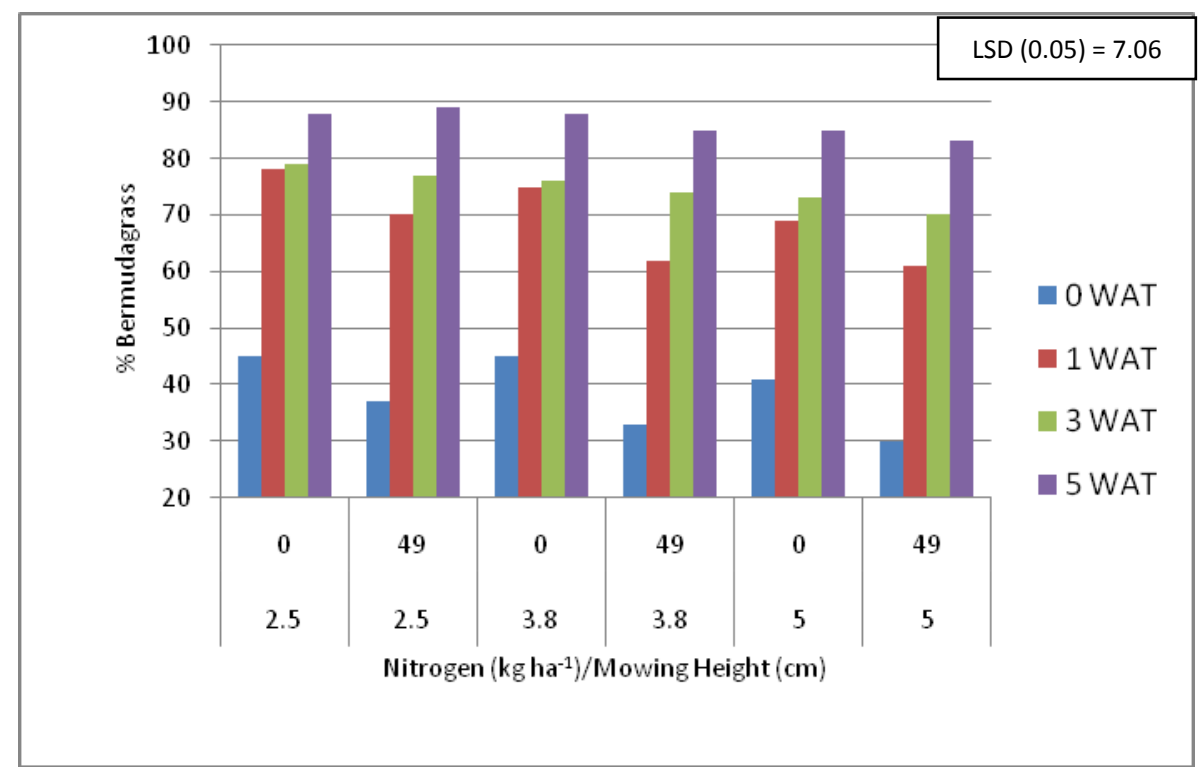

Figure 3-4. Bermudagrass recovery after removal of 'Transeze' perennial ryegrass by mowing and application of urea fertilizer. Results were combined over three years (Columbia, MO 2006, 2007, 2008). 


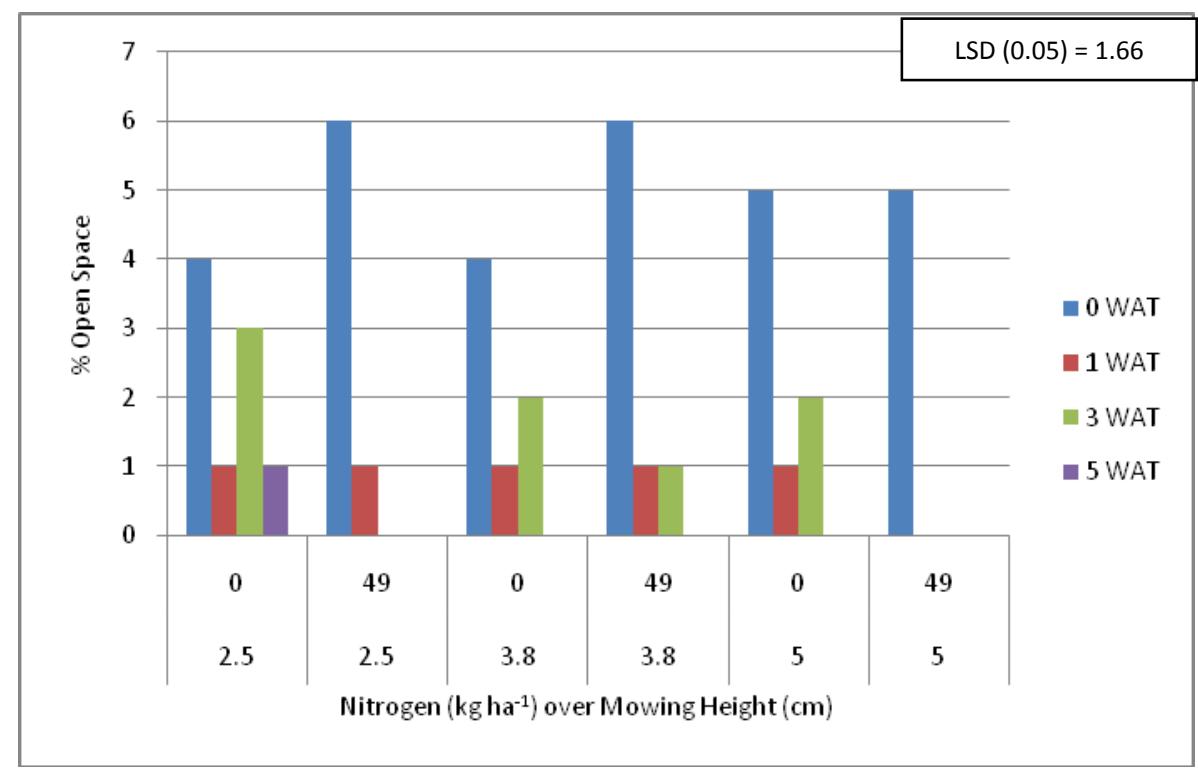

Figure 3-5. Open space during removal of 'Brightstar II' perennial ryegrass from bermudagrass by mowing and application of urea fertilizer. Results were combined over three years (Columbia, MO - 2006, 2007, 2008). 


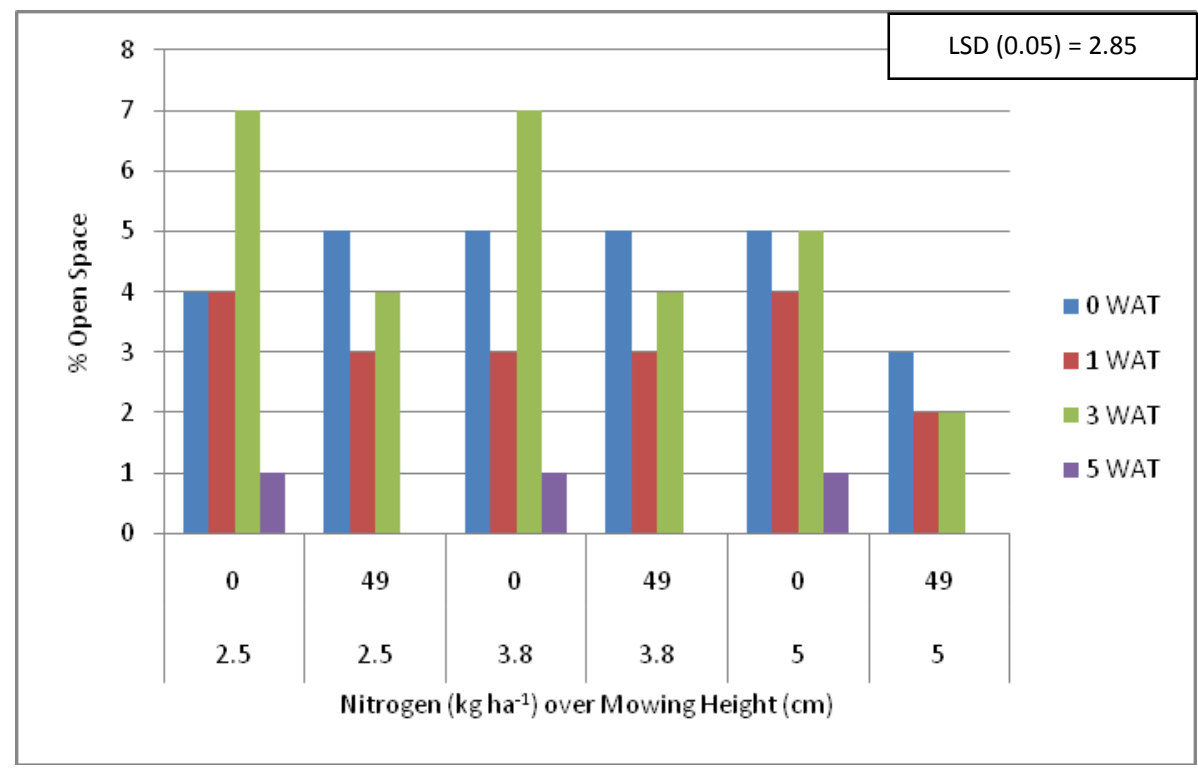

Figure 3-6. Open space during removal of 'Transeze' perennial ryegrass from bermudagrass by mowing and application of urea fertilizer. Results were combined over three years (Columbia, MO - 2006, 2007, 2008). 


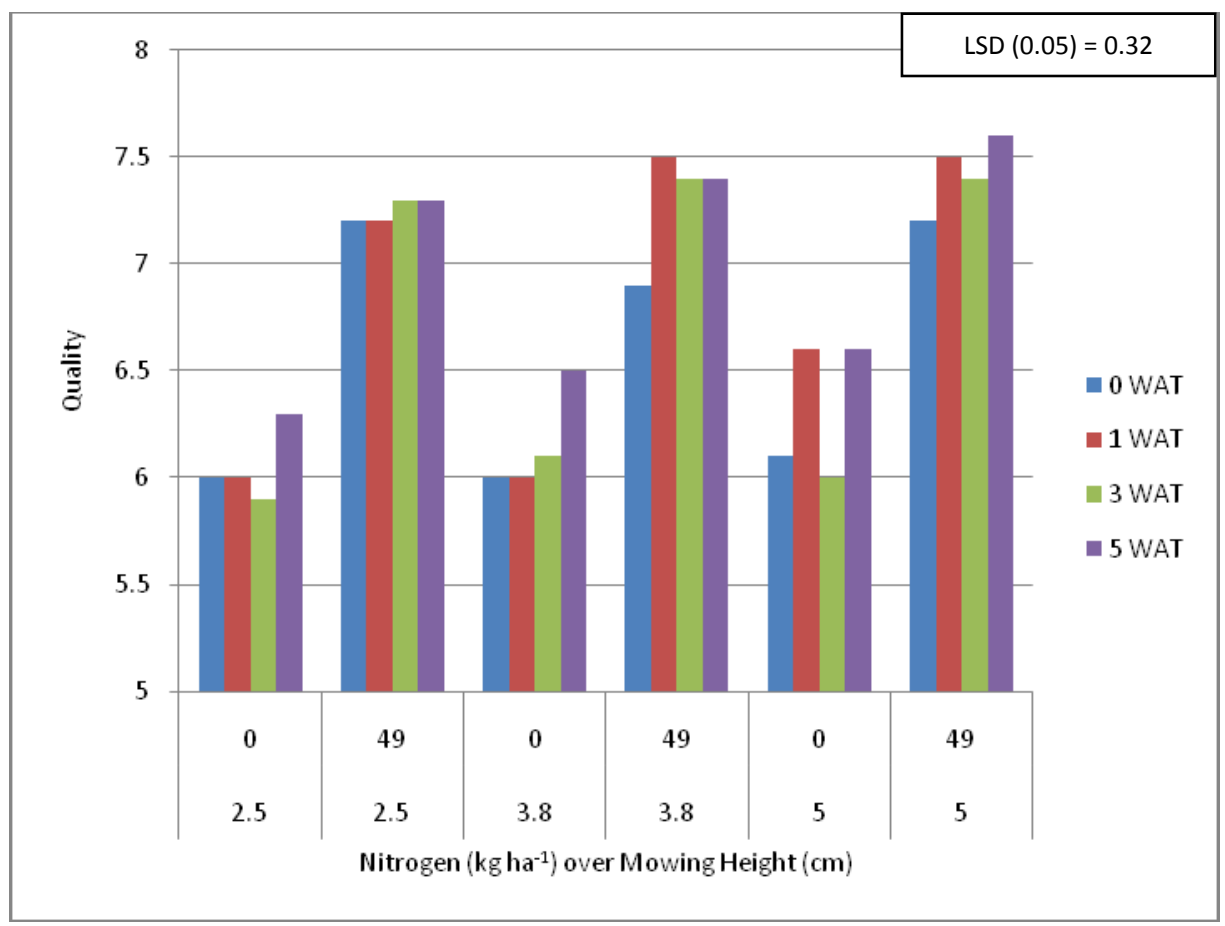

Figure 3-7. Transitional quality during removal of 'Brightstar II' perennial ryegrass from bermudagrass by mowing and application of urea fertilizer. Results were combined over three years (Columbia, MO - 2006, 2007, 2008). 


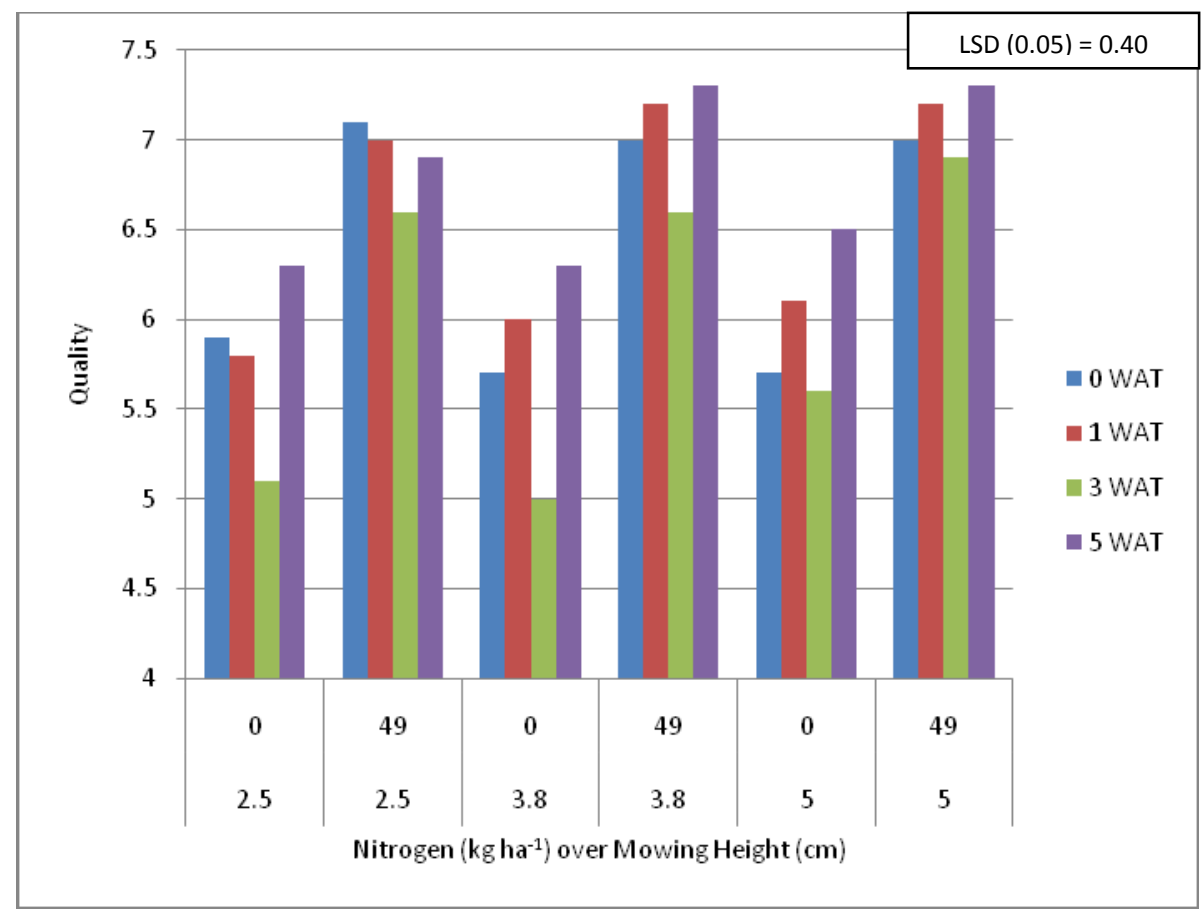

Figure 3-8. Transitional quality during removal of 'Transeze' perennial ryegrass from bermudagrass by mowing and application of urea fertilizer. Results were combined over three years (Columbia, MO - 2006, 2007, 2008). 


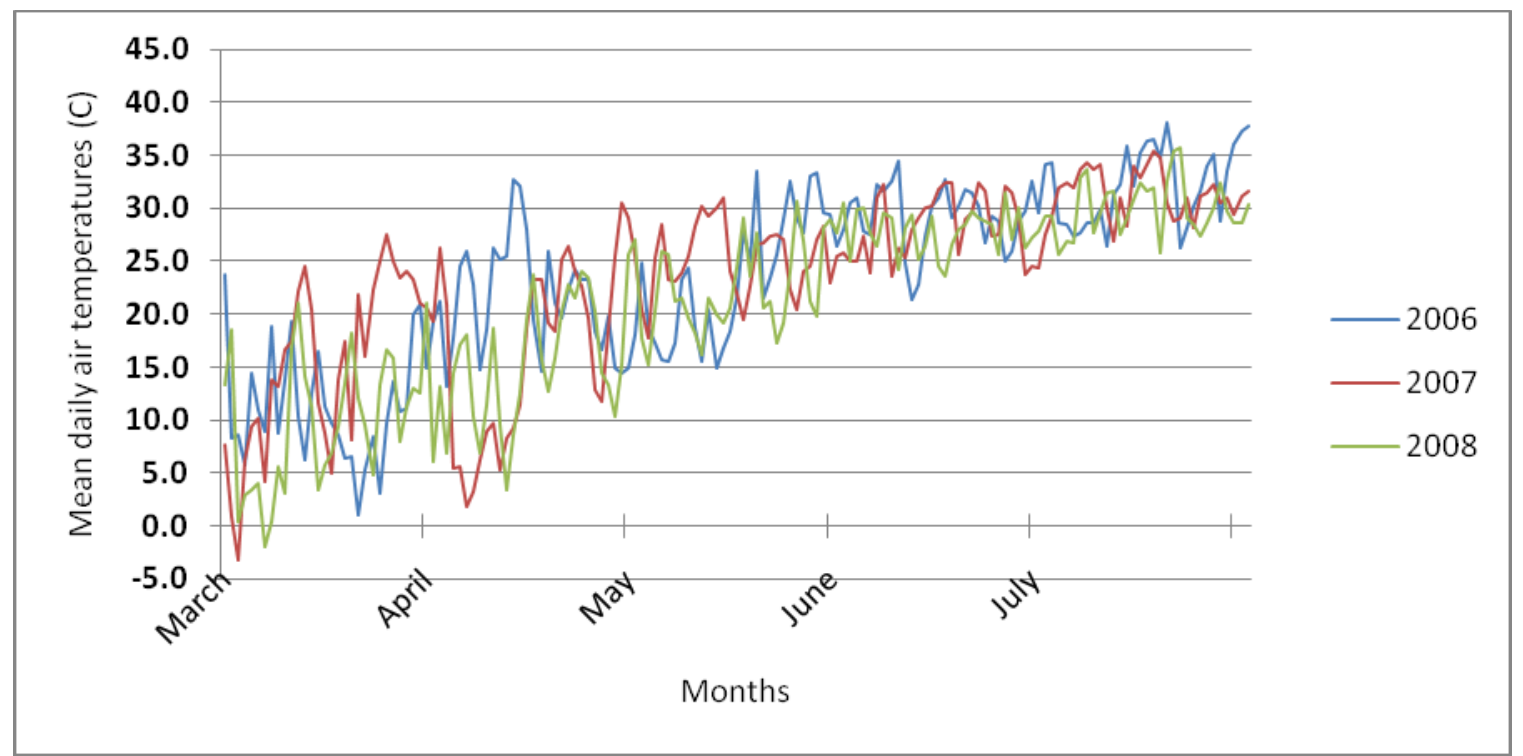

Figure 3-9. Average maximum daily temperature during spring transition in Columbia, MO over three years $(2006,2007$, and 2008). 


\section{Chapter 4}

\section{Spring Removal of Intermediate and Perennial Ryegrass (Lolium spp.) from Bermudagrass (Cynodon dactylon L. Pers.) Using Herbicides ${ }^{1}$}

\section{Brad S. Fresenburg and Reid J. Smeda ${ }^{2}$}

Abstract: To maintain green color throughout the year, bermudagrass (Cynodon dactylon L. Pers.) athletic fields in the Transition Zone are commonly over-seeded with perennial (Lolium perenne L.) or intermediate (Lolium multiflorum Lam. x Lolium perenne L.) ryegrass in early fall. However, ryegrass growth competes with spring growth of bermudagrass and ryegrass is difficult to selectively remove. The objective of this research was to remove over-seeded perennial and intermediate ryegrasses in bermudagrass using selective herbicides. Herbicides included: chlorsulfuron at $105 \mathrm{~g}$ ai $\mathrm{ha}^{-1}$, rimsulfuron at $35 \mathrm{~g}$ ai ha ${ }^{-1}$, metsulfuron at $21 \mathrm{~g}$ ai ha $^{-1}$, trifloxysulfuron at $17 \mathrm{~g}$ ai ha-

${ }^{1}$, foramsulfuron at $29 \mathrm{~g}$ ai ha ${ }^{-1}$, and sulfosulfuron at $105 \mathrm{~g}$ ai ha $^{-1}$. Significant reductions (>95\%) in ryegrass cover with all herbicides were observed on 'Brightstar II' and 'Evening Shade' (perennial) as well as 'Transeze' and 'QuickTrans' (intermediate) ryegrass over a 5 week period following application. Untreated control plots exhibited up to 22 percent ryegrass over the course of the experiment. Bermudagrass density increased from an initial level of 40 percent to 75,80 , and $93 \%$ for evaluations at 1,3 , and 5 weeks after treatment (WAT), respectively. In the untreated control, bermudagrass density increased from $40 \%$ to 61,67 , and 84 percent cover at the 1,3 , and 5 WAT evaluations, respectively. All ryegrass cultivars treated with herbicides transitioned quickly compared to the untreated control, which created significant open space (up to $25 \%$ ) in the turf canopy. Sulfonylurea herbicides are an excellent tool for the removal of 
over-seeded ryegrasses to promote complete recovery of bermudagrass during spring transition. A combination of herbicide applications and the use of intermediate ryegrasses will ensure complete removal of ryegrass and allow full recovery of bermudagrass; a rapid rate of ryegrass removal may lower transitional quality. ${ }^{1}$ Received for publication ___ and in revised form

${ }^{2}$ Extension/Research Associate, Associate Professor, Division of Plant Sciences, University of Missouri, Columbia, MO 65211, University of Missouri, Columbia, MO 65211. Email address: fresenburgb@missouri.edu.

Nomenclature: Bermudagrass (Cynodon dactylon L. Pers.) 'Riviera’; perennial ryegrass (Lolium perenne L.) 'Brightstar II', 'Evening Shade'; intermediate ryegrass (Lolium multiforum Lam. x Lolium perenne L.) ‘Transeze', 'QuickTrans’; chlorsulfuron; foramsulfuron; metsulfuron; rimsulfuron; sulfosulfuron; trifloxysulfuron.

Additional Index Words: ALS inhibiting herbicides, over-seeding. Abbreviations: WAT, weeks after treatment; ALS, acetolactate synthase. 


\section{Introduction}

Prior to the onset of dormancy, bermudagrass (Cynodon dactylon L. Pers.) athletic fields in the Transition Zone of the United States are commonly over-seeded with perennial ryegrass (Lolium perenne L.) in the fall. Over-seeding bermudagrass with ryegrass provides a year-round green surface to ensure a more uniform surface for fall, winter and early spring sports (Mazur and Wagner, 1987; McElroy, 2006). Removal of ryegrass in early spring is important to prevent formation of "clumpy rye", which impacts playability (Mazur and Wagner, 1987). Timely removal of ryegrass also ensures adequate time for bermudagrass recovery. If bermudagrass does not have sufficient time (100 days) to grow during summer months without competition from perennial ryegrass, bermudagrass stands will decline over time (Yelverton, 2005).

Turfgrass managers have relied on combinations of cultural practices to transition golf courses and athletic fields from ryegrass back to bermudagrass. These practices include lower mowing heights to allow better light penetration into the turf canopy, vertical slicing and core cultivation to warm the soil and stimulate bermudagrass growth, and the use of high nitrogen rates per application $\left(49 \mathrm{~kg} \mathrm{~N} \mathrm{ha}^{-1}\right)$ to desiccate the ryegrass tissue (McCarty, 2001). Success of spring transition is also dependent upon spring weather (Beard, 2002; USGA Report, 2004). Cooler spring weather in northern areas of the Transition Zone favors perennial ryegrass at a time when bermudagrass requires warm temperatures to initiate spring growth. Also, perennial ryegrass cultivars preclude complete transition when using cultural practices alone (Yelverton, 2005; Mazur, 1993) due to improved ryegrass persistence in warmer temperatures. The result is continued 
competition with bermudagrass during recovery (Horgan and Yelverton, 2001; Yelverton, 2005).

Increased persistence of ryegrasses has resulted in greater reliance upon herbicides for spring removal. Horgan and Yelverton (1998) stated that pronamide $\left(\operatorname{Kerb}^{\circledR}\right)$ was the optimum treatment for complete perennial ryegrass transition, although approximately eight weeks was necessary for effective control. This was prior to the large selection of sulfonylurea herbicides available today. To facilitate a smooth (lack of open space) transition to bermudagrass with pronamide, applications were required six to eight weeks before onset of growth or greenup of bermudagrass.

Umeda and Towers (2004) examined seven sulfonylurea herbicides for spring transition. In six unique field experiments, flazasulfuron, foramsulfuron, rimsulfuron, trifloxysulfuron, and chlorsulfuron were effective in removing most of the perennial ryegrass $(<8 \%$ remaining) 56 days after treatment. Sulfosulfuron and metsulfuron were least effective in removing ryegrass; only slight reductions occurred relative to the untreated control.

Recent introduction of intermediate ryegrasses (Lolium multiforum Lam. X Lolium perenne L.) have improved spring removal of ryegrass from bermudagrass (Turgeon, 2002). Intermediate ryegrasses exhibit the desirable characteristics of a perennial ryegrass, but the behavioral characteristics of an annual ryegrass (Lolium multiforum L.) (Turgeon, 2002). Annual characteristics include complete removal of ryegrass during spring transition to bermudagrass which leads to increased consideration of this new species for fall over-seeding. 
Previous use of sulfonylurea herbicides for transitioning ryegrass has focused on the removal of ryegrass, but little research has focused on the impact to bermudagrass recovery or transitional quality. Transitional quality is an introduced term that takes into consideration how smooth the transition was from ryegrass to bermudagrass.

Transitional quality also considers how well bermudagrass recovers (density) without the existence of ryegrass. However, key to this discussion on transitional quality is the length of time open space, in the canopy, remains open. Therefore, the first objective of this research was to evaluate the removal of over-seeded perennial and intermediate ryegrasses from bermudagrass with applications of chlorsulfuron, foramsulfuron, metsulfuron, rimsulfuron, sulfosulfuron, and trifloxysulfuron. The second objective of this research was to evaluate transitional quality and bermudagrass recovery in response to applied herbicides.

\section{Materials and Methods}

An area was established with 'Riviera' bermudagrass at the Turfgrass Research facility near Columbia, MO. The soil type was a 'Mexico' silt loam soil (fine, smectitie, mesic, Aeric Vertic Epiaqualfs) with $\mathrm{pH}$ of 6.1 and organic matter of $1.8 \%$. Within this area of bermudagrass, four individual blocks ( $9.7 \mathrm{~m}$ by $14.6 \mathrm{~m})$ of 'Brightstar II', 'Evening Shade', 'Transeze', and 'QuickTrans' were over-seeded in September (28, 23, and 15) in 2005, 2006, and 2007, respectively. 'Brightstar II' and 'Evening Shade' perennial ryegrasses were seeded at $3.6 \mathrm{~kg} 93 \mathrm{~m}^{-2}$ and 'Transeze' and 'QuickTrans'

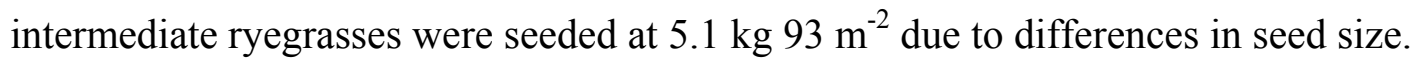
Irrigation was applied as needed to ensure uniform germination and establishment. 
Turfgrasses were mowed twice weekly at $3.8 \mathrm{~cm}$ for the duration of the experiment with a zero-turn rotary mower. Herbicide applications (Table 4-1) were applied May 26, 2006, May 21, 2007, and May 16, 2008. Herbicide treatments were designed as a randomized complete block within each block of ryegrass.

Herbicides were applied to plots sized 1.8 by $2.4 \mathrm{~m}$ and replicated four times. All treatments were applied with a $\mathrm{CO}_{2}$ pressurized backpack sprayer delivering $1871 \mathrm{ha}^{-1}$ of water at 30 psi through a Teejet ${ }^{10}$ XR8002 spray tip. A non-ionic surfactant ${ }^{3}$ at $0.50 \%$ $\mathrm{v} / \mathrm{v}$ was used with all herbicides, except foramsulfuron. Rates selected for each herbicide were based on label recommendations for ryegrass removal. Application timing of herbicides coincided with soil temperatures reaching $16.5 \mathrm{C}$ at $10 \mathrm{~cm}$. (Beard, 2002). To ensure bermudagrass recovery, all plots received $49 \mathrm{~kg}$ nitrogen $\mathrm{ha}^{-1}$ in the form of urea (46-0-0) at 1 week after treatment (WAT).

Transition from ryegrass to bermudagrass was evaluated by counting species at $0,1,3$, and 5 WAT using a modified point-quadrant system, then converting counts for each species to a scale of 0 to $100 \%$ (Laycock and Canaway, 1980). Essentially, bermudagrass, ryegrass or open spaces were assigned to each of ten points sampled per plot; a total of 50 samples were recorded per evaluation timing. Transitional quality estimated at $0,1,3$, and 5 WAT on a scale of 1 to 9 , with 1 indicating poor quality and 9 being equivalent to the highest quality (Skogley and Sawyer, 1992). Quality ratings of 6 or greater are considered acceptable(Skogley and Sawyer, 1992). Transition quality was based on canopy uniformity including green color and high density (no open space) of bermudagrass and perennial or intermediate ryegrass.

\footnotetext{
${ }^{10}$ Spraying Systems Co., P.O. Box 7900, Wheaton, IL 60187
} 
Data were analyzed as a randomized complete block design in $\mathrm{SAS}^{11}$ in which treatment represented herbicides. Lacking a significant interaction of time with treatment variable, results were pooled prior to analysis. A separate analysis was performed for each cultivar by time. Mean differences were determined using Fisher's Least Significant Difference (LSD) at the 0.05 level of probability.

\section{Results and Discussion}

All herbicide treatments resulted in greater than $95 \%$ reduction in ryegrass density with all species from 0 to 5 WAT (Tables 4-2 to 4-5) compared to the untreated control. Teuton et al. (2007) reported that single applications of sulfonylurea herbicides (foramsulfuron, metsulfuron, trifloxysulfuron, and rimsulfuron) provided $>84 \%$ control of ryegrass; however those results required 8 weeks. He also reported excellent control of ryegrass greater than 99\% with sequential applications. Umeda and Towers (2004) had similar results from applications of foramsulfuron, rimsulfuron, trifloxysulfuron, and chlorsulfuron with less than $8 \%$ ryegrass remaining after 56 days. All untreated controls in our trials had up to $22 \%$ ryegrass remaining by 5 WAT (Tables 4-2 to 4-5; Figures 4-1 to $4-4)$.

Once ryegrass is completely removed from bermudagrass in the spring, recovery of bermudagrass can proceed without competition. Of all ryegrass species, 'Transeze' intermediate ryegrass was the only species to have complete transition by 5 WAT and allow bermudagrass to recover to nearly full coverage ( $>94 \%)$ for all herbicide treatments (Table 4-4, Figure 4-3). Recovery is defined as complete bermudagrass cover and the development of rhizomes and stolons (Yelverton, 2005).

${ }^{11}$ SAS Institute, Cary, NC 27513 
'Brightstar II' perennial ryegrass (up to 4\% remaining; Table 4-2), 'Evening Shade' perennial ryegrass (up to 3\% remaining; Table 4-3), and 'QuickTrans' intermediate ryegrass (up to 3\% remaining; Table 4-5) exhibited incomplete transition by 5 WAT for most herbicide treatments. Chlorsulfuron resulted in complete removal of 'Brightstar II' perennial ryegrass (0), and had the greatest bermudagrass recovery (97\%) with minimal open space ( $3 \%$ ) by 5 WAT compared to the intermediate ryegrasses. While all ryegrass species have some natural transitional characteristics, incomplete transition leads to stronger ryegrass plants (referred to as "clumpy" ryegrass) (Yelverton, 2003), which shade and weaken bermudagrass. Fall, overseeded ryegrasses that survive spring transition become even more difficult to control with herbicides; resultant turfgrass disrupts uniformity and playability on golf courses and athletic fields (Yelverton, 2003).

All herbicide treatments improved the spring recovery of bermudagrass compared to the untreated control. Bermudagrass density increased from an initial level of $40 \%$ to 75,80 , and $93 \%$ for evaluations at 1,3 , and 5 WAT, respectively (Tables 4-2 to 4-5). The untreated control increased from $40 \%$ cover to 61,67 , and $84 \%$ for evaluations at 1 , 3 , and 5 WAT, respectively (Tables 4-2 to 4-5). All herbicide treatments resulted in excellent control (> 95\%) of each ryegrass cultivar by 5 WAT, thereby permitting bermudagrass sufficient time for complete recovery (Table 4-10).

Open space indicates the lack of ryegrass and bermudagrass; it is desired that bermudagrass growth fill in open space as ryegrass is eliminated. While complete transition is desirable, a transition that is too rapid can produce large amounts of open space and reduce quality of the turfgrass canopy (Horgan and Yelverton, 2001). Yelverton (2004) ranked several sulfonylurea herbicides from slowest to fastest: 
metsulfuron is slower than foramsulfuron, rimsulfuron, and trifloxysulfuron. He stated that applications made too early of foramsulfuron, rimsulfuron, and trifloxysulfuron would remove perennial ryegrass too quickly; before the bermudagrass was able to fill in. All ryegrass cultivars treated with herbicides transitioned quickly compared to the untreated control, which created significant open space (up to $25 \%$ ) in the turf canopy (Tables 4-2 to 4-5; Figures 4-9 to 4-12) by 3 WAT. This amount of open space leads to poor transitional quality.

Transitional quality is an introduced term that takes into consideration how smooth (lack of open space) the transition was from ryegrass to bermudagrass. Transitional quality also considers how well bermudagrass recovers (density) without the existence of ryegrass. Lower transitional quality was observed with higher percentages of open space in the turfgrass canopy for all treatments by 3 WAT (Tables 4-6 to 4-9). However, this was transient, as bermudagrass recovered (>90\%) by 5 WAT.

Weather, especially in the Transition Zone, is an important factor in the success of turfgrass managers for spring removal of ryegrass. Spring air temperature fluctuations were observed in all years (Figure 4-13). Average maximum air temperatures for late May during 2006 and 2008 dropped to nearly 15 C; in early June of 2007 and 2008 air temperature dropped to nearly $20 \mathrm{C}$ (Figure 4-13). Cooler air temperatures slow bermudagrass recovery and have a negative effect on ryegrass removal (Beard, 2002; USGA Report, 2004). Herbicide removal of ryegrasses becomes a desirable option when ryegrass removal by cultural practices is slowed by cooler air temperatures.

Sulfonylurea herbicides are an excellent tool for golf course superintendents and sports turf managers to remove over-seeded ryegrasses and promote complete recovery of 
bermudagrass during spring transition. Combining herbicide applications with the use of intermediate ryegrasses will ensure complete removal of ryegrass and allow full recovery of bermudagrass; the rapid removal of intermediate ryegrass can transiently lower transitional quality by leaving an unacceptable amount of open space. 


\section{Literature Cited}

Askew, S.D., J.B. Beam, and W.L. Barker. 2003. Control of over-seeded ryegrass on bermudagrass fairways with trifloxysulfuron sodium. Northeastern Weed Sci Soc. Proc. $57: 110$.

Beard, J.B. 2002. Turf Management for Golf Courses. Second Edition. Ann Arbor Press. Chelsea, Michigan.

Devine, M., S.O. Duke, and C. Fedtke. 1993. Physiology of herbicide action. PrenticeHall Inc., Upper Saddle River, New Jersey.

Horgan, B. and F. Yelverton. How to kill perennial ryegrass in over-seeded fairways. Golf Course Management. August 1998.

Horgan, B.P. and F.H. Yelverton. 2001. Removal of perennial ryegrass from over-seeded bermudagrass using cultural methods. Crop Sci. 41:118-126.

Hutto, K.C., J.M. Taylor, and J.D. Byrd, Jr. 2008. Soil temperatures as an application indicator for perennial ryegrass control. Weed Technology: Vol. 22, No. 2, pp 245-248.

Laycock, R.W. and P.M. Canaway. 1980. A new optical point quadrant frame for the estimation of cover in close mowed turf. pp. 91-92. Journal of the Sports Turf Institute, Sports Turf Research Institute.

Mazur, A. R. and D. F. Wagner. 1987. Influence of aeration, topdressing, and vertical mowing on over-seeded bermudagrass putting green turf. HortScience 22:1276-1278.

McCarty, L.B. 2001. Best Golf Course Management Practices. Prentice Hall. Upper Saddle River, New Jersey.

McElroy, S. 2006. Overseeding bermudagrass: chemical vs natural transition. Sports Turf. February 2006. pp. 8.

National Weather Service. 2010. NOAA, 1325 East West Highway, Silver Spring, MD 20910

Peterson, R.G. 1994. Agricultural Field Experiments: Design and Analysis. Marcel Dekker, Inc., New York, New York.

Skogley, C.R. and C.D. Sawyer. 1992. Field Research. P. 589-614. In D.V. Waddington et al (ed.) Turfgrass Agron. Monogr. 32. ASA, CSSA, and SSSA, Madison, WI.

Teuton, T.C., C.L. Main, J.C. Sorochan, J.S. McElroy, and T.C. Mueller. 2007. Evaluation of ALS-Inhibiting Herbicides for Removal of Overseeded Perennial Ryegrass. Unpublished manuscript from dissertation, University of Tennessee. 
Turgeon, A.J. 2002. Turfgrass Management. Sixth Edition. Prentice Hall. Upper Saddle River, New Jersey.

Yelverton, F. A new herbicide for weeds in bermudagrass and zoysiagrass. Golf Course Management. May 2003: 119-122.

Yelverton, F. 2004. New weed control in warm season grasses. Golf Course Management. 72:203-206.

Yelverton, F. Spring transition: Going, going, gone. United States Golf Association. Greens Section Record. March/April 2005. 
Table 4-1. Herbicide names and rates (206, 2007, and 2008).

\begin{tabular}{llcc} 
Common name & Product name & Product $\left(\mathrm{g} \mathrm{ha}^{-1}\right)$ & $\begin{array}{c}\text { Active } \\
\text { Ingredient }\left(\mathrm{g} \mathrm{ai} \mathrm{ha}^{-1}\right)\end{array}$ \\
\hline Chlorsulfuron & Corsair 75WG & 140 & 105 \\
Rimsulfuron & TranXit 25WG & 140 & 35 \\
Metsulfuron & Manor/Blade 60WG & 35 & 21 \\
Trifloxysulfuron & Monument 75WDGTM & 23 & 17 \\
Foramsulfuron & Revolver 0.19 SC & $1.27^{\mathrm{T}}$ & 29 \\
Sulfosulfuron & Certainty 75WG & 140 & 105
\end{tabular}


Table 4-2. Effect of herbicide applications on 'Brightstar II' perennial ryegrass and bermudagrass densities with resultant open space. Results were combined over three years, (Columbia, MO - 2006, 2007, 2008).

\begin{tabular}{|c|c|c|c|c|c|c|c|c|c|c|c|c|c|}
\hline \multirow[b]{2}{*}{ Treatment } & \multirow[b]{2}{*}{ g ai ha ${ }^{-1}$} & \multicolumn{4}{|c|}{ Ryegrass } & \multicolumn{4}{|c|}{ Bermudagrass } & \multicolumn{4}{|c|}{ Open Space } \\
\hline & & $0 \mathrm{WAT}^{\mathrm{b}}$ & $1 \mathrm{WAT}$ & $3 \mathrm{WAT}$ & 5WAT & 0WAT & $1 \mathrm{WAT}$ & 3WAT & $5 \mathrm{WAT}$ & 0WAT & $1 \mathrm{WAT}$ & $3 \mathrm{WAT}$ & $5 \mathrm{WAT}$ \\
\hline Untreated control & - & $66 \mathrm{~b}$ & $47 \mathrm{a}$ & $34 \mathrm{a}$ & $15 \mathrm{a}$ & $34 \mathrm{a}$ & $53 \mathrm{~b}$ & $65 \mathrm{~b}$ & $83 \mathrm{c}$ & 0 & 0 & $1 \mathrm{c}$ & $2 \mathrm{a}$ \\
\hline Chlorsulfuron & 105 & $63 \mathrm{~b}$ & $31 \mathrm{~b}$ & $6 \mathrm{~b}$ & $0 \mathrm{c}$ & $37 \mathrm{a}$ & $69 a$ & $86 a$ & $97 \mathrm{a}$ & 0 & 0 & $8 \mathrm{~b}$ & $3 \mathrm{a}$ \\
\hline Rimsulfuron & 35 & $74 \mathrm{a}$ & $35 \mathrm{~b}$ & $6 \mathrm{~b}$ & $2 \mathrm{bc}$ & $26 \mathrm{~b}$ & $65 \mathrm{a}$ & $82 \mathrm{a}$ & $94 \mathrm{ab}$ & 0 & 0 & $13 \mathrm{a}$ & $4 \mathrm{a}$ \\
\hline Metsulfuron & 21 & $70 \mathrm{ab}$ & $36 \mathrm{ab}$ & $6 \mathrm{~b}$ & $4 \mathrm{~b}$ & $30 \mathrm{ab}$ & $64 \mathrm{ab}$ & $85 \mathrm{a}$ & $93 \mathrm{~b}$ & 0 & 0 & $10 \mathrm{ab}$ & $3 \mathrm{a}$ \\
\hline Trifloxysulfuron & 17 & $69 a b$ & $37 \mathrm{ab}$ & $8 \mathrm{~b}$ & $4 \mathrm{~b}$ & $31 \mathrm{ab}$ & $63 a b$ & 86 a & $92 \mathrm{~b}$ & 0 & 0 & $7 \mathrm{~b}$ & $4 \mathrm{a}$ \\
\hline Foramsulfuron & 29 & $69 a b$ & $29 \mathrm{~b}$ & $6 \mathrm{~b}$ & $3 \mathrm{~b}$ & $32 a b$ & $71 \mathrm{a}$ & $84 \mathrm{a}$ & $93 \mathrm{~b}$ & 0 & 0 & $9 \mathrm{~b}$ & $4 \mathrm{a}$ \\
\hline Sulfosulfuron & 105 & $69 \mathrm{ab}$ & $35 \mathrm{~b}$ & $8 \mathrm{~b}$ & $4 \mathrm{~b}$ & $31 \mathrm{ab}$ & $65 \mathrm{a}$ & $83 \mathrm{a}$ & $92 \mathrm{~b}$ & 0 & 0 & $9 \mathrm{~b}$ & $4 \mathrm{a}$ \\
\hline$\overline{\operatorname{LSD}(0.05)^{\mathrm{c}}}$ & & 7 & 12 & 4 & 3 & 7 & 12 & 5 & 4 & - & - & 4 & 3 \\
\hline
\end{tabular}

${ }^{a}$ Counts: Number of plants (ryegrass or bermudagrass) or open space per 100 counts.

${ }^{\mathrm{b}}$ WAT: Weeks After Treatment.

${ }^{c}$ Fisher's Least Significant Difference (LSD) at the 0.05 level of probability. 
Table 4-3. Effect of herbicide applications on 'Evening Shade' perennial ryegrass and bermudagrass densities with resultant open space. Results were combined over three years, (Columbia, MO - 2006, 2007, 2008).

\begin{tabular}{|c|c|c|c|c|c|c|c|c|c|c|c|c|c|}
\hline \multirow[b]{2}{*}{ Treatment } & \multirow[b]{2}{*}{ g ai ha ${ }^{-1}$} & \multicolumn{4}{|c|}{ Ryegrass } & \multicolumn{4}{|c|}{ Bermudagrass } & \multicolumn{4}{|c|}{ Open Space } \\
\hline & & $0 \mathrm{WAT}^{\mathrm{b}}$ & b 1 WAT & $3 \mathrm{WAT}$ & $5 \mathrm{WAT}$ & 0WAT & $1 \mathrm{WAT}$ & $3 \mathrm{WAT}$ & 5WAT & 0WAT & $1 \mathrm{WAT}$ & 3WAT & 5WAT \\
\hline Untreated control & - & $59 \mathrm{a}$ & $37 \mathrm{a}$ & $29 \mathrm{a}$ & $18 \mathrm{a}$ & $39 a$ & $63 \mathrm{~b}$ & $69 \mathrm{~b}$ & $81 \mathrm{a}$ & $2 \mathrm{~b}$ & 0 & $2 \mathrm{~b}$ & $1 \mathrm{~b}$ \\
\hline Chlorsulfuron & 105 & $60 \mathrm{a}$ & $26 \mathrm{~b}$ & $3 \mathrm{bc}$ & $3 \mathrm{~b}$ & $37 \mathrm{a}$ & $74 \mathrm{a}$ & $72 \mathrm{ab}$ & $87 \mathrm{a}$ & $3 \mathrm{ab}$ & 0 & $25 \mathrm{a}$ & $11 \mathrm{a}$ \\
\hline Rimsulfuron & 35 & $61 \mathrm{a}$ & $65 \mathrm{~b}$ & $4 \mathrm{~b}$ & $2 \mathrm{~b}$ & $38 \mathrm{a}$ & $75 \mathrm{a}$ & $75 \mathrm{ab}$ & $88 \mathrm{a}$ & $2 \mathrm{~b}$ & 0 & $22 \mathrm{a}$ & $10 \mathrm{a}$ \\
\hline Metsulfuron & 21 & $59 a$ & $27 \mathrm{~b}$ & $2 \mathrm{c}$ & $2 \mathrm{~b}$ & $39 \mathrm{a}$ & $73 \mathrm{a}$ & $80 \mathrm{a}$ & $90 \mathrm{a}$ & $2 \mathrm{~b}$ & 0 & $18 \mathrm{a}$ & $9 \mathrm{ab}$ \\
\hline Trifloxysulfuron & 17 & $60 a$ & $23 \mathrm{~b}$ & $3 \mathrm{bc}$ & $3 \mathrm{~b}$ & $36 a$ & $77 \mathrm{a}$ & $76 \mathrm{ab}$ & $88 \mathrm{a}$ & $4 \mathrm{a}$ & 0 & $21 \mathrm{a}$ & $9 \mathrm{ab}$ \\
\hline Foramsulfuron & 29 & $63 \mathrm{a}$ & $23 \mathrm{~b}$ & $2 \mathrm{c}$ & $2 \mathrm{~b}$ & $37 \mathrm{a}$ & $77 \mathrm{a}$ & $80 \mathrm{a}$ & $89 a$ & $1 \mathrm{~b}$ & 0 & $18 \mathrm{a}$ & $9 \mathrm{ab}$ \\
\hline Sulfosulfuron & 105 & $60 a$ & $23 \mathrm{~b}$ & $2 \mathrm{c}$ & $2 \mathrm{~b}$ & $38 \mathrm{a}$ & $77 \mathrm{a}$ & $79 a$ & $89 a$ & $2 \mathrm{~b}$ & 0 & $19 \mathrm{a}$ & $9 \mathrm{ab}$ \\
\hline $\operatorname{LSD}(0.05)^{\mathrm{c}}$ & & 8 & 6 & 2 & 3 & 9 & 6 & 9 & 9 & 2 & - & 9 & 9 \\
\hline
\end{tabular}

${ }^{a}$ Counts: Number of plants (ryegrass or bermudagrass) or open space per 100 counts.

${ }^{\mathrm{b}}$ WAT: Weeks After Treatment.

${ }^{c}$ Fisher's Least Significant Difference (LSD) at the 0.05 level of probability. 
Table 4-4. Effect of herbicide applications on 'Transeze' intermediate ryegrass and bermudagrass densities with resultant open space. Results were combined over three years, (Columbia, MO - 2006, 2007, 2008).

\begin{tabular}{|c|c|c|c|c|c|c|c|c|c|c|c|c|c|}
\hline \multirow[b]{2}{*}{ Treatment } & \multirow[b]{2}{*}{ g ai ha ${ }^{-1}$} & \multicolumn{4}{|c|}{ Ryegrass } & \multicolumn{4}{|c|}{ Bermudagrass } & \multicolumn{4}{|c|}{ Open Space } \\
\hline & & $0 \mathrm{WAT}^{\mathrm{b}}$ & b $1 \mathrm{WAT}$ & 3WAT & 5WAT & 0WAT & 1WAT & 3WAT & $5 \mathrm{WAT}$ & 0WAT & $1 \mathrm{WAT}$ & $3 \mathrm{WAT}$ & 5WAT \\
\hline Untreated control & - & $52 \mathrm{a}$ & $35 \mathrm{a}$ & $34 \mathrm{a}$ & $5 \mathrm{a}$ & $45 \mathrm{a}$ & $65 \mathrm{c}$ & $66 \mathrm{c}$ & $94 \mathrm{a}$ & $2 \mathrm{a}$ & $0 \mathrm{c}$ & $0 \mathrm{c}$ & $1 \mathrm{~b}$ \\
\hline Chlorsulfuron & 105 & $51 \mathrm{a}$ & $19 b$ & $1 \mathrm{~b}$ & $0 \mathrm{~b}$ & $48 \mathrm{a}$ & $77 \mathrm{ab}$ & $82 \mathrm{ab}$ & $96 \mathrm{a}$ & $2 \mathrm{a}$ & $4 a b$ & $17 \mathrm{ab}$ & $4 a b$ \\
\hline Rimsulfuron & 35 & $54 \mathrm{a}$ & $16 \mathrm{~b}$ & $1 \mathrm{~b}$ & $0 \mathrm{~b}$ & $51 \mathrm{a}$ & $81 \mathrm{ab}$ & $77 \mathrm{~b}$ & $94 \mathrm{a}$ & $2 \mathrm{a}$ & $4 \mathrm{ab}$ & $22 \mathrm{a}$ & $6 \mathrm{a}$ \\
\hline Metsulfuron & 21 & $54 \mathrm{a}$ & $22 \mathrm{~b}$ & $2 b$ & $0 \mathrm{~b}$ & $45 \mathrm{a}$ & $75 \mathrm{~b}$ & $84 \mathrm{a}$ & $98 \mathrm{a}$ & $1 \mathrm{a}$ & $3 \mathrm{~b}$ & $14 \mathrm{~b}$ & $2 \mathrm{~b}$ \\
\hline Trifloxysulfuron & 17 & $50 \mathrm{a}$ & $18 \mathrm{~b}$ & $2 \mathrm{~b}$ & $0 \mathrm{~b}$ & $48 \mathrm{a}$ & $76 \mathrm{ab}$ & $84 \mathrm{a}$ & $98 \mathrm{a}$ & $2 \mathrm{a}$ & $6 \mathrm{a}$ & $14 \mathrm{~b}$ & $2 \mathrm{~b}$ \\
\hline Foramsulfuron & 29 & $51 \mathrm{a}$ & $16 \mathrm{~b}$ & $1 \mathrm{~b}$ & $0 \mathrm{~b}$ & $47 \mathrm{a}$ & $82 \mathrm{a}$ & $82 \mathrm{ab}$ & $98 \mathrm{a}$ & $2 \mathrm{a}$ & $3 \mathrm{~b}$ & $17 \mathrm{ab}$ & $3 a b$ \\
\hline Sulfosulfuron & 105 & $49 \mathrm{a}$ & $18 \mathrm{~b}$ & $1 \mathrm{~b}$ & $0 \mathrm{~b}$ & $49 \mathrm{a}$ & $79 \mathrm{ab}$ & $53 \mathrm{a}$ & $96 \mathrm{a}$ & $3 \mathrm{a}$ & $3 \mathrm{~b}$ & $17 \mathrm{ab}$ & $4 \mathrm{ab}$ \\
\hline$\overline{\operatorname{LSD}(0.05)^{\mathrm{c}}}$ & & 8 & 7 & 2 & 2 & 8 & 7 & 6 & 5 & 3 & 3 & 6 & 4 \\
\hline
\end{tabular}

${ }^{a}$ Counts: Number of plants (ryegrass or bermudagrass) or open space per 100 counts.

${ }^{\mathrm{b}}$ WAT: Weeks After Treatment.

${ }^{\text {c }}$ Fisher's Least Significant Difference (LSD) at the 0.05 level of probability. 
Table 4-5. Effect of herbicide applications on 'QuickTrans' intermediate ryegrass and bermudagrass densities with resultant open space. Results were combined over three years, (Columbia, MO - 2006, 2007, 2008).

\begin{tabular}{|c|c|c|c|c|c|c|c|c|c|c|c|c|c|}
\hline \multirow[b]{2}{*}{ Treatment } & \multirow[b]{2}{*}{ g ai ha ${ }^{-1}$} & \multicolumn{4}{|c|}{ Ryegrass } & \multicolumn{4}{|c|}{ Bermuda } & \multicolumn{4}{|c|}{ Open Space } \\
\hline & & $0 \mathrm{WAT}^{\mathrm{b}}$ & $1 \mathrm{WAT}$ & $3 \mathrm{WAT}$ & 5WAT & 0WAT & 1WAT & 3WAT & 5WAT & 0WAT & 1WAT & 3WAT & 5WAT \\
\hline Untreated control & - & $57 \mathrm{a}$ & $35 \mathrm{a}$ & $30 \mathrm{a}$ & $22 \mathrm{a}$ & $42 \mathrm{a}$ & $65 \mathrm{~b}$ & $68 \mathrm{a}$ & $77 \mathrm{~b}$ & $1 \mathrm{ab}$ & 0 & $3 \mathrm{~b}$ & $1 \mathrm{~b}$ \\
\hline Chlorsulfuron & 105 & $58 \mathrm{a}$ & $22 \mathrm{~b}$ & $4 \mathrm{~b}$ & $0 \mathrm{~b}$ & $42 \mathrm{a}$ & $79 a$ & $78 \mathrm{a}$ & $92 \mathrm{a}$ & $1 \mathrm{ab}$ & 0 & $17 \mathrm{a}$ & $8 \mathrm{a}$ \\
\hline Rimsulfuron & 35 & $63 \mathrm{a}$ & $26 \mathrm{~b}$ & $7 \mathrm{~b}$ & $1 \mathrm{~b}$ & $36 \mathrm{a}$ & $74 \mathrm{a}$ & $74 \mathrm{a}$ & $92 \mathrm{a}$ & $1 \mathrm{ab}$ & 0 & $19 \mathrm{a}$ & $8 \mathrm{a}$ \\
\hline Metsulfuron & 21 & $58 \mathrm{a}$ & $21 \mathrm{~b}$ & $4 \mathrm{~b}$ & $2 \mathrm{~b}$ & $42 \mathrm{a}$ & $79 a$ & $75 \mathrm{a}$ & $90 \mathrm{a}$ & $0 \mathrm{a}$ & 0 & $20 \mathrm{a}$ & $8 \mathrm{a}$ \\
\hline Trifloxysulfuron & 17 & $59 \mathrm{a}$ & $27 \mathrm{~b}$ & $7 \mathrm{~b}$ & $3 b$ & $40 \mathrm{a}$ & $73 \mathrm{a}$ & $77 \mathrm{a}$ & $91 \mathrm{a}$ & $1 \mathrm{ab}$ & 0 & $17 \mathrm{a}$ & $7 \mathrm{ab}$ \\
\hline Foramsulfuron & 29 & $59 \mathrm{a}$ & $22 \mathrm{~b}$ & $4 \mathrm{~b}$ & $2 \mathrm{~b}$ & $40 \mathrm{a}$ & $78 \mathrm{a}$ & $79 \mathrm{a}$ & $93 \mathrm{a}$ & $1 \mathrm{ab}$ & 0 & $17 \mathrm{a}$ & $6 \mathrm{ab}$ \\
\hline Sulfosulfuron & 105 & $60 \mathrm{a}$ & $21 \mathrm{~b}$ & $4 \mathrm{~b}$ & $3 \mathrm{~b}$ & $39 \mathrm{a}$ & $80 \mathrm{a}$ & $79 \mathrm{~b}$ & $91 \mathrm{a}$ & $2 \mathrm{~b}$ & 0 & $16 \mathrm{a}$ & $6 \mathrm{ab}$ \\
\hline $\operatorname{LSD}(0.05)^{\mathrm{c}}$ & & 8 & 8 & 6 & 4 & 8 & 8 & 11 & 8 & 2 & - & 11 & 7 \\
\hline
\end{tabular}

${ }^{a}$ Counts: Number of plants (ryegrass or bermudagrass) or open space per 100 counts.

${ }^{\mathrm{b}}$ WAT: Weeks After Treatment.

${ }^{c}$ Fisher's Least Significant Difference (LSD) at the 0.05 level of probability. 
Table 4-6. Transitional quality ${ }^{\mathrm{a}}$ based on presence of 'Brightstar II' perennial ryegrass, bermudagrass, and open space. Results were combined over three years (Columbia, MO - 2006, 2007, 2008).

\begin{tabular}{|c|c|c|c|c|c|}
\hline Treatment & g ai ha ${ }^{-1}$ & $0 \mathrm{WAT}^{\mathrm{b}}$ & $1 \mathrm{WAT}$ & 3WAT & $5 \mathrm{WAT}$ \\
\hline Untreated control & - & $7.4 \mathrm{ab}$ & $7.0 \mathrm{a}$ & $6.1 \mathrm{a}$ & $6.3 \mathrm{a}$ \\
\hline Chlorsulfuron & 105 & $7.1 \mathrm{~b}$ & $6.1 \mathrm{~b}$ & $5.0 \mathrm{~b}$ & $5.8 \mathrm{ab}$ \\
\hline Rimsulfuron & 35 & $7.6 \mathrm{a}$ & $6.4 \mathrm{~b}$ & $4.1 \mathrm{c}$ & $5.8 \mathrm{ab}$ \\
\hline Metsulfuron & 21 & $7.7 \mathrm{a}$ & $6.4 \mathrm{~b}$ & $4.5 \mathrm{bc}$ & $5.7 \mathrm{~b}$ \\
\hline Trifloxysulfuron & 17 & $7.6 \mathrm{a}$ & $6.4 \mathrm{~b}$ & $4.9 \mathrm{~b}$ & $5.9 \mathrm{ab}$ \\
\hline Foramsulfuron & 29 & $7.4 \mathrm{ab}$ & $6.0 \mathrm{~b}$ & $4.7 \mathrm{bc}$ & $5.8 \mathrm{ab}$ \\
\hline Sulfosulfuron & 105 & $7.6 \mathrm{a}$ & $6.3 \mathrm{~b}$ & $4.8 \mathrm{bc}$ & $5.8 \mathrm{ab}$ \\
\hline $\operatorname{LSD}(0.05)^{\mathrm{c}}$ & & 0.4 & 0.5 & 0.8 & 0.6 \\
\hline
\end{tabular}

${ }^{\text {a }}$ Quality: Taken on a scale of 1 to 9 with 9 being equal to the highest turfgrass quality. Quality ratings of 6 or greater are considered acceptable.

${ }^{\mathrm{b}}$ WAT: Weeks After Treatment.

${ }^{\mathrm{c}}$ Fisher's Least Significant Difference (LSD) at the 0.05 level of probability. 
Table 4-7. Transitional quality ${ }^{\mathrm{a}}$ based on presence of 'Evening Shade' perennial ryegrass, bermudagrass, and open space. Results were combined over three years (Columbia, MO - 2006, 2007, 2008).

\begin{tabular}{|c|c|c|c|c|c|}
\hline Treatment & gai ha ${ }^{-1}$ & $0 \mathrm{WAT}^{\mathrm{b}}$ & $1 \mathrm{WAT}$ & $3 \mathrm{WAT}$ & $5 \mathrm{WAT}$ \\
\hline Untreated control & - & $6.4 \mathrm{a}$ & $6.9 \mathrm{a}$ & $6.0 \mathrm{a}$ & $6.5 \mathrm{a}$ \\
\hline Chlorsulfuron & 105 & $6.3 \mathrm{a}$ & $6.1 \mathrm{bc}$ & $3.1 \mathrm{~b}$ & $5.0 \mathrm{~b}$ \\
\hline Rimsulfuron & 35 & $6.3 \mathrm{a}$ & $6.1 \mathrm{bc}$ & $3.6 \mathrm{~b}$ & $5.3 \mathrm{~b}$ \\
\hline Metsulfuron & 21 & $6.3 \mathrm{a}$ & $6.0 \mathrm{c}$ & $3.8 \mathrm{~b}$ & $5.3 \mathrm{~b}$ \\
\hline Trifloxysulfuron & 17 & $6.1 \mathrm{a}$ & $6.3 \mathrm{~b}$ & $3.4 \mathrm{~b}$ & $5.2 \mathrm{~b}$ \\
\hline Foramsulfuron & 29 & $6.8 \mathrm{a}$ & $6.0 \mathrm{c}$ & $3.8 \mathrm{~b}$ & $5.3 \mathrm{~b}$ \\
\hline Sulfosulfuron & 105 & $6.6 \mathrm{a}$ & $6.1 \mathrm{bc}$ & $3.6 \mathrm{~b}$ & $5.3 \mathrm{~b}$ \\
\hline $\operatorname{LSD}(0.05)^{\mathrm{c}}$ & & 1.1 & 0.3 & 1.2 & 1.2 \\
\hline
\end{tabular}

${ }^{a}$ Quality: Taken on a scale of 1 to 9 with 9 being equal to the highest turfgrass quality. Quality ratings of 6 or greater are considered acceptable.

${ }^{\mathrm{b}}$ WAT: Weeks After Treatment.

${ }^{\mathrm{c}}$ Fisher's Least Significant Difference (LSD) at the 0.05 level of probability. 
Table 4-8. Transitional quality ${ }^{\mathrm{a}}$ based on presence of 'Transeze' intermediate ryegrass, bermudagrass, and open space. Results were combined over three years (Columbia, MO - 2006, 2007, 2008).

\begin{tabular}{|c|c|c|c|c|c|}
\hline Treatment & $\mathrm{g}$ ai ha $^{-1}$ & $0 \mathrm{WAT}^{\mathrm{b}}$ & 1WAT & $3 \mathrm{WAT}$ & $5 \mathrm{WAT}$ \\
\hline Untreated control & - & $6.3 \mathrm{a}$ & $6.6 \mathrm{a}$ & $6.7 \mathrm{a}$ & $6.0 \mathrm{a}$ \\
\hline Chlorsulfuron & 105 & $6.6 \mathrm{a}$ & $5.4 \mathrm{~b}$ & $3.9 \mathrm{~b}$ & $5.7 \mathrm{ab}$ \\
\hline Rimsulfuron & 35 & $6.2 \mathrm{a}$ & $5.1 \mathrm{~b}$ & $3.6 \mathrm{~b}$ & $5.4 \mathrm{~b}$ \\
\hline Metsulfuron & 21 & $6.6 \mathrm{a}$ & $5.3 \mathrm{~b}$ & $4.3 \mathrm{~b}$ & $5.8 \mathrm{ab}$ \\
\hline Trifloxysulfuron & 17 & $6.5 \mathrm{a}$ & $5.1 \mathrm{~b}$ & $4.3 \mathrm{~b}$ & $5.9 \mathrm{ab}$ \\
\hline Foramsulfuron & 29 & $6.6 \mathrm{a}$ & $5.5 \mathrm{~b}$ & $3.8 \mathrm{~b}$ & $5.8 \mathrm{ab}$ \\
\hline Sulfosulfuron & 105 & $6.0 \mathrm{a}$ & $5.3 \mathrm{~b}$ & $3.9 \mathrm{~b}$ & $5.8 \mathrm{ab}$ \\
\hline$\overline{\operatorname{LSD}(0.05)^{\mathrm{c}}}$ & & 0.8 & 1.0 & 1.2 & 0.6 \\
\hline
\end{tabular}

${ }^{a}$ Quality: Taken on a scale of 1 to 9 with 9 being equal to the highest turfgrass quality. Quality ratings of 6 or greater are considered acceptable.

${ }^{\mathrm{b}}$ WAT: Weeks After Treatment.

${ }^{\mathrm{c}}$ Fisher's Least Significant Difference (LSD) at the 0.05 level of probability. 
Table 4-9. Transitional quality ${ }^{\mathrm{a}}$ based on presence of 'QuickTrans' intermediate ryegrass, bermudagrass, and open space. Results were combined over three years (Columbia, MO - 2006, 2007, 2008).

\begin{tabular}{llllll}
\hline Treatment & $\mathrm{g} \mathrm{ai} \mathrm{ha}^{-1}$ & 0 WAT $^{\mathrm{b}}$ & $1 \mathrm{WAT}$ & $3 \mathrm{WAT}$ & $5 \mathrm{WAT}$ \\
\hline Untreated control & - & $7.2 \mathrm{a}$ & $7.1 \mathrm{a}$ & $6.3 \mathrm{a}$ & $6.6 \mathrm{a}$ \\
Chlorsulfuron & 105 & $6.9 \mathrm{ab}$ & $6.3 \mathrm{~b}$ & $3.8 \mathrm{~b}$ & $5.1 \mathrm{~b}$ \\
Rimsulfuron & 35 & $6.9 \mathrm{ab}$ & $6.4 \mathrm{~b}$ & $3.9 \mathrm{~b}$ & $5.3 \mathrm{~b}$ \\
Metsulfuron & 21 & $7.0 \mathrm{ab}$ & $6.4 \mathrm{~b}$ & $3.8 \mathrm{~b}$ & $5.3 \mathrm{~b}$ \\
Trifloxysulfuron & 17 & $7.1 \mathrm{ab}$ & $6.5 \mathrm{~b}$ & $3.9 \mathrm{~b}$ & $5.3 \mathrm{~b}$ \\
Foramsulfuron & 29 & $6.6 \mathrm{~b}$ & $6.1 \mathrm{~b}$ & $4.2 \mathrm{~b}$ & $5.5 \mathrm{~b}$ \\
$\infty$ & 105 & $7.0 \mathrm{ab}$ & $6.3 \mathrm{~b}$ & $4.4 \mathrm{~b}$ & $5.4 \mathrm{~b}$ \\
\hline Sulfosulfuron & & 0.6 & 0.5 & 1.4 & 1.1 \\
\hline LSD $(0.05)^{\mathrm{c}}$ & & &
\end{tabular}

${ }^{\text {a }}$ Quality: Taken on a scale of 1 to 9 with 9 being equal to the highest turfgrass quality. Quality ratings of 6 or greater are considered acceptable.

${ }^{\mathrm{b}}$ WAT: Weeks After Treatment.

${ }^{c}$ Fisher's Least Significant Difference (LSD) at the 0.05 level of probability. 
Table 4-10. One-hundred day recovery date for bermudagrass prior to light and killing frost dates, Columbia, MO (2006, 2007, and 2008).

\begin{tabular}{llllll}
\hline$\frac{\text { Year }}{2006}$ & $\frac{\text { Treatment }}{26 \text { May }}$ & $\frac{5 \text { WAT }^{\mathrm{a}}}{30 \mathrm{June}}$ & $\frac{100 \text { Day }}{8 \text { Oct }}$ & $\frac{\text { Light Frost }^{\mathrm{b}}}{13 \text { Oct }}$ & \\
2007 & 21 May & 25 June & 3 Oct & 28 Oct & 6 Nov \\
2008 & 16 May & 20 June & 28 Sept & 27 Oct & 28 Oct \\
\hline
\end{tabular}

\section{${ }^{a}$ WAT: Weeks After Treatment}

${ }^{\mathrm{b}}$ Light Frost: Temperatures between -2 and 1C for three hours (National Weather Service, 2010).

${ }^{\mathrm{c}}$ Killing Frost: Temperatures below $-2 \mathrm{C}$ for three hours (National Weather Service, 2010). 


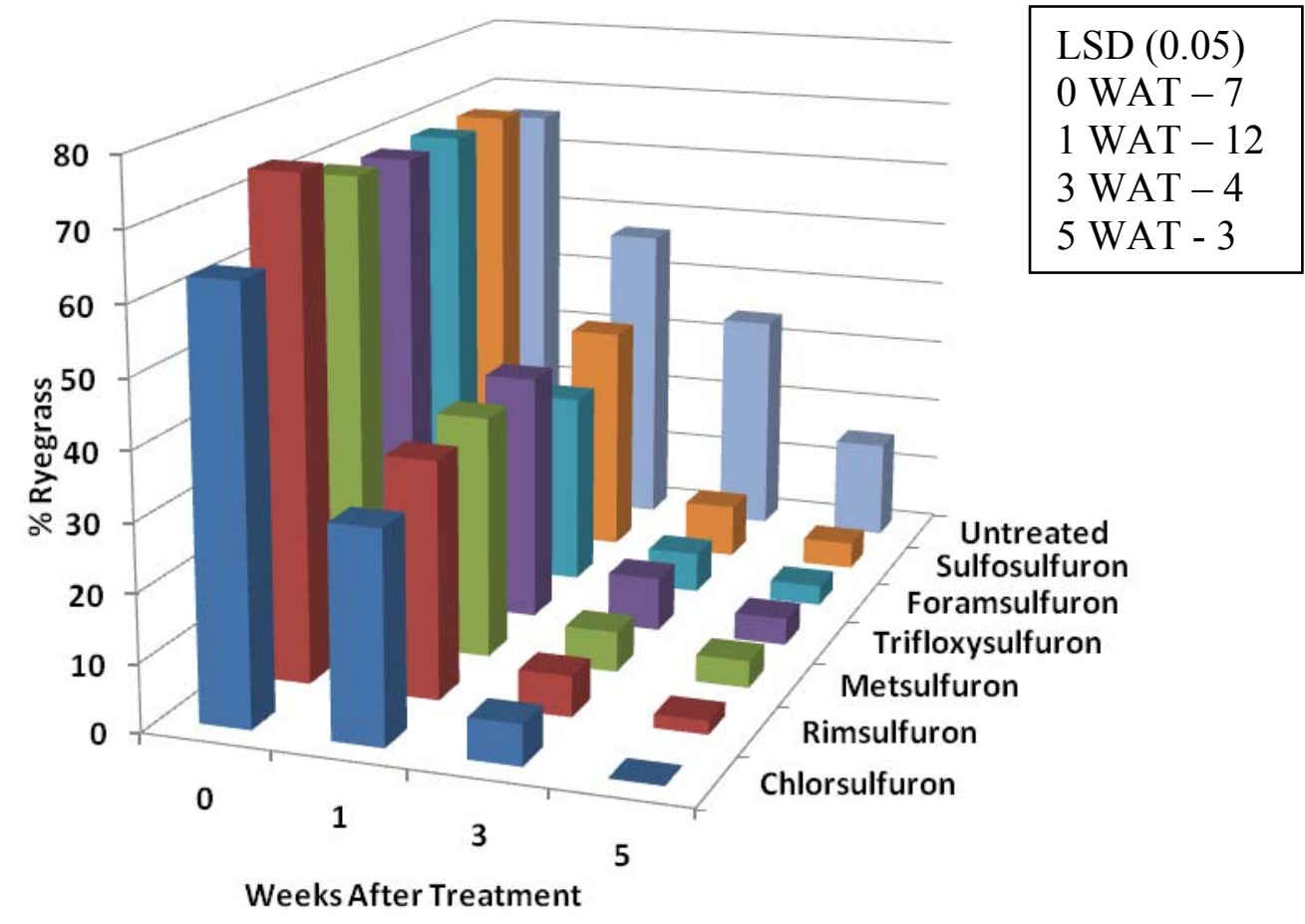

Figure 4-1. Removal of over-seeded 'Brightstar II' perennial ryegrass from bermudagrass treated with sulfonylurea herbicides. Results were combined over three years (Columbia, MO 2006, 2007, 2008). Mean differences were determined using Fisher's Least Significant Difference (LSD) at the 0.05 level of probability. 


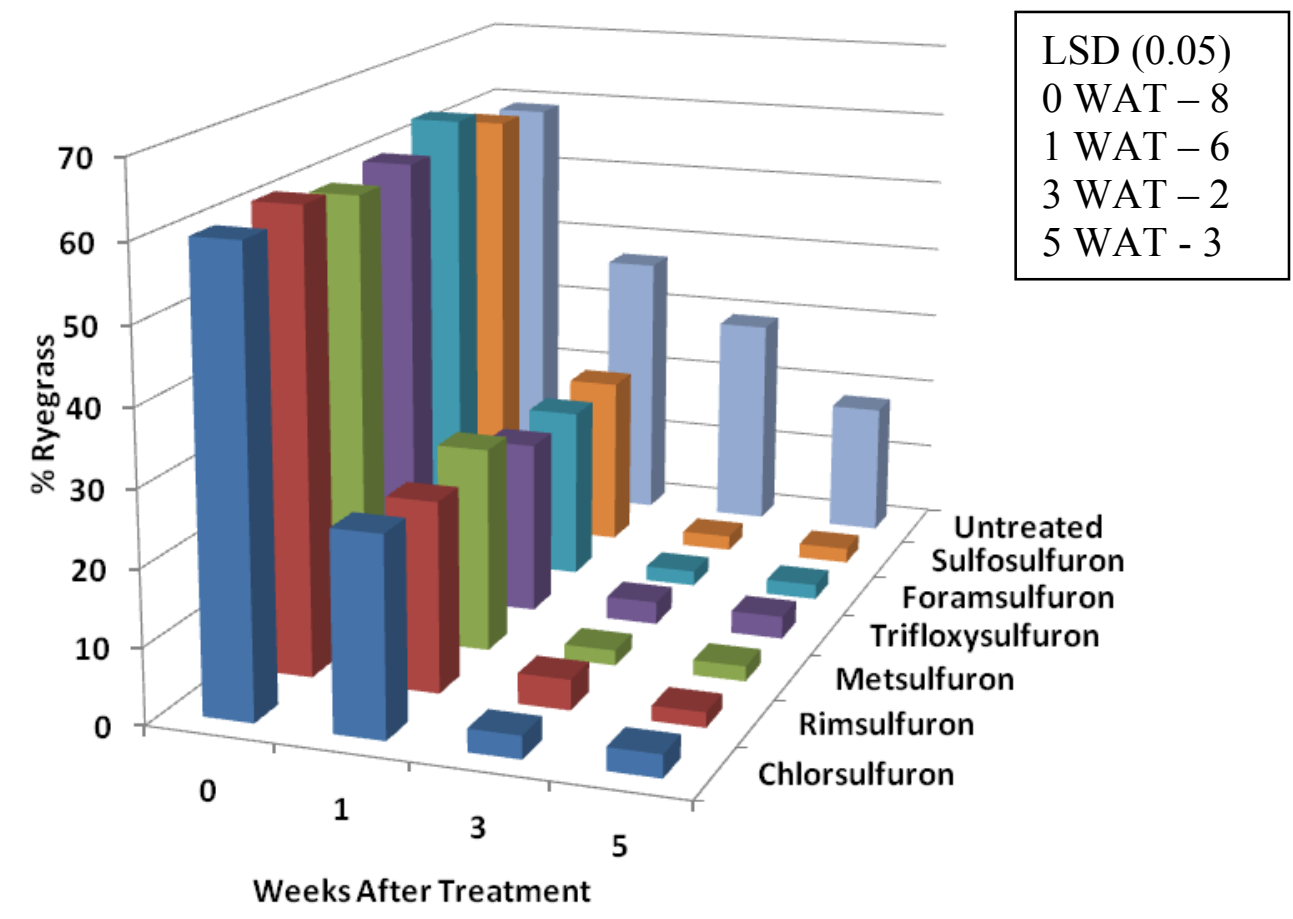

Figure 4-2. Removal of over-seeded 'Evening Shade' perennial ryegrass from bermudagrass treated with sulfonylurea herbicides. Results were combined over three years (Columbia, MO 2006, 2007, 2008). Mean differences were determined using Fisher's Least Significant Difference (LSD) at the 0.05 level of probability. 


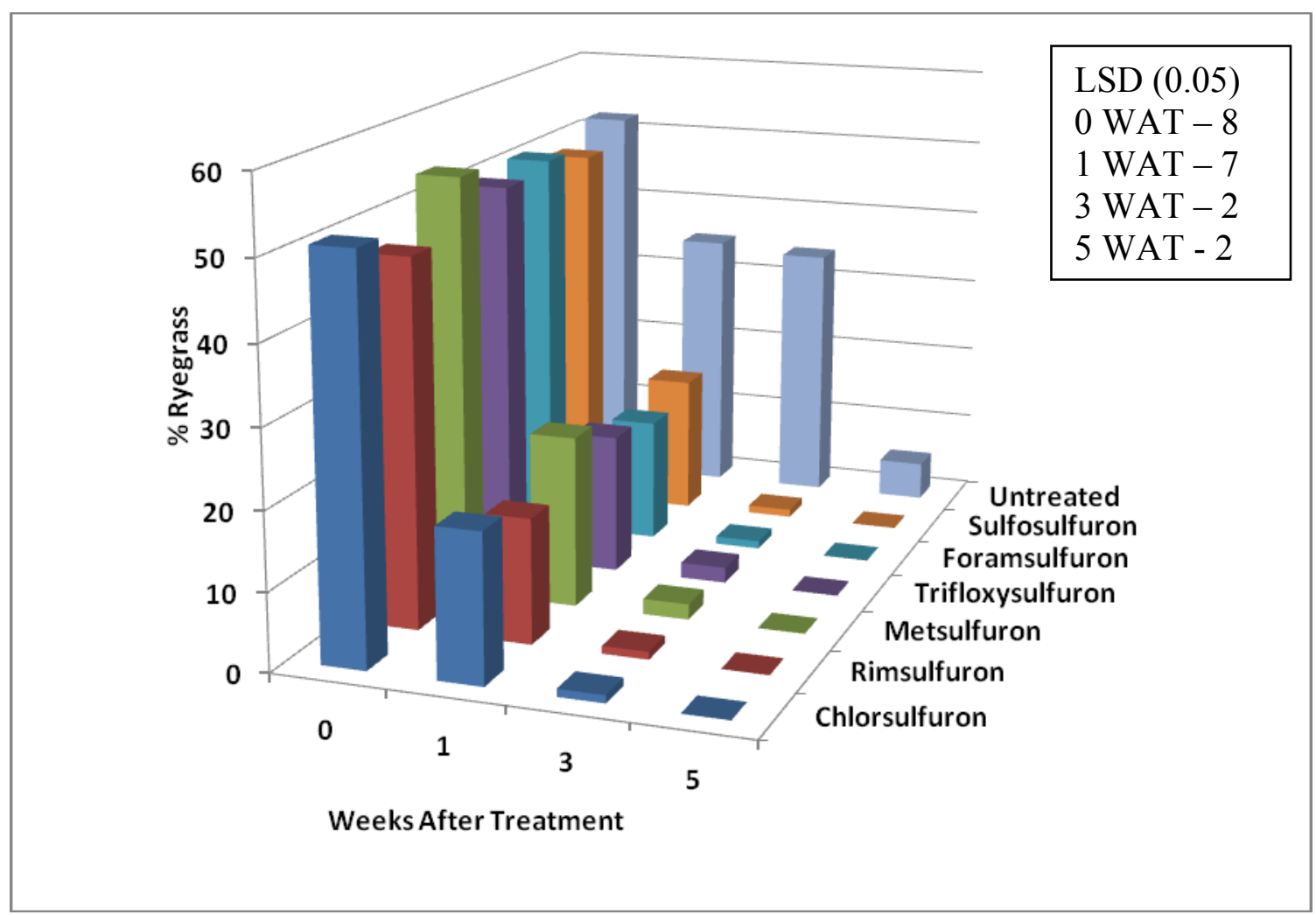

Figure 4-3. Removal of over-seeded 'Transeze' intermediate ryegrass from bermudagrass treated with sulfonylurea herbicides. Results were combined over three years (Columbia, MO - 2006, 2007, 2008). Mean differences were determined using Fisher's Least Significant Difference (LSD) at the 0.05 level of probability. 


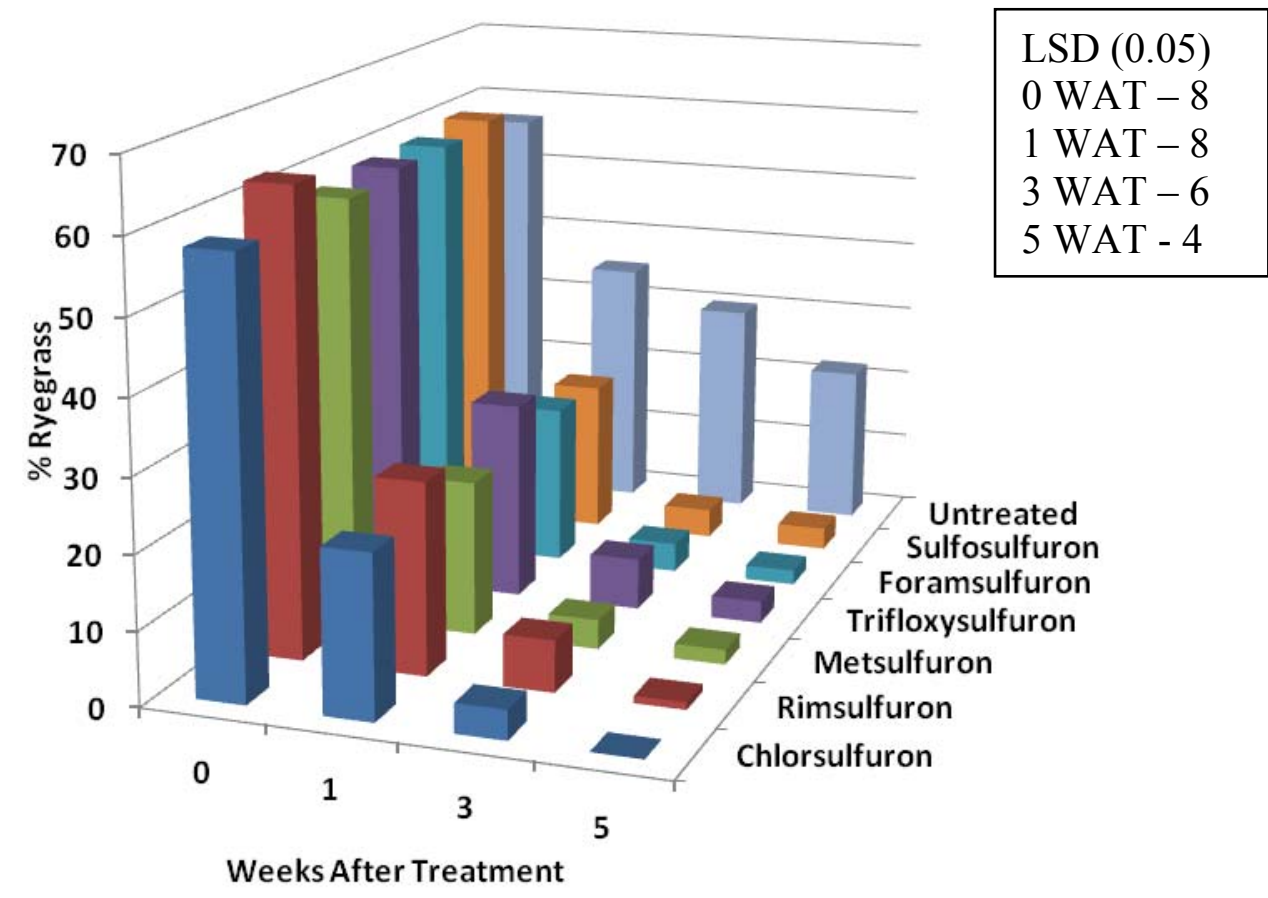

Figure 4-4. Removal of over-seeded 'QuickTrans' intermediate ryegrass from bermudagrass treated with sulfonylurea herbicides. Results were combined over three years (Columbia, MO 2006, 2007, 2008). Mean differences were determined using Fisher's Least Significant Difference (LSD) at the 0.05 level of probability. 


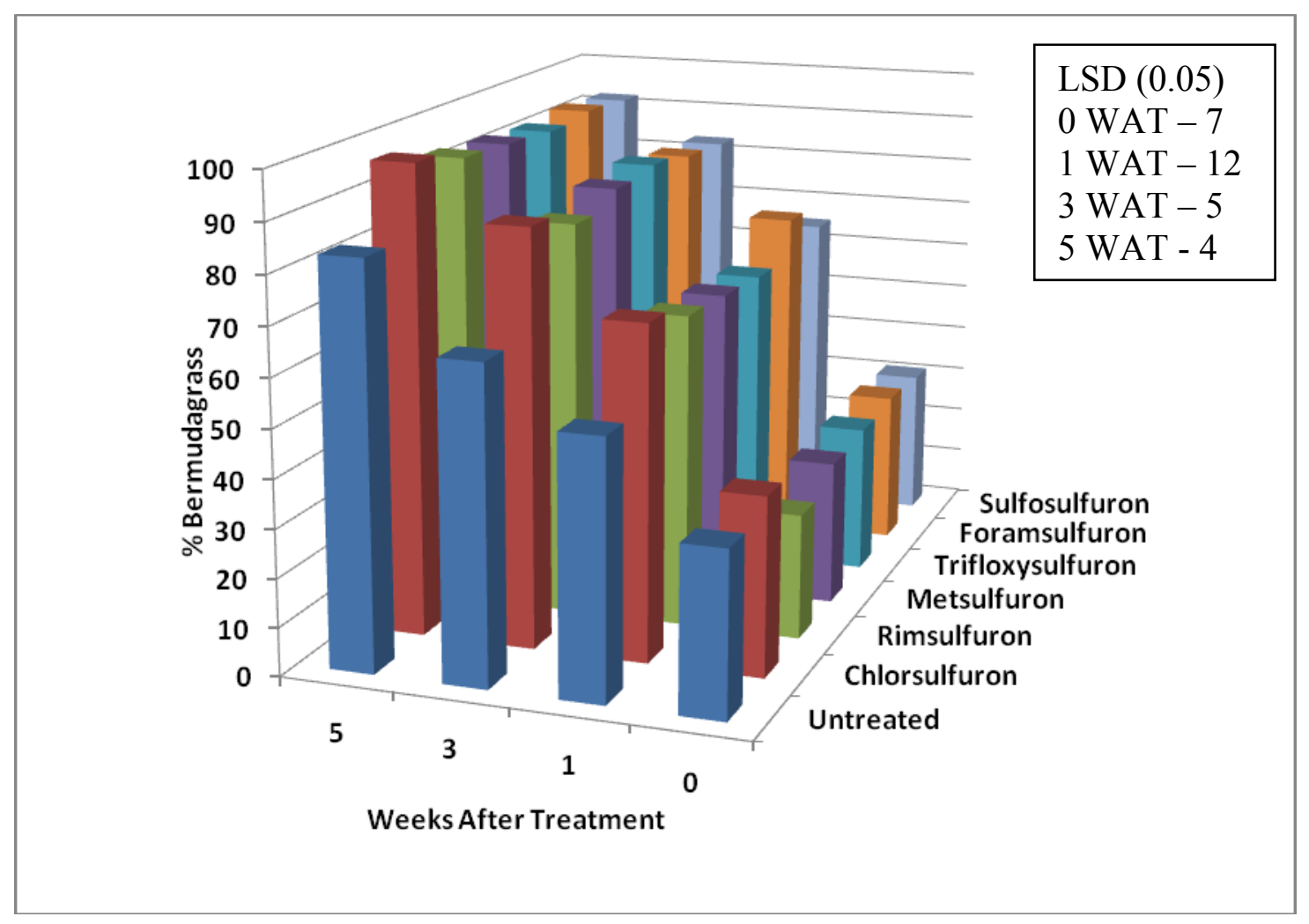

Figure 4-5. Bermudagrass recovery after removal of over-seeded 'Brightstar II' perennial ryegrass treated with sulfonylurea herbicides. Results were combined over three years (Columbia, MO - 2006, 2007, 2008). Mean differences were determined using Fisher's Least Significant Difference (LSD) at the 0.05 level of probability. 


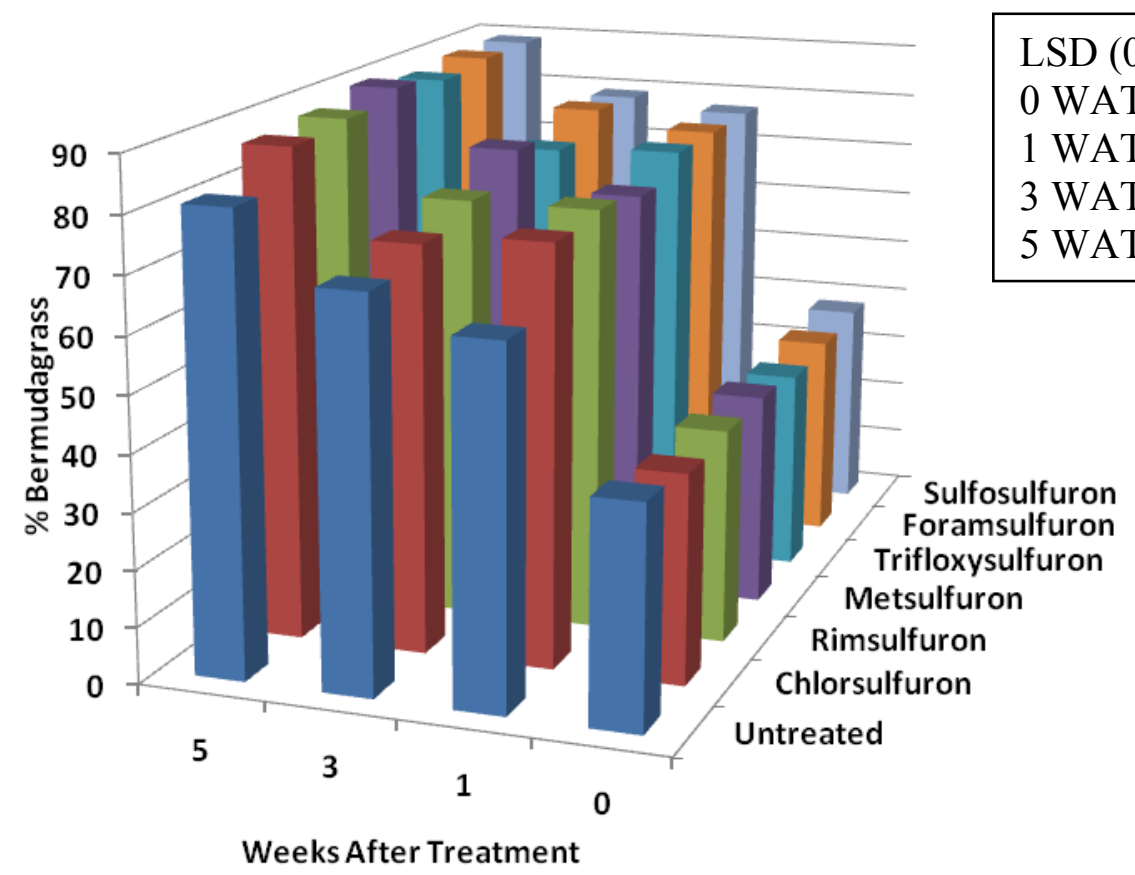

Figure 4-6. Bermudagrass recovery after removal of over-seeded 'Evening Shade' perennial ryegrass treated with sulfonylurea herbicides. Results were combined over three years (Columbia, MO - 2006, 2007, 2008). Mean differences were determined using Fisher's Least Significant Difference (LSD) at the 0.05 level of probability. 


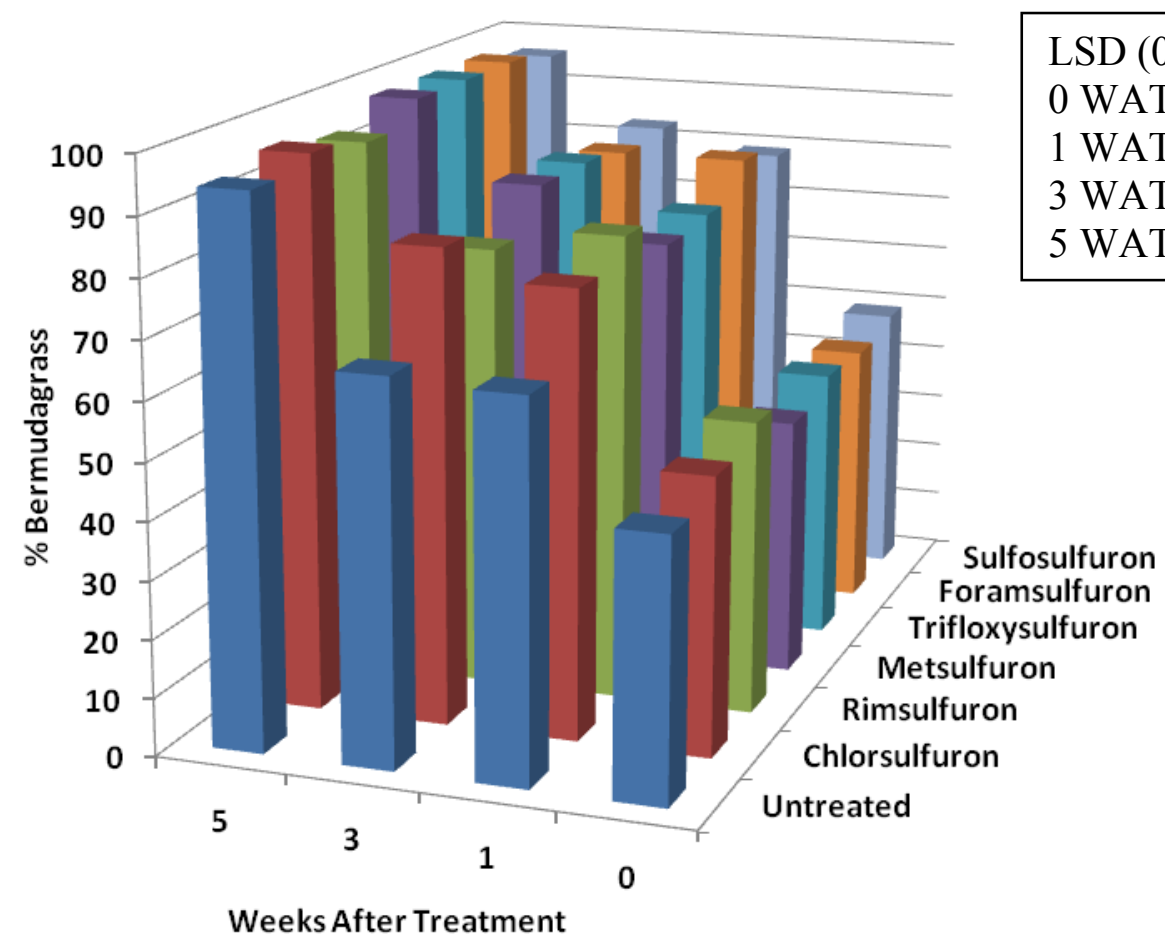

Figure 4-7. Bermudagrass recovery after removal of over-seeded 'Transeze' intermediate ryegrass treated with sulfonylurea herbicides. Results were combined over three years (Columbia, MO - 2006, 2007, 2008). Mean differences were determined using Fisher's Least Significant Difference (LSD) at the 0.05 level of probability. 


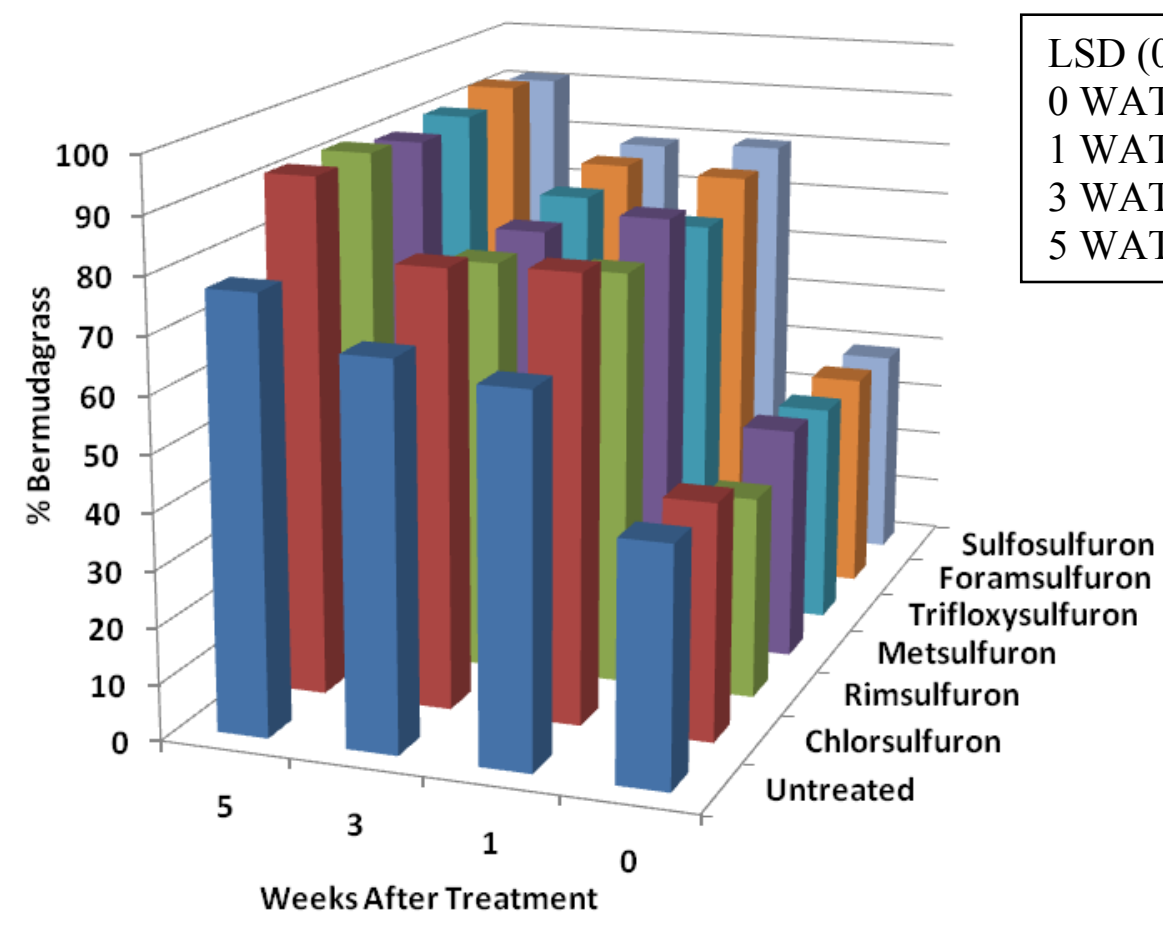

Figure 4-8. Bermudagrass recovery after removal of over-seeded 'QuickTrans' intermediate ryegrass treated with sulfonylurea herbicides. Results were combined over three years (Columbia, MO - 2006, 2007, 2008). Mean differences were determined using Fisher's Least Significant Difference (LSD) at the 0.05 level of probability. 


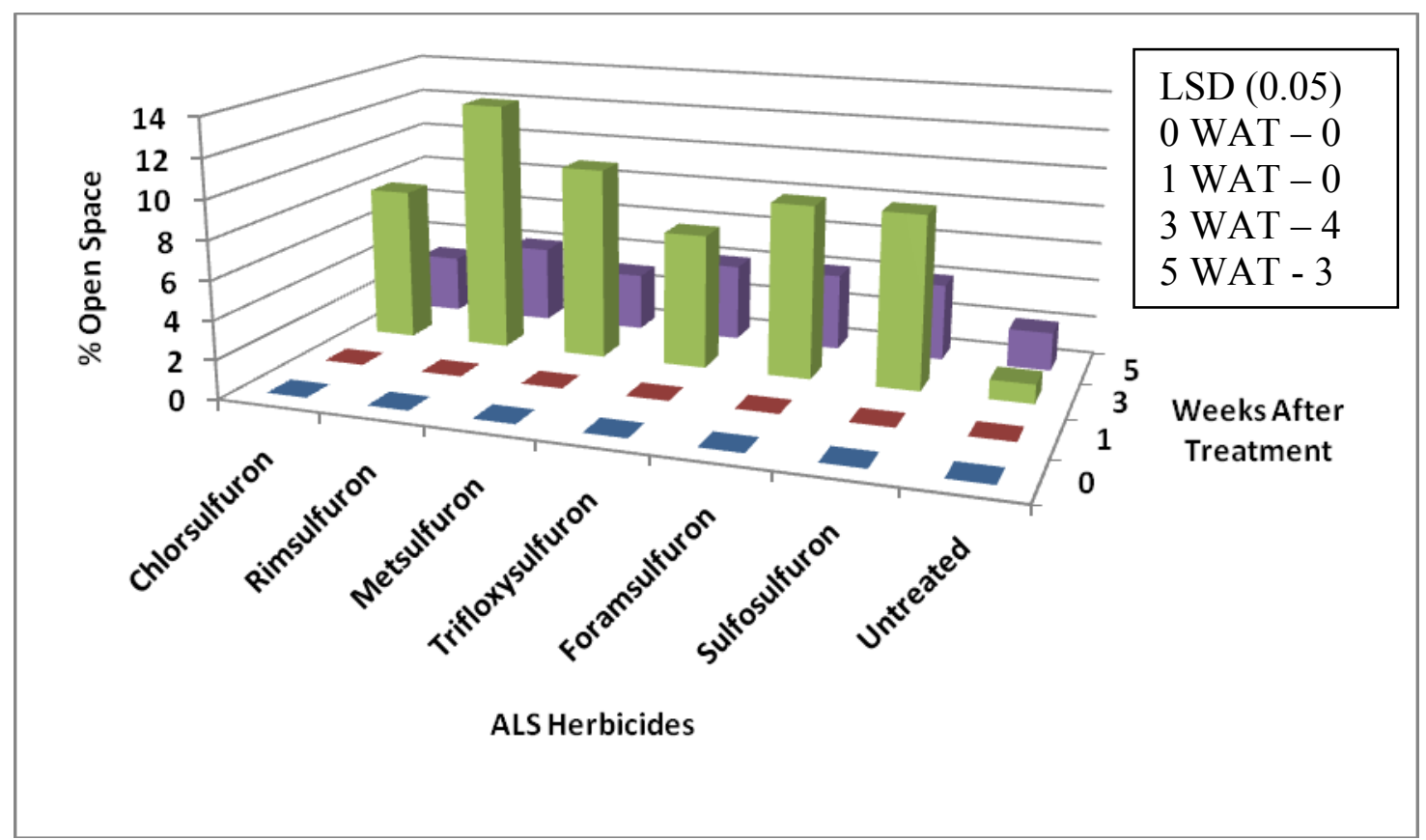

Figure 4-9. Open space created by removal of over-seeded 'Brightstar II' perennial ryegrass from bermudagrass with sulfonylurea herbicides. Results were combined over three years (Columbia, MO - 2006, 2007, 2008). Mean differences were determined using Fisher's Least Significant Difference (LSD) at the 0.05 level of probability. 


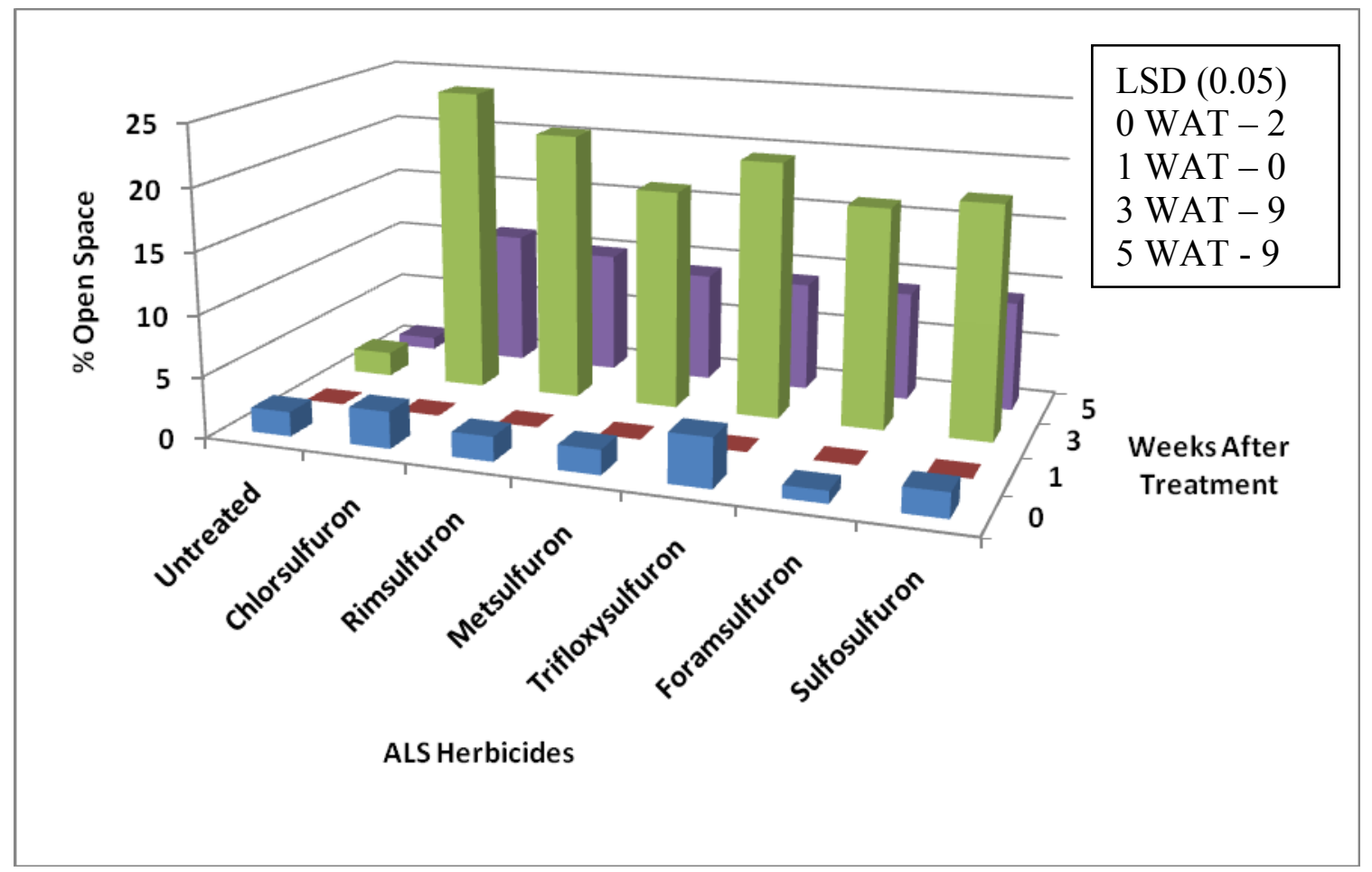

Figure 4-10. Open space created by removal of over-seeded 'Evening Shade' perennial ryegrass from bermudagrass with sulfonylurea herbicides. Results were combined over three years (Columbia, MO - 2006, 2007, 2008). Mean differences were determined using Fisher's Least Significant Difference (LSD) at the 0.05 level of probability. 


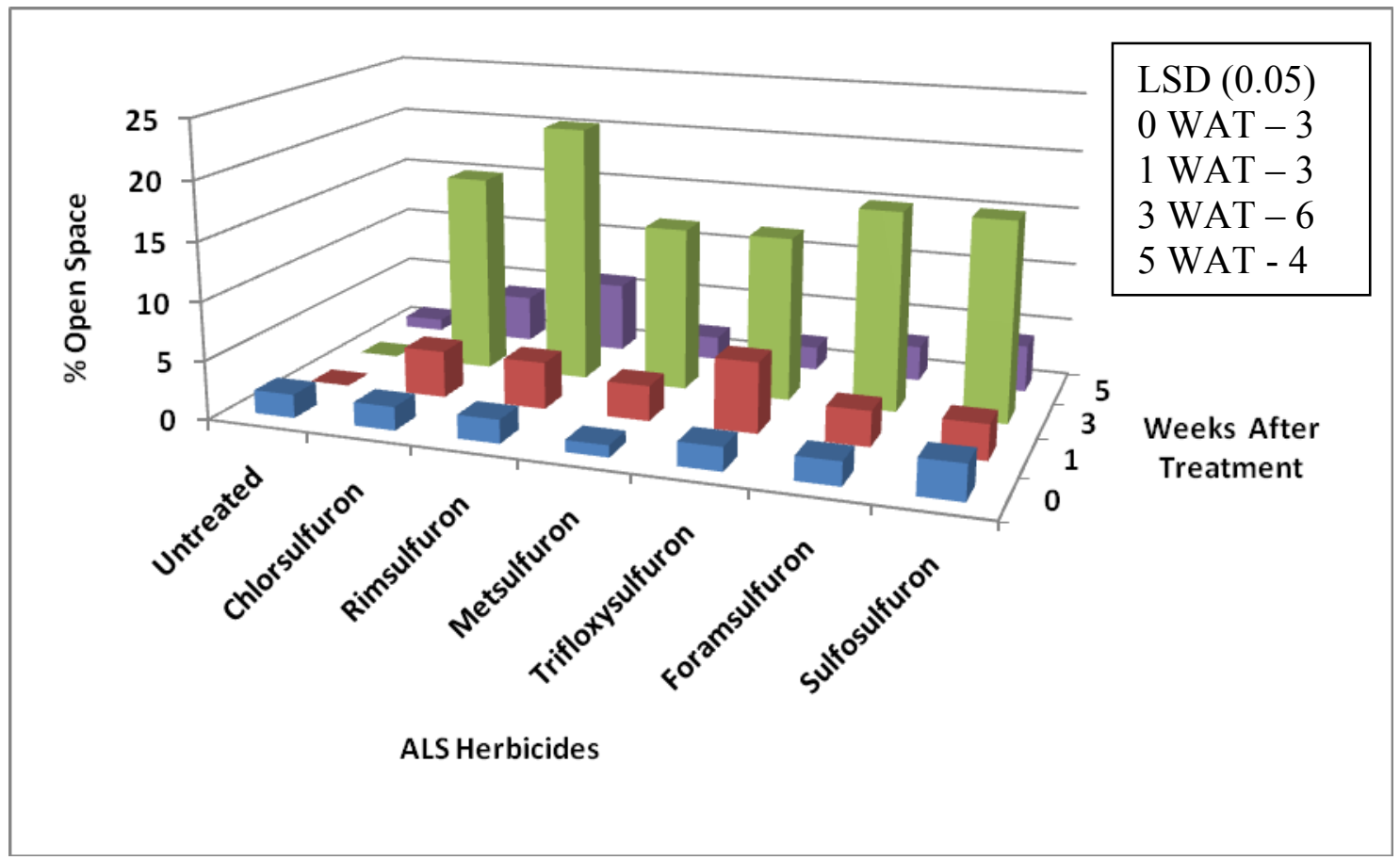

Figure 4-11. Open space created by removal of over-seeded 'Transeze' intermediate ryegrass from bermudagrass with sulfonylurea herbicides. Results were combined over three years (Columbia, MO - 2006, 2007, 2008). Mean differences were determined using Fisher's Least Significant Difference (LSD) at the 0.05 level of probability. 


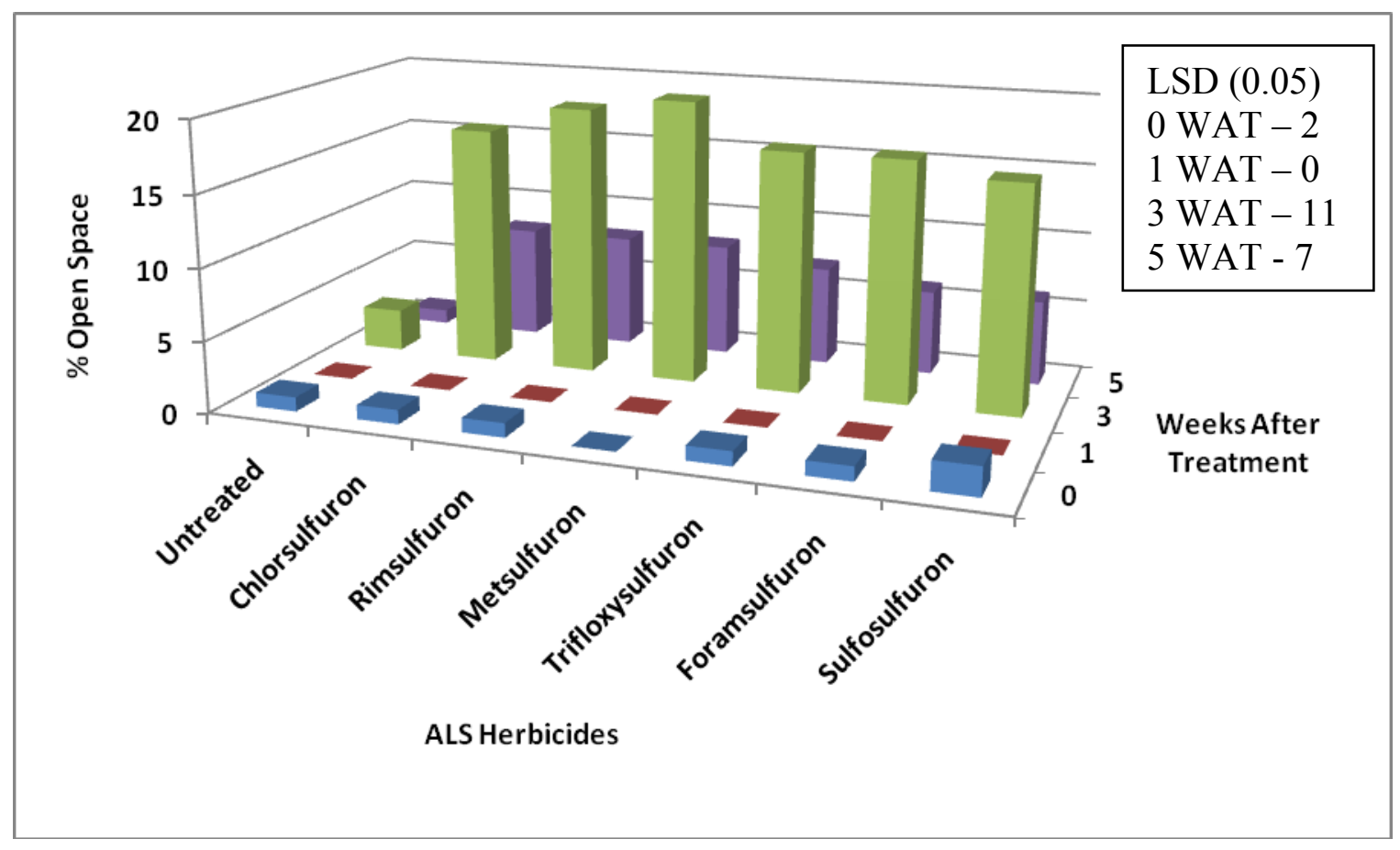

Figure 4-12. Open space created by removal of over-seeded 'QuickTrans' intermediate ryegrass from bermudagrass with sulfonylurea herbicides. Results were combined over three years (Columbia, MO - 2006, 2007, 2008). Mean differences were determined using Fisher's Least Significant Difference (LSD) at the 0.05 level of probability. 


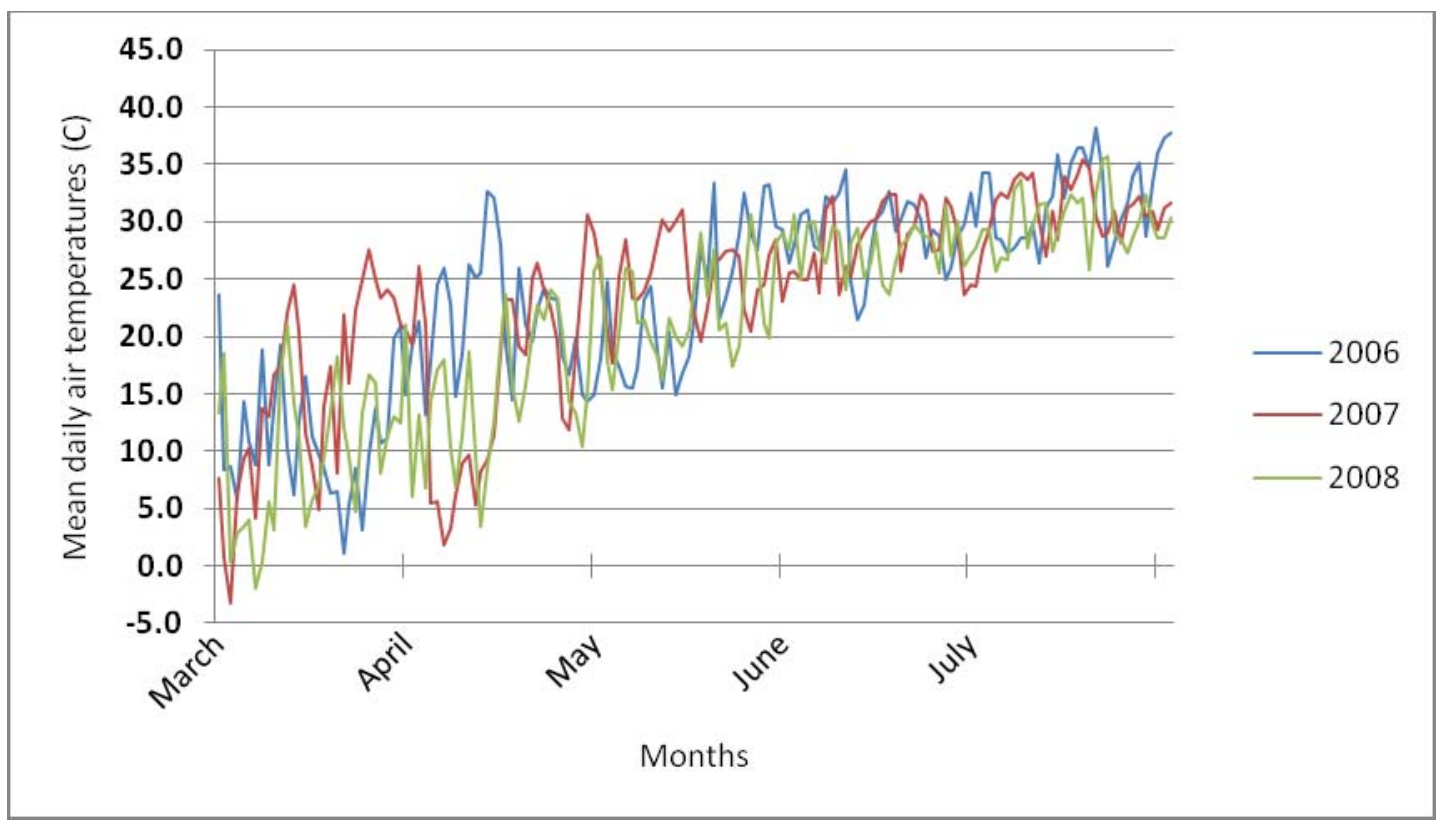

Figure 4-13. Average maximum daily temperatures during spring transition in Columbia, MO. 


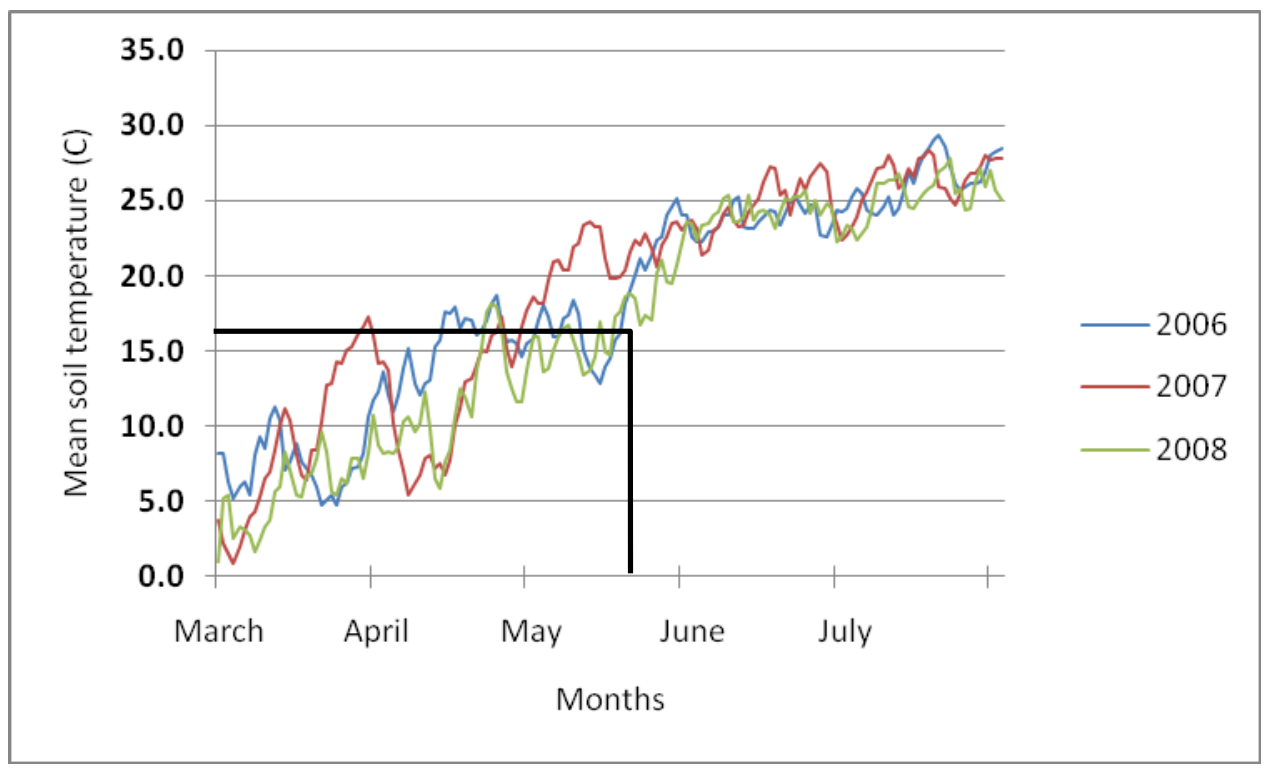

Figure 4-14. Average soil temperatures at $10 \mathrm{~cm}$ in Columbia, MO during spring transition indicating when soil temperatures where consistently above $16.5 \mathrm{C}$ (vertical line). 


\section{VITA}

Brad S. Fresenburg was born May 4, 1954 in St. Louis, Missouri. After attending private schools in St. Louis, he received the following degrees: B.S. in General Agriculture from the University of Missouri at Columbia, Missouri (1976); M.S. in Agronomy from the University of Missouri at Columbia, Missouri (1980); M.B.A. in Management from the University of Missouri at Columbia, Missouri (1990); Ph.D. in Agronomy from the University of Missouri at Columbia, Missouri (2010). He worked eight years (1979 to 1986) as a product development field representative for Sandoz Crop Protection and Velsicol Chemical Corporation. While attending the University of Missouri for his M.B.A. degree, he began work in turfgrass management at the Turfgrass Research Facility in the Department of Horticulture and began work there in 1987. He has been married to the former Carolyn L. Constien of Columbia, Missouri for the past 35 years and has three children, Katherine Lynn Fresenburg, Kimberly Ann Fresenburg and Michael Jason Fresenburg. He is presently a Turfgrass Specialist and member of the Division of Plant Sciences at the University of Missouri, Columbia, Missouri. 